UNIVERSIDADE DE BRASÍLIA

FACULDADE DE CIÊNCIAS DA SAÚDE

CAROLINA MARTINS RIBEIRO

INVESTIGAÇÃO DA ATIVIDADE DO FLUORENO, NAFTALENO, NONILFENOL E PROCIMIDONA SOBRE A ADIPOGÊNESE EM CULTURA DE CÉLULAS

BRASÍLIA 
CAROLINA MARTINS RIBEIRO

\section{INVESTIGAÇÃO DA ATIVIDADE DO FLUORENO, NAFTALENO, NONILFENOL E PROCIMIDONA SOBRE A ADIPOGÊNESE EM CULTURA DE CÉLULAS}

Dissertação apresentada ao Curso de PósGraduação em Ciências Farmacêuticas, da Universidade de Brasília, como requisito parcial à obtenção do Título de Mestre em Ciências Farmacêuticas.

Orientadora: Profa. Dra. Angélica Amorim Amato.

BRASÍLIA 
Autorizo a reprodução e divulgação total ou parcial deste trabalho, por qualquer meio convencional ou eletrônico, para fins de ensino, estudo ou pesquisa, desde que citada a fonte.

Catalogação da Publicação

Ficha catalográfica 
Carolina Martins Ribeiro

INVESTIGAÇÃO DA ATIVIDADE DO FLUORENO, NAFTALENO, NONILFENOL E PROCIMIDONA SOBRE A ADIPOGÊNESE EM CULTURA DE CÉLULAS.

Dissertação de Mestrado apresentada ao Programa de Pós-Graduação em Ciências Farmacêuticas, Faculdade de Ciências da Saúde, Universidade de Brasília, como requisito parcial à obtenção do título de Mestre em Ciências Farmacêuticas.

Aprovada em de de 2015 .

\section{Banca Examinadora}

Profa. Dra. Angélica Amorim Amato - Universidade de Brasília

Profa. Dra. Maria de Fátima Borin - Universidade de Brasília

Profa. Dra. Michella Soares Coêlho - Universidade de Brasília 
Dedico esse trabalho a Deus, aos meus pais, Eustáquio e Candida, e a minha irmã, Juliana, que mesmo distantes, estavam sempre me apoiando e incentivando. E ao meu querido amigo Willian por me acolher em seu lar. 


\section{AGRADECIMENTOS}

Agradeço a Deus, força maior e invisível, que se fez sempre presente em meu caminho, me auxiliando e suprindo minhas necessidades.

Agradeço a Capes (Coordenação de Aperfeiçoamento de Pessoal de Nível Superior) pela bolsa cedida durante esses dois anos de mestrado. Ao Laboratório de Farmacologia Molecular (FarMol) da Faculdade de Saúde - UnB pelo espaço e estrutura física para realização dos experimentos.

Às secretárias da pós-graduação, Íris e Kirla, por estarem sempre dispostas a nos atender e a nos ajudar.

Ao grande exemplo de orientadora, professora e profissional, Angélica Amorim Amato pela oportunidade, pela paciência e pelos ensinamentos.

Aos meus pais, Eustáquio e Candida que sempre me ensinaram o valor e a importância dos estudos na minha vida, e não mediram esforços para tornar possível a concretização de mais essa etapa. A minha irmã, Juliana pelo apoio e pelo carinho. Aos meus avôs, Tobias e Maria, e a minha prima Daniela, pelas orações e pelas palavras de incentivo. Agradeço a todos meus familiares pela força e incentivo. Amo vocês!

Ao meu grande amigo Willian Damasceno (Prefeito) pela generosidade e por me ceder seu lar para se tornar meu lar.

Agradeço aos colegas e professores do FarMol pelas conversas, aprendizados e paciência. Agradeço em especial: ao meu conjunto e amiga, Nady, que juntas compartilhamos aprendizados, ensinamentos, sorrisos e fizemos esse trabalho acontecer; a minha irmã do Piauí, Fernanda, pelo carinho, pelo cuidado, pela paciência, pelos ensinamentos e pela irmandade; a futura Duquesa de Arinos, Cinthia, pelos conselhos e pelas melhores risadas; ao exemplo de sinceridade e de pós-graduanda, Mariella, pelo seu talento e dom de explicar e ensinar; ao Sidney, pelo seu otimismo, inteligência e ensinamento; e a todos que ajudaram na realização desse trabalho. 
À Rilva e aos estagiários pela paciência, pela ajuda e por nos mostrar onde encontrar qualquer coisa no FarMol. Aos PIBICs, Carol Taveira (saudades eternas... "um anjinho no céu”), Alana e Kenzo pela ajuda e pelo esforço.

Aos amigos que fiz aqui em Brasília, os quais fiz deles uma família, Lari, Lay, Nay, Natália, Weverton, Marcel, Dudu, Tamyres, Ruy, Marlla, Alê, Camila, Michelle, Kátia, Clarissa, pela companhia e pelos momentos de distração.

Aos amigos de Minas Gerais que compreenderam minha ausência e sempre me apoiaram. Em especial às minhas queridas, Laís e Renata pelas dicas e incentivo.

Enfim, a todos que colaboraram para a realização desse trabalho, os meus sinceros agradecimentos. 
"A mente que se abre a uma nova ideia jamais voltará ao seu tamanho original."

(Albert Einstein) 


\section{RESUMO}

A obesidade e suas complicações são observadas com frequência crescente e em idades cada vez mais precoces. O aumento de síndromes relacionadas ao excesso de peso pode estar relacionado com as recentes mudanças na alimentação, no estilo de vida e/ou no meio ambiente. Entre os fatores ambientais, destaca-se o papel de contaminantes ambientais capazes de atuar como desreguladores endócrinos (DEs). A atividade dos DEs pode ocorrer por vários mecanismos, e um mecanismo bem caracterizado é a atuação sobre os receptores nucleares. O fluoreno, o naftaleno, o nonilfenol e a procimidona são contaminantes ambientais caracterizados como DEs e a que a população está em constante exposição. Com o objetivo de investigar a capacidade obesogênica desses compostos, foi avaliada a sua atividade sobre dois receptores chave da adipogênese, o receptor gama ativado por proliferadores peroxissomais (PPAR $\gamma$ ) e receptor alfa de glicocorticoide $(\mathrm{GR} \alpha)$, por meio do ensaio de gene repórter. Foi avaliado também seu potencial adipogênico em cultura de células, em pré-adipócitos murinos 3T3-L1 e em células mesenquimais murinas C3H10T1/2, tratados durante 10 dias com os DEs, desde o período da indução da diferenciação adipocitária, e avaliados quanto ao acúmulo lipídico intracelular ou a expressão do RNAm do gene que codifica a proteína ligadora de ácidos graxos adipocitária, um marcador de adipócito maduro. Nenhum dos DEs investigados apresentou efeito sobre a atividade transcricional do PPAR $\gamma$ ou GR $\alpha$. Foi observado baixo potencial adipogênico do nonilfenol em pré-adipócitos 3T3-L1 induzidos a se diferenciar com meio completo (inibidor de fosfodiesterase, dexametasona e insulina) ou meio incompleto (insulina), e baixo potencial adipogênico do fluoreno, naftaleno e procimidona em pré-adipócitos 3T3-L1 induzidos a se diferenciar com meio incompleto. Estes dados sugerem o baixo potencial adipogênico dos quatro compostos estudados, por vias independentes da ação do PPAR $\gamma$ ou GR $\alpha$.

Palavras chave: obesidade, desreguladores endócrinos, receptor gama ativado por proliferadores peroxissomais, receptor de glicocorticoide, fluoreno, naftaleno, nonilfenol, procimidona. 


\begin{abstract}
Obesity and its complications are observed with increasing frequency and at younger ages. The increase in the incidence of overweight-related syndromes may be associated with the recent changes in diet, lifestyle and/or the environment. Among the environmental factors, are environmental contaminants able to act as endocrine disruptors (EDs). EDs can act by several mechanisms, and one of their well-characterized actions is on nuclear receptors. Fluorene, naphthalene, nonylphenol and procymidone are environmental contaminants characterized as EDs and to which the population is constantly exposure. In order to investigate the obesogenic activity of these compounds, we investigated their action on two adipogenesisrelated nuclear receptors, peroxisome proliferator-activated gamma (PPAR $\gamma$ ) and glucocorticoid receptor alpha $(\mathrm{GR} \alpha)$, by reporter gene assays. We also evaluated their adipogenic activity in cell culture, using both 3T3-L1 murine preadipocytes cells and C3H10T1/2 murine mesenchymal cells, treated for 10 days with the EDs, since the period of adipocyte differentiation induction. Adipogenesis was assessed by intracellular lipid accumulation and by the expression of adipocyte fatty acid binding protein gene transcript, which is a marker of mature adipocytes. None of EDs investigated affected the transcriptional activity of PPAR $\gamma$ or GR $\alpha$. Nonylphenol had a weak adipogenic activity in 3T3-L1 preadipocytes induced to differentiate in complete medium (phosphodiesterase inhibitor, insulin and dexamethasone) or incomplete medium (insulin), whereas fluorene, naphthalene and procymidone exhibited weak adipogenic activity in 3T3-L1 preadipocytes induced to differentiate with incomplete medium. Taken together, these data suggest that the four DEs investigated have a low adipogenic potential by PPAR $\gamma$ or GR $\alpha$-independent pathways.
\end{abstract}

Keywords: obesity, endocrine disruptors, activated receptor gamma peroxisome proliferator, glucocorticoid receptor, fluorene, naphthalene, nonylphenol, procymidone. 


\section{LISTA DE ILUSTRAÇÕES}

Figura 1 - Fontes e vias de exposição, alvos metabólicos e consequências fisiopatológicas dos DEs

Figura 2 - Indução da diferenciação de pré-adipócitos em adipócitos maduros pelos

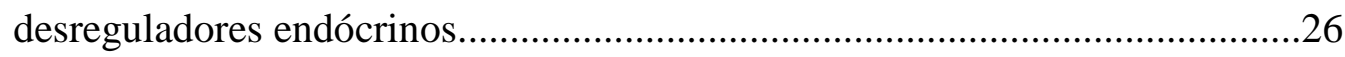

Figura 3 - Estrutura química do fluoreno e do naftaleno................................................. 29

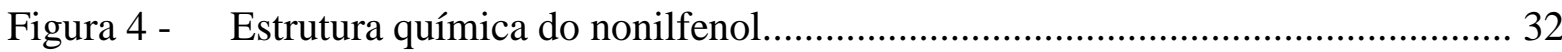

Figura 5 - Estrutura química da procimidona, pertencente à família de fungicidas

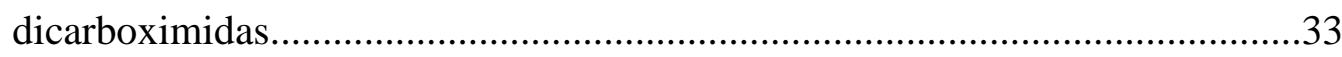

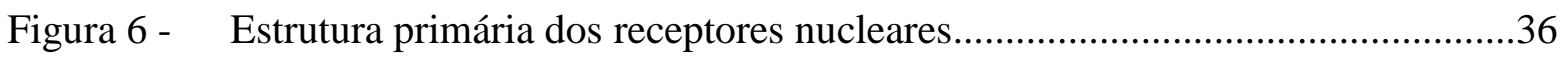

Figura 7 - Receptor nuclear na sua forma inativa (não ligada), interagindo com complexos correpressores, e ativa (ligada), interagindo com coativadores (parte

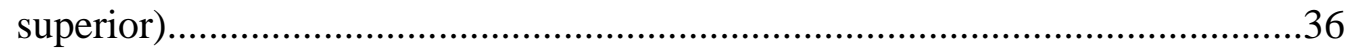

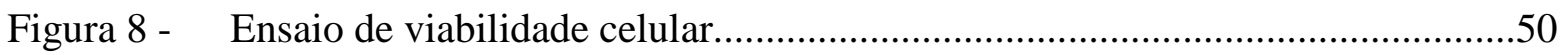

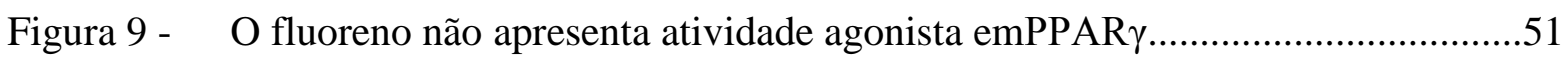

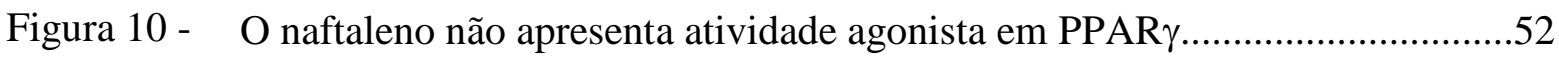

Figura 11 - O nonilfenol não apresenta atividade agonista em PPAR $\gamma$..............................52

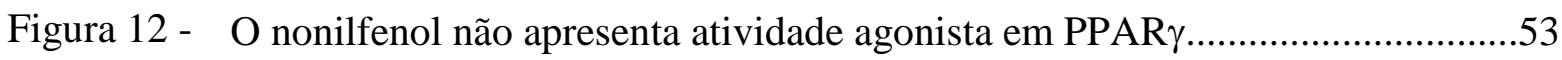

Figura 13 - O naftaleno, nonilfenol e procimidona não apresentam atividade antagonista

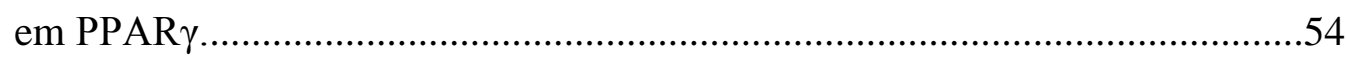

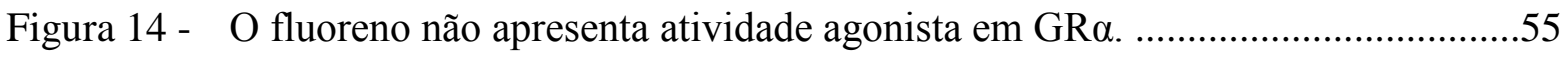

Figura 15 - O naftaleno não apresenta atividade agonista em GR $\alpha$..................................55

Figura 16 - O nonilfenol não apresenta atividade agonista em GR $\alpha$.................................56

Figura 17 - A procimidona não apresenta atividade agonista em GR $\alpha$.......................................56

Figura 18 - Efeito do fluoreno sobre a adipogênese em células mesenquimais

C3H10T1/2.

Figura 19 - Efeito do naftaleno sobre a adipogênese em células mesenquimais

$\mathrm{C} 3 \mathrm{H} 10 \mathrm{~T} 1 / 2$

Figura 20 - Efeito do nonilfenol sobre a adipogênese em células mesenquimais 
Figura 21 - Efeito da procimidona sobre a adipogênese em células mesenquimais C3H10T1/2.

Figura 22 - Efeito do fluoreno sobre a adipogênese em pré-adipócitos 3T3-L1 induzidos a se diferenciar em adipócitos com meio completo.

Figura 23 - Efeito do naftaleno sobre a adipogênese em pré-adipócitos 3T3-L1 diferenciar em adipócitos com meio completo

Figura 24 - Efeito do nonilfenol sobre a adipogênese em pré-adipócitos 3T3-L1 diferenciar em adipócitos com meio completo.

Figura 25 Efeito da procimidona sobre a adipogênese em pré-adipócitos 3T3-L1

induzidos a se diferenciar em adipócitos com meio completo.

Figura 26 Efeito do fluoreno sobre a adipogênese em pré-adipócitos 3T3-L1 induzidos a se diferenciar com meio incompleto.

Figura 27 - Efeito do naftaleno sobre a adipogênese em pré-adipócitos 3T3-L1 induzidos a se diferenciar com meio incompleto .65

Figura 28 Efeito do nonilfenol sobre a adipogênese em pré-adipócitos 3T3-L1 induzidos a se diferenciar com meio incompleto.

Figura 29 - Efeito da procimidona sobre a adipogênese em pré-adipócitos 3T3-L1 induzidos a se diferenciar com meio incompleto.

Figura 30 - Expressão relativa de Fapba em células mesenquimais $\mathrm{C} 3 \mathrm{H} 10 \mathrm{~T} 1 / 2$

Figura 31 - Expressão relativa de Fapba em células 3T3-L1 


\section{LISTA DE TABELAS}

Tabela 1 - $\quad$ Fonte de exposição e efeitos desreguladores endócrinos do fluoreno, naftaleno, nonilfenol e procimidona...........................................................35

Tabela 2 - $\quad$ Descrição da massa molecular e do fabricante dos reagentes utilizados neste estudo. .35

Tabela 3 - Sequência dos primers utilizados na PCR em tempo

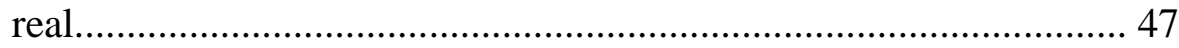




\section{LISTA DE ABREVIATURAS E SIGLAS}

$3 \mathrm{MC}$

$\mathrm{AMP}_{\mathrm{C}}$

aP2 ou FABP

APEs

AR

ARKO

BPA

$\mathrm{C} / \mathrm{EBP} \alpha$

$\mathrm{C} / \mathrm{EBP} \beta$

$\mathrm{C} / \mathrm{EBP} \delta$

Cox 2

DBD

DDT

DEHP

DEMEM

DEPC

DEs

DES

DHT

DMBA

DMSO

DNA

DR1

$\mathrm{ERR} \alpha$

ER- $\beta$

Fabpa

FAS

$\mathrm{FSH}$

FSHR 3-metilcolantreno

adenosina 3', 5' -monofosfato cíclico

proteína ligadora de ácidos graxos

etoxilatos de alquifenois, alkylphenol ethoxylates

receptor de androgênio

deleção homozigota (knockout) do receptor de androgênio

bisfenol A

proteína alfa de ligação ao acentuador CCAAT

proteína beta de ligação ao acentuador CCAAT

proteína delta de ligação ao acentuador CCAAT

cicloxigenase tipo 2

domínio de ligação ao DNA

dicloro-difenil-tricloroetano

ftalatos de di-2-etilexila

Dulbecco's Modified Eagle Medium

dicarbonato de dietila

desreguladores Endócrinos

Dietilestilbestrol

Diidrotestosterona

7,12-dimetilbenz[a]antraceno

Dimetilsulfóxido

ácido desoxirribonucleico

repetições diretas da sequência consenso AGGTCA separadas por um único nucleotídeo

receptores alfa relacionado ao estrogênio

receptor de estrogênio beta

proteína ligadora de ácidos graxos adipocitária

sintase de ácido graxo

hormônio folículo estimulante

receptor hormônio folículo estimulante 
FXR

GAL4

$\mathrm{GAL}_{5 \mathrm{x}}-\mathrm{Luc}$

GLUT-4

GR

GRE-Luc

$\mathrm{GR} \alpha$

GR $\beta$

HPA

$H s p$

IBMX

IL-1

IL-2

IL-6

IMC

IPCS

LBD

LBDPPAR $\gamma$ -

DBDGAL4

LH

LXR

MCP-1

MTT

NHANES

NPE

OMS

PAHs

PBDE

PBS

PCBs receptor farsenoide $\mathrm{X}$

fator de transcrição de leveduras

um plasmídeo contendo a sequência do repórter luciferase dirigida por 5 cópias do elemento responsivo ao GAL4

transportador de glicose tipo 4

receptor de glicocorticoide

construção contendo o gene repórter luciferase dirigido pelo elemento responsivo ao GR

receptor de glicocorticoide-alfa

receptor de glicocorticoide-beta

hipotálamo-pituitária-adrenal

heat shock proteins

Isometilbutilxantina

interleucina-1

interleucina-2

interleucina-6

índice de massa corpórea

International Programme on Chemical Safety

domínio de ligação ao ligante

vetor quimérico contendo o LBD do PPAR $\gamma$ fusionado ao DBD do

fator de transcrição de leveduras GAL4

hormônio luteinizante

receptores $\mathrm{X}$ do fígado

proteína quimiotática de monócito

brometo de 3-(4,5-dimetiltiazol-2-yl)-2,5-difeniltetrazolio

National Health and Nutrition Examination Survey

etoxilato de nonilfenol

Organização Mundial de Saúde

hidrocarbonetos aromáticos policíclicos, polycyclic aromatic

hydrocarbon

éter difenil polibromado

salina tamponada com fosfato, phosphate buffered saline

Bifenilos policlorados 
PCR

PEPCK

PPARs

PPAR $\alpha$

$\mathrm{PPAR} \beta / \delta$

PPAR $\gamma$

PR

RNA

RNAm

RXRs

SCD1

SNC

SREBP-1c

$\mathrm{T}_{3}$

$\mathrm{T}_{4}$

TBE

TBT

TCDD

TNF- $\alpha$

TR

TSH

UV

Vigitel

$\alpha$ ERKO reação de polimerase em cadeia

fosfoenolpiruvato carboxiquinase

receptores ativados por proliferadores peroxissomais

receptores ativados por proliferadores peroxissomais-alfa

receptores ativados por proliferadores peroxissomais-beta/delta

receptores ativados por proliferadores peroxissomais-gama

receptor de progesterona

ácido ribonucleico

ácido ribonucleico mensageiro

receptores retinoide $X$

estearoil-CoA dessaturase-1

sistema nervoso central

proteína ligadora do elemento regulado por esteroides 1c

Triiodotironina

Tiroxina

tris/borato/EDTA

Tributilestanho

2,3,7,8-tetraclorodibenzo-p-dioxina

fator de necrose tumoral-alfa

receptor de hormônio tireoidiano

hormônio estimulante da tireoide

Ultravioleta

Sistema de Vigilância de Fatores de Risco e Proteção para Doenças

Crônicas por Inquérito Telefônico

deleção homozigota (knockout) do receptor alfa de estrogênio 


\section{LISTA DE UNIDADES DE MEDIDA}

$\begin{array}{ll}\mathrm{kg} / \mathrm{m}^{2} & \text { quilograma por metro cúbico } \\ \mathrm{nM} & \text { Nanomolar } \\ \mathrm{U} / \mathrm{mL} & \text { unidades por mililitros } \\ \mu \mathrm{g} / \mathrm{mL} & \text { microgramas por mililitros } \\ \mathrm{M} & \text { Molar } \\ \mu \mathrm{L} & \text { Microlitros } \\ \mathrm{nm} & \text { Nanómetro } \\ \mathrm{ng} & \text { Nanogramas } \\ \mu \mathrm{M} & \text { Micromolar } \\ \mathrm{mL} & \text { Mililitros } \\ \mathrm{rpm} & \text { rotações por minuto } \\ \mathrm{mg} / \mathrm{mL} & \text { miligramas por mililitro }\end{array}$




\section{SUMÁRIO}

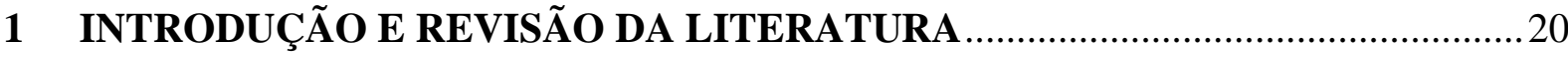

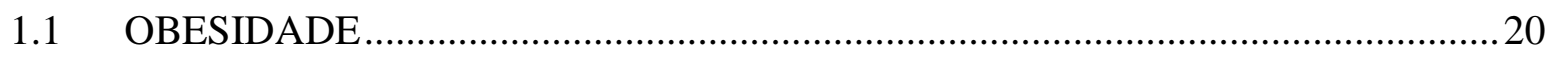

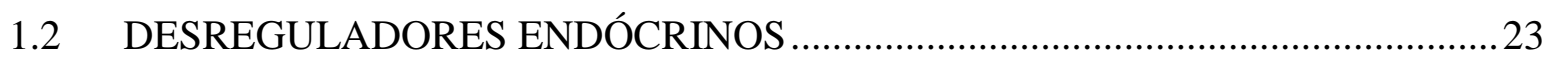

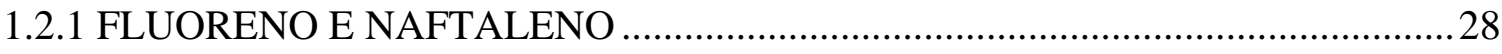

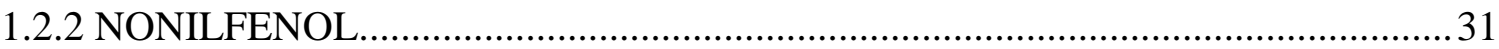

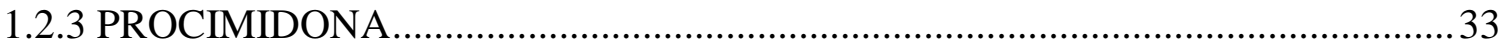

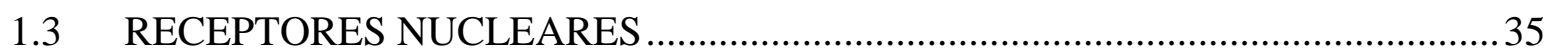

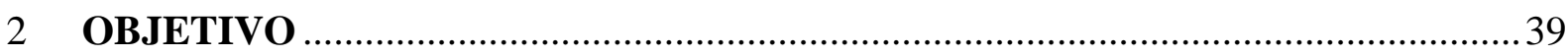

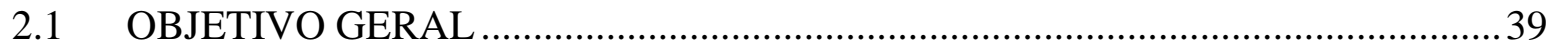

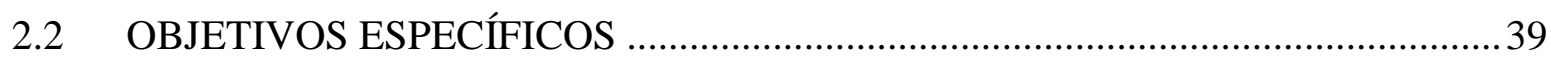

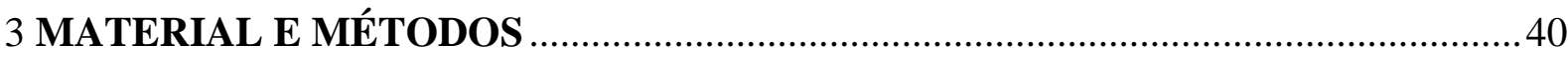

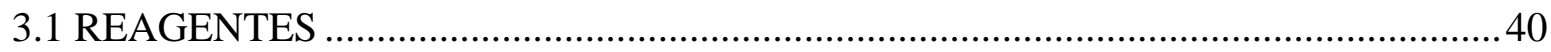

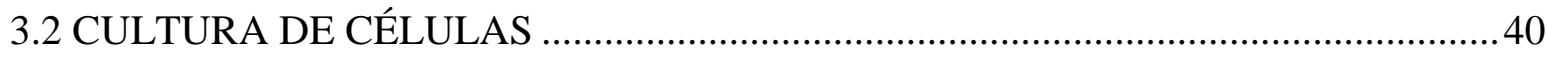

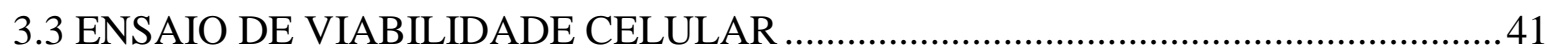

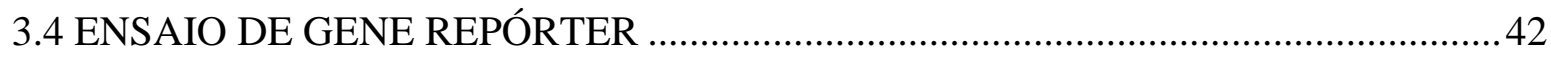

3.5 ENSAIO DE ADIPOGÊNESE EM CULTURA DE CÉLULAS ................................ 44

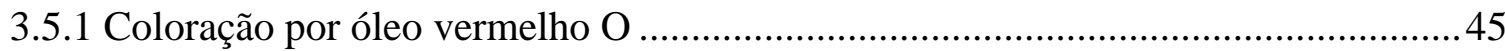

3.5.2 Avaliação da expressão do RNAm da FABP-A ..................................................... 46

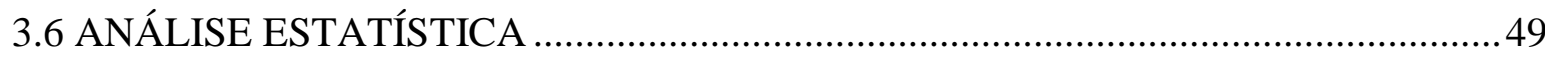

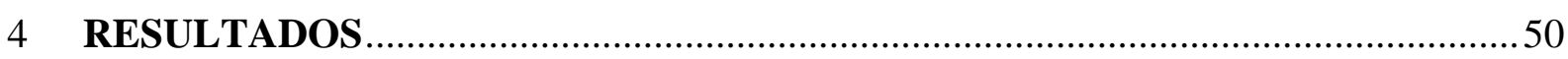

4.1 EFEITO DO FLUORENO, NAFTALENO, NONILFENOL E PROCIMIDONA

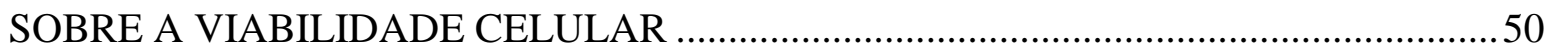

4.2 INVESTIGAÇÃO DO EFEITO DO FLUORENO, DO NAFTALENO, DO NONILFENOL E DA PROCIMIDONA SOBRE A ATIVIDADE TRANSCRICIONAL

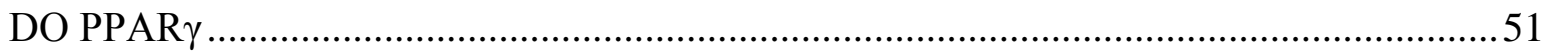

4.3 INVESTIGAÇÃO DA ATIVIDADE DO FLUORENO, NAFTALENO, NONILFENOL E PROCIMIDONA SOBRE A ATIVIDADE TRANSCRICIONAL DO GR $\alpha$

4.4 EFEITOS DO FLUORENO, NAFTALENO, NONILFENOL E PROCIMIDONA SOBRE A ADIPOGÊNESE EM CULTURA DE CÉLULAS

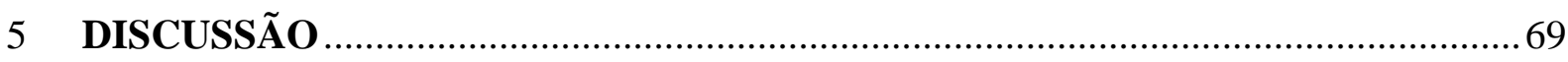

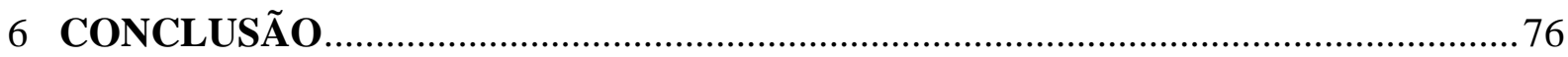


REFERÊNCIAS 


\section{INTRODUÇÃO E REVISÃO DA LITERATURA}

\subsection{OBESIDADE}

Segundo a Organização Mundial da Saúde (World Health Organization - OMS), a obesidade é definida como o acúmulo anormal ou excessivo de gordura, que apresenta risco para a saúde. A medida bruta da obesidade na população, contudo, é dada pelo índice de massa corporal (IMC), obtido por meio da divisão do peso (em quilogramas) pelo quadrado da altura (em metros). Valores de IMC entre 25 e $29,9 \mathrm{~kg} / \mathrm{m}^{2}$ indicam sobrepeso e, acima de $30 \mathrm{~kg} / \mathrm{m}^{2}$, obesidade (WHO, 2015).

A obesidade é uma doença complexa, com dimensões físicas, sociais e psicológicas graves, que afeta praticamente todas as idades e grupos socioeconômicos, e ameaça sobrecarregar ambos os países desenvolvidos e em desenvolvimento. A epidemia da obesidade não é restrita à sociedade industrializada; nos países em desenvolvimento, estimase que mais de 115 milhões de pessoas sofrem de problemas relacionados com a obesidade. Em 1995, havia uma estimativa de 200 milhões de adultos obesos no mundo inteiro e 18 milhões de crianças com menos de cinco anos com sobrepeso. A partir de 2000, o número de adultos obesos aumentou para mais de 300 milhões (WHO, 2015).

Estimativas globais da OMS (2015) indicaram que, em 2014, mais de 1,9 bilhões de adultos, com 18 anos ou mais, estavam acima do peso. Destes, mais de 600 milhões eram obesos. No geral, cerca de $13 \%$ da população mundial adulta, sendo $11 \%$ dos homens e $15 \%$ das mulheres, eram obesos em 2014. Entre adultos com 18 anos ou mais, 38\% de homens e $40 \%$ de mulheres, estavam acima do peso. A projeção é de que, em 2025, cerca de 2,3 bilhões de adultos estejam com sobrepeso e mais de 700 milhões, obesos. O número de crianças com sobrepeso e obesidade no mundo poderia chegar a 75 milhões, caso não haja mudanças (WHO, 2015).

Segundo o Sistema de Vigilância de Fatores de Risco e Proteção para Doenças Crônicas por Inquérito Telefônico do Ministério da Saúde (Vigitel, 2014), o número de brasileiros acima do peso é cada vez maior. O excesso de peso atinge 52,5\% da população adulta do País. Em 2005, essa taxa era de 43\%, o que representa um crescimento de $23 \%$ no período de nove anos. O índice de excesso de peso na população masculina é de 56,5\% contra 49,1\% entre as mulheres. A proporção de pessoas com mais de 18 anos com obesidade no Brasil é de 17,9\% (MINISTÉRIO DA SAÚDE, 2015). 
A prevalência da obesidade e suas complicações estão aumentando e ocorrendo em idades mais jovens. Embora ainda seja pouco esclarecido, o aumento de síndromes relacionadas ao excesso de peso pode estar relacionado com as recentes mudanças na alimentação, no estilo de vida e no meio ambiente (KAROUTSOU; POLYMERIS, 2012). O excesso de peso e a obesidade estão ligados a mais mortes no mundo do que o baixo peso. A obesidade constitui um risco importante para doenças graves, incluindo diabetes mellitus, doença cardiovascular, hipertensão arterial e acidente vascular cerebral, além de certas formas de câncer. As suas consequências para a saúde vão desde o aumento do risco de morte prematura até condições crônicas graves, que reduzem a qualidade de vida global (WHO, 2015). No Brasil, isso corresponde a 72\% dos óbitos (MINISTÉRIO DA SAÚDE, 2015).

A obesidade se desenvolve quando a ingestão de energia excede o gasto energético, gerando balanço energético positivo e o armazenamento do excesso de energia na forma de gordura corporal. Este desbalanço entre ingestão e gasto de energia ocorre devido ao aumento da disponibilidade de alimentos altamente energéticos, às mudanças do ambiente e da prática de atividade física, que podem criar um ambiente "obesogênico". Embora o consumo energético deva exceder o gasto de energia para resultar em ganho de peso, e ambientes "obesogênico" sejam permissivos para que isso ocorra, eles nem sempre são necessários ou suficientes para causar obesidade. O indivíduo pode se tornar obeso na ausência de um ambiente "obesogênico", assim como não necessariamente se torna obeso em um ambiente "obesogênico", sugerindo que outros fatores podem desencadear a obesidade (DHURANDHAR; KEITH, 2014).

Fisiologicamente, a obesidade resulta do aumento do tamanho e do número das células do tecido adiposo, os adipócitos (QUEIROZ et al., 2009). O tecido adiposo é constituído por adipócitos, matriz do tecido conjuntivo, inervações, células do estroma vascular e células do sistema imune, funcionando como uma unidade integrada, tornando o tecido adiposo um verdadeiro órgão endócrino metabolicamente ativo (FRAYN et al., 2003; KERSHAW; FLIER, 2004).

$\mathrm{O}$ aumento do conhecimento a respeito da biologia do tecido adiposo fez com que ele deixasse de ser visto como um reservatório passivo para armazenamento de energia. Em 1987, o tecido adiposo foi identificado como principal local onde ocorre o metabolismo dos esteroides sexuais (SIITERI, 1987) e onde ocorre a produção de adipsina, fator endócrino relacionado à obesidade (FLIER et al., 1987). Em 1994, a leptina foi identificada e caracterizada, estabelecendo o tecido adiposo como um órgão endócrino (ZHANG et al., 1995). Estes e outros conhecimentos fizeram do tecido adiposo um sítio reconhecido por 
expressar e secretar uma variedade de peptídeos bioativos, como as adipocinas, com ações locais (autócrinas/parácrinas) e sistêmicas (endócrinas) (KERSHAW; FLIER, 2004).

O tecido adiposo também expressa inúmeros receptores que permitem responder aos sinais aferentes do sistema endócrino tradicional e do sistema nervoso central (SNC). Além das funções biológicas necessárias para armazenar e liberar energia, o tecido adiposo possui uma maquinaria metabólica que permite uma comunicação com órgãos distantes, incluindo o SNC. Assim, o tecido adiposo é integralmente envolvido na coordenação de uma variedade de processos biológicos, incluindo metabolismo de energia, função neuroendócrina e função imunológica (KERSHAW; FLIER, 2004).

Na obesidade, ocorre a hipertrofia dos adipócitos e também o acúmulo de macrófagos nos depósitos de tecido adiposo (WEISBERG et al., 2003; TORDJMAN et al., 2012). Este processo é observado predominantemente nos depósitos de tecido adiposo visceral, diferentemente dos depósitos de tecido adiposo subcutâneo, onde este fenômeno não é observado (TORDJMAN et al., 2012). Estudos in vitro e ex vivo têm demonstrado que as substâncias secretadas pelos macrófagos influenciam negativamente o adipócito, promovendo proliferação, inflamação e um estado pró-fibrótico dos pré-adipócitos, bem como um estado de resistência à insulina nos adipócitos maduros (DALMAS; CLEMENT.; GUERRE-MILLO., 2011). Os linfócitos, as células citotóxicas naturais (natural killer) e os mastócitos são encontrados no parênquima do tecido adiposo e nos depósitos de fibrose que se acumulam em indivíduos obesos (DIVOUX et al., 2010).

Uma vez que a ativação dos macrófagos e a infiltração no tecido adiposo é iniciada, acredita-se que a resposta inflamatória mediada pelos macrófagos possa prejudicar a ação da insulina nos adipócitos. Os macrófagos, após a ativação, secretam várias citocinas e quimiocinas, tais como TNF- $\alpha$, IL-1, IL-6 e MCP-1, que são conhecidas por causar resistência à insulina em adipócitos (GRIMBLE, 2002; XU et al., 2003). Estas citocinas ativam mais macrófagos, aumentando a produção e a secreção de mais citocinas. Consequentemente, a sinalização da insulina nos adipócitos torna-se cada vez mais prejudicada, levando à lipólise massiva, à necrose e à resistência insulínica sistêmica (XU et al., 2003; KERSHAW; FLIER, 2004).

A função endócrina do tecido adiposo é reforçada pelas consequências metabólicas adversas de sua disfunção, seja por excesso de tecido adiposo ou deficiência deste (KERSHAW; FLIER, 2004). O excesso do tecido adiposo, em particular no compartimento visceral, está associado com a resistência à insulina, hiperglicemia, dislipidemia, hipertensão e estados pró-trombótico e pró-inflamatórios (GRUNDY et al., 2004). 
A ocorrência da obesidade está associada a outras doenças, que compartilham como mecanismo fisiopatológico a resistência à insulina e que compõe a síndrome metabólica, cuja prevalência atinge proporções epidêmicas (GRUNDY et al., 2004; KERSHAW; FLIER, 2004). Embora a interação entre fatores genéticos, alimentação e outros fatores comportamentais sejam considerados importantes fatores causais, ainda é difícil compreender como eles poderiam produzir muitas dessas disfunções metabólicas. Recentemente, o papel do ambiente tem sido foco de grande atenção, na medida em que se observa que a concentração de determinadas substâncias sintéticas no ambiente coincidiu com o aumento da incidência da obesidade. Estas substâncias têm sido implicadas no comprometimento de muitos dos mecanismos envolvidos no controle do peso (BAILLIE-HAMILTON, 2002).

\subsection{DESREGULADORES ENDÓCRINOS}

Ao longo das últimas décadas, foi relatado que certos contaminantes ambientais liberados por atividades antrópicas representam uma "nova" ameaça epigenética à saúde do ecossistema. Estes produtos químicos podem imitar hormônios naturais, desencadear ação oposta a dos hormônios endógenos ou mesmo alterar a síntese e a excreção de hormônios. Em razão destes efeitos, eles foram chamados de desreguladores endócrinos (DE) (KAROUTSOU; POLYMERIS, 2012). O Programa Internacional em Segurança Química (International Programme on Chemical Safety, IPCS) define os DE como uma substância exógena ou uma mistura de substâncias que altera a função do sistema endócrino e, consequentemente, gera efeitos adversos para a saúde de um organismo intacto, de seus descendentes ou (sub) populações (WHO, 2015).

O sistema endócrino é complexo, envolvendo vários órgãos que contribuem para uma resposta regulatória multifacetada. Tal complexidade dificulta a compreensão dos mecanismos específicos por meio dos quais os DE exercem sua atividade sobre este sistema (KAROUTSOU; POLYMERIS, 2012). Recentemente, várias interações entre o tecido adiposo e os DE foram descritas, sugerindo que o tecido adiposo tenha um papel significativo na cinética e na toxicidade desses compostos (KIM et al., 2011). Estas substâncias são armazenadas no tecido adiposo e podem ser passadas para os descendentes na fase de desenvolvimento, através da placenta ou do ovo (ELOBEID; ALLISON, 2008).

Os DE podem ser encontrados no ambiente por ocorrência natural, como os fitoestrógenos, compostos com atividade estrogênica mais fraca que a dos estrogênios 
endógenos, e estar presentes nos grãos, em alguns fungos, nas gramíneas, nas ervas, nos legumes e nas frutas. Podem, também, ser encontrados no ambiente por fontes antropogênicas, como é o caso dos compostos orgânicos sintéticos, sintetizados a partir do carbono, do hidrogênio, do nitrogênio e do cloro (ELOBEID; ALLISON, 2008). Este é o caso do éter difenil polibromado (PBDE), dietilestilbestrol (DES), bisfenol A (BPA), pesticidas organofosforados (dicloro-difenil-tricloroetano, DDT), dioxinas, bifenilos policlorados (PCBs), alguns organoclorados, retardadores de chama polibromados, perfluorados, ftalatos, hidrocarbonetos aromáticos policíclicos, alquilfenois, metais pesados, solventes e alguns produtos domésticos, como produtos de limpeza, purificadores de ar, tinturas de cabelo, cosméticos e protetores solares (ELOBEID; ALLISON, 2008; DE COSTER; VAN LAREBEKE, 2012). Alguns desses compostos são resistentes à degradação química e biológica, sendo denominados Poluentes Orgânicos Persistentes (POP), a maioria deles também classificada como DE (ELOBEID; ALLISON, 2008; VALENTINO et al., 2013).

Os humanos e os animais são expostos aos DE por várias vias, incluindo a ingestão, inalação, injeção, contato transdérmico e transporte transplacentário (DE COSTER; VAN LAREBEKE, 2012). O contato direto com esses compostos pode ocorrer por meio dos inseticidas, herbicidas, fungicidas e fumigantes. O contato indireto, por sua vez, pode ocorrer por meio da ingestão de água ou de alimentos contaminados. Os DE entram no ambiente através de várias fontes (ELOBEID; ALLISON, 2008), e também podem ser encontrados nos resíduos industriais (DE COSTER; VAN LAREBEKE, 2012; REGNIER; SARGIS, 2014). Na Figura 1, são apresentados esquematicamente as fontes, vias de exposição e alvos dos DE. 


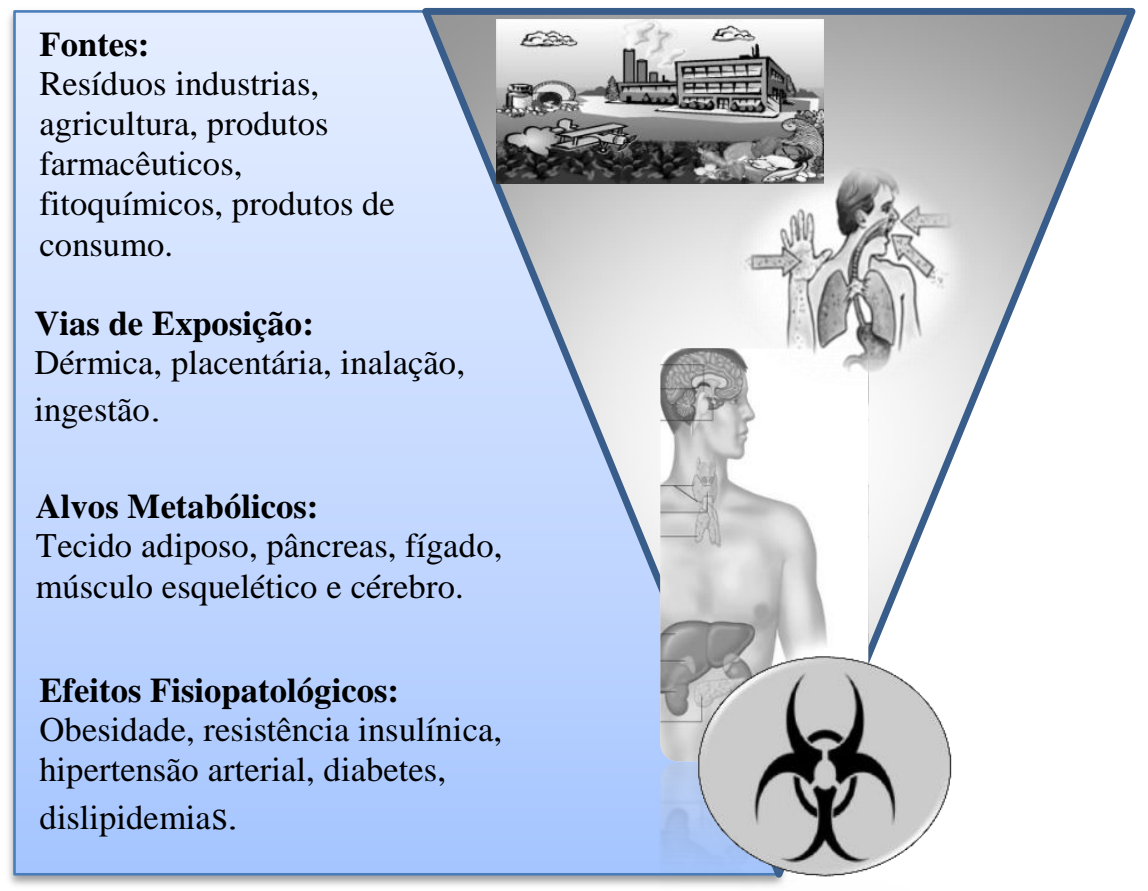

Figura 1 - Fontes e vias de exposição, alvos metabólicos e consequências fisiopatológicas dos DE. Adaptada de: Neel; Sargis (2011).

Em geral, as atividades hormonais dos DE podem ocorrer por vários mecanismos, diretos e indiretos. Os DE podem atuar em vias que levam à alteração da formação de sinapses neuronais (SHINOMIYA; SHINOMIYA, 2003), afetando a liberação de substâncias produzidas pelo cérebro que, por sua vez, se ligam aos receptores nucleares (ELOBEID; ALLISON, 2008). Podem também atuar em vias enzimáticas envolvidas na biossíntese e metabolismo de esteroides, e em vários outros mecanismos que convergem sobre o sistema endócrino (DIAMANTI-KANDARAKIS et al., 2009). O mecanismo aparentemente mais comum é a atuação dos DE sobre os receptores nucleares, por meio de ação agonista ou antagonista (ELOBEID; ALLISON, 2008; DIAMANTI-KANDARAKIS et al., 2009).

Muitos DE são caracterizados como ligantes de receptores nucleares envolvidos na biologia do tecido adiposo, mais especificamente na diferenciação do adipócito a partir de precursores e na função dos adipócitos maduros (Figura 2). Entre estes receptores, destacamse os receptores ativados por proliferadores peroxissomais (PPAR), receptor de hormônio tireoidiano (TR), receptores $X$ do fígado (LXR), receptor farsenoide $X(F X R)$, receptores alfa relacionado ao estrogênio $(\mathrm{ERR} \alpha)$, receptores retinoide $\mathrm{X}(\mathrm{RXR})$ e receptores de glicocorticoides (GR). Tais receptores são considerados alvos potenciais para regulação da adipogênese e, potencialmente, de vias metabólicas envolvidas no desenvolvimento da 
obesidade (SARGIS et al., 2010). É possível que a modulação da atividade destes receptores nucleares pelos DE explique, pelo menos em parte, seu efeito obesogênico.

Segundo a "hipótese dos obesogênicos ambientais", os contaminantes ambientais com atividade desreguladora endócrina contribuiriam para o desenvolvimento da obesidade e dos distúrbios metabólicos a ela associados. Em particular, ao fenótipo inflamatório do tecido adiposo nesta condição, com aumento da secreção de citocinas pro-inflamatórias e diminuição das citocinas anti-inflamatórias, e resultante diminuição da sensibilidade à insulina (GREGOR; HOTAMISLIGIL; 2011; VALENTINO et al. 2013).

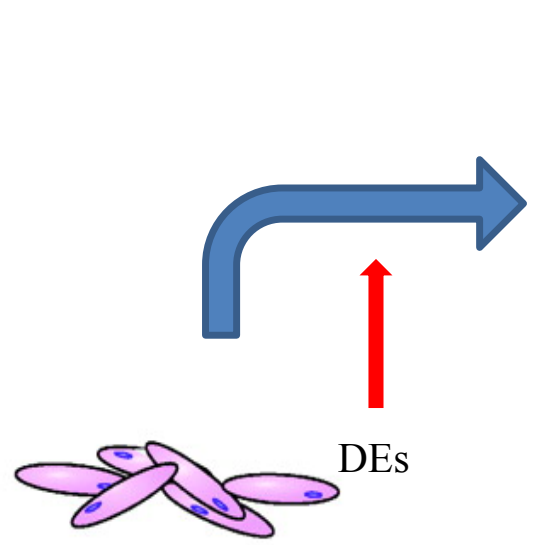

Pré-adipócitos

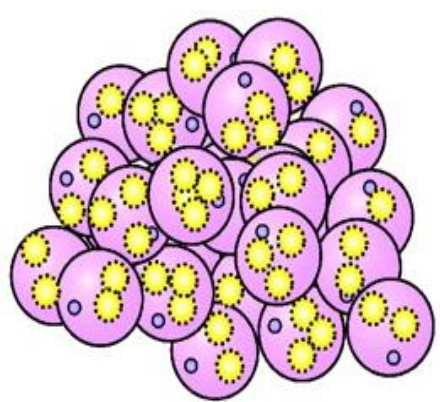

Adipócitos Maduros disfuncionais

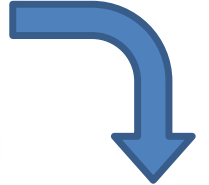

\section{Acúmulo de gordura}

Síndrome metabólica

Figura 2 - Indução da diferenciação de pré-adipócitos em adipócitos maduros pelos desreguladores endócrinos. Os desreguladores endócrinos têm a capacidade de induzir o acúmulo de lipídeos no interior dos adipócitos e influenciar a função do adipócito maduro, com impacto potencial sobre o desenvolvimento de complicações metabólicas relacionadas à obesidade.

Adaptado de: Mogi; Iwai; Horiuchi (2006).

Há vários estudos que evidenciam a associação entre a exposição a DE e a ocorrência de doenças humanas, como neoplasias malignas (câncer de mama, de próstata e de testículo), o diabetes, a obesidade e a diminuição da fertilidade (DE COSTER e VAN LAREBEKE, 2012). Um dos primeiros compostos sintéticos a ter sua atividade desreguladora endócrina caracterizada foi o dietilestilbestrol (DES), o primeiro estrogênio artificial. No estudo realizado por Laitman (2002), foi observada redução da fertilidade de mulheres expostas ao DES durante vida intrauterina. Além disso, os filhos de mulheres expostas ao DES durante a gestação apresentaram aumento da prevalência de anomalias urogenitais, e as mulheres expostas ao DES na vida adulta (mães) apresentaram um risco aumentado de desenvolvimento de câncer de mama. 
Outro composto químico considerado modelo de DE, o bisfenol A (BPA), é um componente do plástico, que induz alterações nos padrões de diferenciação e de proliferação celular, e no tamanho da próstata. Tais alterações, por sua vez, estão associadas a um aumento do risco do câncer de próstata (MAFFINI et al., 2006). Estudos realizados ex vivo, com préadipócitos 3T3-L1 obtidos de camundongos Swiss, e in vivo sugeriram a relação entre o BPA e a obesidade. Ele é capaz de induzir a diferenciação dos pré-adipócitos 3T3-L1 em adipócitos maduros e de acelerar a diferenciação induzida pela insulina. (MASUNO et al., 2002). Estudos in vivo, realizados com filhotes de ratas Sprague-Dawley expostas ao BPA, apresentaram aumento do peso corporal após o nascimento, que continuou até a idade adulta (RUBIN et al., 2001; ELOBEID; ALLISON, 2008). Esta mesma correlação entre a exposição ao BPA e excesso de peso foi observada em humanos. Recentemente, Li et al. (2013) observaram a correlação entre a concentração urinária de BPA e o excesso de peso em crianças em idade escolar, em Shanghai, na China. Os autores observaram, entre as meninas, uma relação dose-resposta entre o aumento da concentração urinária de BPA e o aumento do risco do excesso de peso, sugerindo o potencial obesogênico do BPA.

Os ftalatos, utilizados sobretudo em plásticos PVC, também já foram relacionados a alterações endócrinas. Em estudos realizados com roedores, foram observados efeitos adversos relacionados à exposição aos ftalados, de curto e longo prazo. Entre estes efeitos, destacam-se alterações da concentração de insulina sérica, da glicemia, do conteúdo hepático de glicogênio, de T3 (triiodotironina), de T4 (tiroxina), de TSH (hormônio estimulante da tireoide) e do cortisol circulantes (HEUDORF; MERSCH-SUNDERMAN; ANGERER, 2007). Em outro estudo, realizado a partir de dados do National Health and Nutrition Examination Survey (NHANES) de americanos adultos, mostrou-se correlação entre as concentrações urinárias dos metabólitos do ftalato e obesidade abdominal e resistência à insulina (STAHLHUT et al., 2007).

Outro DE conhecido é o tributilestanho (TBT), um agente antifúngico, que se mostrou capaz de desregular a adipogênese em cultura de células (GRUN; BLUMBERG, 2006; TABB; BLUMBERG, 2006). Foi observado que o TBT induz a diferenciação dos préadipócitos 3T3-L1 em adipócitos maduros, e também ativa dois receptores nucleares importantes na adipogênese, o PPAR $\gamma$ e o RXR; estes efeitos foram observados em concentrações de $10 \mathrm{nM}$ e $100 \mathrm{nM}$ do TBT, que são ambientalmente relevantes, e podem implicar seu potencial adipogênico em mamíferos (KERSTEN, 2002; GRUN et al., 2006; TABB; BLUMBERG, 2006; ELOBEID; ALLISON, 2008). Em experimentos realizados in vivo, foi observado que a exposição prolongada ao TBT durante a vida fetal pode resultar em 
aumento da gordura corporal e estar envolvida no desenvolvimento da obesidade após o nascimento (GRUN et al., 2006; ELOBEID; ALLISON, 2008).

Uma característica peculiar e comum aos desreguladores endócrinos é a ausência de relação linear entre a dose/concentração de exposição e a ocorrência ou intensidade de seus

efeitos. É observado que qualquer nível de exposição, desde infinitamente baixo a alto, pode causar anomalias endócrinas ou reprodutivas, principalmente se ocorrer durante uma janela de exposição crítica do desenvolvimento (SHEEHAN et al., 1999). Além disso, doses baixas podem exercer efeitos mais acentuados do que doses mais elevadas, e os DE podem apresentar curvas dose-respostas não tradicionais, tais como em U invertido ou curvas em forma de U ( DIAMANTI-KANDARAKIS et al., 2009; BELCHER et al., 2014).

Neste estudo, foi investigado o potencial adipogênico, em cultura de células, de 4 DE, o fluoreno, o naftaleno, o nonilfenol e a procimidona.

\subsubsection{FLUORENO E NAFTALENO}

Os hidrocarbonetos aromáticos policíclicos (polycyclic aromatic hydrocarbon, $\mathrm{PAH}$ ) são uma família de compostos tóxicos ambientais, persistentes e lipofílicos, que se originam a partir da combustão incompleta de materiais orgânicos (IARC, 2010). Essa combustão incompleta dos materiais orgânicos pode ocorrer em altas temperaturas $\left(500-800^{\circ} \mathrm{C}\right)$ ou em temperaturas um pouco mais baixas $\left(100-300^{\circ} \mathrm{C}\right)$, durante longos períodos, resultando na produção dos PAH (HARITASH; KAUSHIK, 2009).

Os PAH possuem dois ou mais anéis aromáticos fundidos. Os PAH de baixo peso molecular, com dois ou três anéis aromáticos, são emitidos na fase gasosa, e os PAH de alto peso molecular, com cinco ou mais anéis, são emitidos na fase sólida, na forma de partículas (SCINICARIELLO; BUSER, 2014). À medida que aumenta o peso molecular do PAH, sua solubilidade em água diminui, os pontos de fusão e de ebulição aumentam, e a pressão de vapor diminui (HARITASH; KAUSHIK, 2009). As estruturas dos dois PAH investigados neste estudo, o fluoreno e o naftaleno, estão apresentadas na Figura 3. 


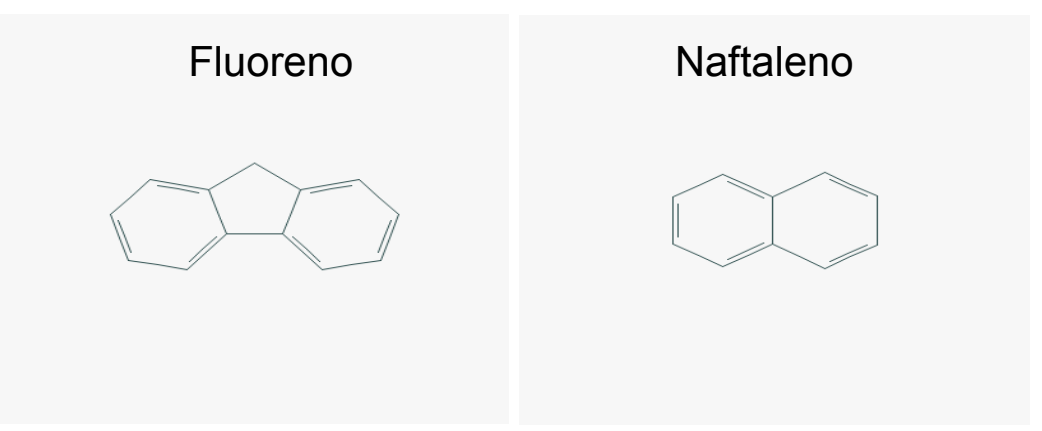

Figura 3 - Estrutura química do fluoreno e do naftaleno. Fonte: PubChem (2015)

Eles não se degradam facilmente em condições naturais e, assim, apresentam potencial de bioacumulação. Estão presentes em todos os componentes do meio ambiente. Embora sejam os principais poluentes do ar, o solo atua como fonte depositária final desses produtos químicos. Depois de depositados no ambiente, o destino pode ser a volatilização, a fotooxidação, a oxidação química, a adsorção em partículas do solo, a lixiviação e a degradação microbiana (HARITASH; KAUSHIK, 2009). Por estarem presentes no ambiente, a intensidade de exposição aos PAH pode ser mensurável em atmosferas urbanas, na superfície da água, nos sedimentos, no solo, nas plantas e até mesmo na população e em diferentes organismos, como os peixes (WANG et al., 2013).

As fontes de exposição aos PAH são várias, entre elas o carvão, a queima de combustíveis, o fogão à lenha, as carnes grelhadas e carbonizadas, a farinha contaminada, os produtos de panificação, os alimentos processados e em conserva, a fumaça do cigarro (WANG et al., 2013), o ar poluído pelo tráfego pesado de veículos, as fontes industriais e o contato com o ar, a água ou o solo perto de depósitos que possuem resíduos perigosos. Assim, eles estão amplamente presentes em nosso ambiente (HUANG et al., 2006; SCINICARIELLO; BUSER, 2014).

O tabaco é a principal fonte de exposição humana aos PAH. Goldman et al. (2001) mediram a concentração dos PAH em amostras de tecido pulmonar de indivíduos fumantes e não fumantes. A soma das concentrações de PAH foram maiores em fumantes, havendo uma correlação positiva entre o tabagismo e a concentração deste DE.

Os PAH são identificados como tóxicos, com potencial mutagênico, carcinogênico e desregulador do sistema endócrino (BOSTROM et al., 2002; PEIFFER et al., 2013). Eles aparecem em misturas complexas e estão entre as primeiras substâncias associadas com o desenvolvimento de tumores em seres humanos e em outros mamíferos expostos experimentalmente. Alguns compostos pertencentes à classe dos $\mathrm{PAH}$, como o 7,12- 
dimetilbenz[a]antraceno (DMBA) e 3-metilcolantreno (3MC) foram utilizados como compostos modelo para o estudo dos mecanismos moleculares de câncer de mama em ratas Sprague-Dawle. Os tumores mamários induzidos por PAH são predominantemente estrogênio-dependentes (SANTODONATO, 1997).

$\mathrm{O}$ principal produto metabólico dos $\mathrm{PAH}$ são os $\mathrm{PAH}$-hidroxilados, que são estruturalmente semelhantes ao estrogênio (WENGER et al., 2009). Este aspecto é consistente com dados de estudos que mostraram a capacidade dos PAH em atuar desregulando vias mediadas pelo estrogênio, por meio de ação anti-estrogênica ou estrogênica (OHURA et al., 2010; SIEVERS et al., 2013). Alguns PAH-hidroxilados, ainda, apresentam efeitos antiandrogênicos (VINGGAARD; HNIDA; LARSEN, 2000) e atuam como antagonistas do TR (SUN et al., 2008).

Alguns estudos relacionaram os PAH também com a obesidade. Estudo in vivo com camundongos em idade adulta expostos a diferentes concentrações de PAH mostraram aumento do acúmulo lipídico no tecido adiposo, além de aumento da expressão do PPAR $\gamma$ e de alguns genes envolvidos na síntese de ácidos graxos (JIN et al., 2014). Em outro estudo também envolvendo camundongos expostos ao PAH, Irigaray et al. (2006) observaram o comprometimento da lipólise no tecido adiposo e o aumento do ganho de peso e da massa gorda nesses animais. Em um estudo transgeracional, com filhotes de camundongos fêmeas expostas na gravidez a diferentes concentrações de PAH, foi observado, no tecido adiposo, aumento da expressão do RNAm dos genes que codificam o PPAR $\gamma$, a proteína alfa de ligação ao acentuador CCAAT (C/EBP $\alpha)$, a cicloxigenase tipo 2 (Cox2), a sintase de ácido graxo (FAS) e a adiponectina. Todos são genes envolvidos na diferenciação de adipócitos, na sensibilidade à insulina e na lipogênese (YAN et al., 2014).

No NHANES, foram coletadas amostras de urina da população dos Estados Unidos entre os anos de 2001 e 2002 e aproximadamente 100\% das amostras de urina coletadas apresentaram metabólitos de naftaleno e de fluoreno (LI et al., 2008). Este dado indica que esses dois compostos estão em contato direto com a população, por meio da ingestão, da inalação e da absorção cutânea. A principal via de exposição ao naftaleno é a inalatória, e a exposição ocorre a partir da poluição ambiental. As principais vias de exposição ao fluoreno são a ingestão (alimentos contaminados) e a inalatória (LI et al., 2008).

O fluoreno é um dos PAH abundantes no ar e pode contribuir para alterações neurocomportamentais. Em estudos envolvendo ratos Wistar machos adultos expostos ao fluoreno, foram observados distúrbios comportamentais relacionados à ansiedade (PEIFFER et al., 2013). 
O naftaleno é um micropoluente comum na água potável, no solo, no ar e nos alimentos (SAMANTA; SINGH; JAIN, 2002), e é um constituinte do diesel e do cigarro. O naftaleno presente na atmosfera é sujeito a reações de degradação induzidas fotoquimicamente, fazendo com que partículas degradadas do naftaleno fiquem acumuladas no ambiente. Ele pode ser encontrado em grande concentração no ar, elevando o grau de exposição da população por meio da inalação, uma vez que a liberação desta substância se dá a partir da combustão de combustíveis e pela fumaça de cigarro (PREUSS; ANGERER; DREXLER, 2003).

É considerado um composto químico tóxico e com potencial carcinogênico (PREUSS; ANGERER; DREXLER, 2003). Liga-se covalentemente a moléculas no fígado, rins e tecido pulmonar, aumentando assim a sua toxicidade. Ele é também um inibidor da respiração mitocondrial. O envenenamento agudo pelo naftaleno em humanos pode conduzir a anemia hemolítica e a nefrotoxicidade. Além disso, foram observadas alterações oftalmológicas em trabalhadores expostos por via cutânea ao naftaleno (SAMANTA; SINGH; JAIN, 2002).

Recentemente, Scinicariello e Buser (2014) analisaram amostras de urina coletadas de crianças com idade entre 6 e 11 anos, entre os anos de 2001 e 2006, como uma forma de avaliar a exposição pré-natal a essa classe de DE, uma vez que consideraram que a presença de PAH na urina, nesta faixa etária, representaria resultado de exposição durante a vida fetal. A partir dos dados cedidos pelo NHANES a respeito destas crianças, eles associaram a concentração urinária dos metabólitos de $\mathrm{PAH}$, dentre eles metabólitos do fluoreno e do naftaleno, com o IMC e a medida da circunferência abdominal. Os autores observaram uma associação positiva entre os PAH e a obesidade nessas crianças, sugerindo a exposição precoce a estes compostos e sua possível relação com o desenvolvimento de excesso de peso.

\subsubsection{NONILFENOL}

Os etoxilatos de alquifenois (alkylphenol ethoxylates - APE) são uma classe de tensoativos não iônicos amplamente usados na fabricação de detergentes, plásticos, tintas, cosméticos e pesticidas. O nonilfenol é um produto da degradação microbiana do e nonilfenol entoxilato (NPE), o membro mais predominante dos tensoativos APE (HAO et al., 2012). Depois do seu uso, o NPE pode ser descartado em ambiente aquático, onde a cadeia de polietoxilato é quebrada durante o tratamento anaeróbico de águas residuais e, assim, o NPE é transformado em nonilfenol. O nonilfenol pode ser encontrado nas águas dos rios, na água 
para consumo, nos peixes, nos alimentos envolvidos por plásticos e em materiais de poliestireno (MASUNO et al., 2003). Possui baixa solubilidade em água e foi identificado como o metabólito mais crítico dos APE devido à sua resistência à biodegradação, sua capacidade de bioacumulação e a sua toxicidade.

Na estrutura química do nonilfenol há um anel de fenol, que é semelhante ao do $17 \beta$ estradiol. Os efeitos estrogênicos do nonilfenol foram documentadas em uma série de estudos in vivo e in vitro (YANG et al., 2015). Estudos in vivo e in vitro mostraram que o tratamento com nonilfenol suprimiu a secreção de testosterona pelas células de Leydig (GONG ; HAN, 2006; WU et al., 2010) e prejudicou a espermatogênese. Outro estudo com células de Sertoli (linhagem TM4) mostrou que o nonilfenol pode influenciar a expressão de alguns genes nessas células, como o que codifica o receptor de estrogênio beta (ER- $\beta$ ), o receptor de progesterona (PR), o receptor de androgênio (AR) e o receptor hormônio folículo estimulante (FSHR) (LIU et al., 2014).

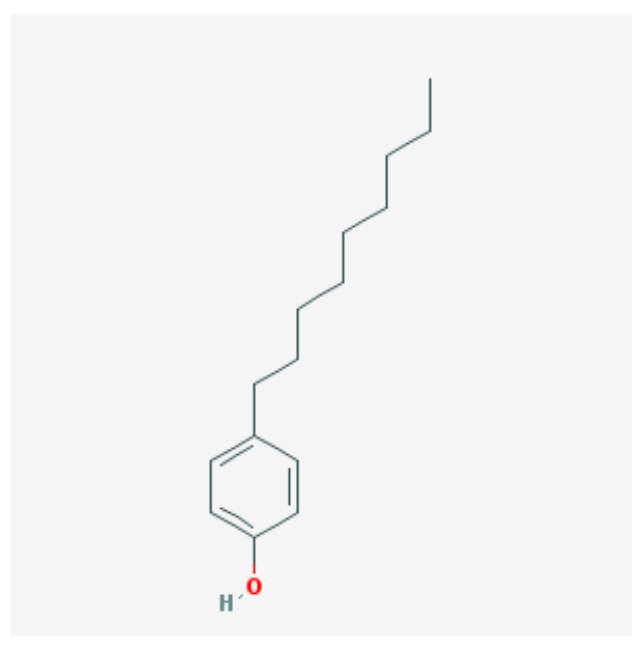

Figura 4 - Estrutura do nonilfenol. Fonte: PubChem (2015).

Masuno et al. (2002) observaram o efeito de nonilfenol sobre a proliferação celular e a formação de adipócitos em culturas de células 3T3-L1 totalmente diferenciadas. Os seus resultados indicaram que nonilfenol foi capaz de estimular a proliferação de células 3T3-L1, porém inibiu a diferenciação de adipócitos. Contrariando os resultados encontrados por Masuno e colaboradores, Hao et al. (2012) observaram que o nonilfenol foi capaz de induzir a diferenciação de adipócitos murinos 3T3-L1 de forma dose-dependente. Estes mesmos autores mostraram, in vivo, que a exposição aguda ao nonilfenol aumentou a expressão de marcadores de lipogênese e adipogênese no tecido adiposo. Eles ainda sugeriram que a exposição perinatal ao nonilfenol pode aumentar a incidência de obesidade no período pós- 
natal. Outro estudo com animais comprovou os achados transgeracionais de Hao et al., na medida em que mostrou que a exposição ao nonilfenol no período fetal ou pós-natal precoce, pode induzir o aparecimento de alterações no tecido adiposo e levar à obesidade. Além disso, esse efeito pode ser percebido por várias gerações (Zhang et al., 2014).

Como mencionado anteriormente, o nonilfenol é amplamente presente no ambiente. Em 2009, um estudo envolvendo mulheres do sul da Espanha investigou a presença de resíduos de nonilfenol em 20 amostras de tecido adiposo, e a encontrou em 100\% delas (LOPEZ-ESPINOSA et al., 2009).

\subsubsection{PROCIMIDONA}

Os fungicidas dicarboximidas têm sido utilizados na agricultura há cerca de 20 anos como uma das principais formas de controle de patógenos nas culturas, particularmente da Botrytis cinérea, principal agente causador do mofo cinzento nas uvas (HOSOKAWA et al., 1993).

A procimidona (Figura 5) é um fungicida dicarboximida estruturalmente relacionado com o fungicida bem caracterizado vinclozolina (OSTBY et al., 1999). É um composto químico utilizado para matar e inibir o crescimento de fungos nas plantações agrícolas, na madeira, nos plásticos, nas piscinas e em outros materiais. Ele é usado para controlar as pragas fúngicas no cultivo de hortaliças, plantas ornamentais, tubérculos, frutas, girassóis e também no tratamento de sementes pós-colheita (RADICE et al., 2004)

Figura 5 - Estrutura química da procimidona, pertencente à família de fungicidas dicarboximidas. 
Fonte: PubChem.(2015).

A procimidona, assim a vinclozolina, outro membro da família dos fungicidas dicarboximida, apresenta atividade anti-androgênica in vivo. Os metabólitos da vinclozolina, M1 e M2, se ligam aos receptores de andrógenos (AR) dos mamíferos e agem como antagonistas, inibindo a expressão de genes andrógeno-dependentes in vivo e in vitro por meio da inibição da ligação do AR ao DNA (KELCE et al., 1994; GRAY; KELCE, 1996). A procimidona também apresentou atividade anti-androgênica in vitro e in vivo. In vitro, a procimidona agiu como antagonista de AR inibindo ativação da transcrição induzida pela diidrotestosterona (DHT), o metabólito ativo da testosterona, importante no desenvolvimento do seio urogenital e da genitália externa (OSTBY, 1999). In vivo, a exposição à procimidona foi associada à malformação dos órgãos sexuais, como atrofia e fibrose da próstata, hipospadias e também presença de mamilos nos machos e redução da distância anogenital. Além disso, a exposição perinatal à procimidona reduziu a virilização e induziu a feminização de ratos machos (GRAY; KELCE, 1996; WOLF et al., 1999).

A procimidona apresenta estrutura molecular semelhante à da flutamida, um antiandrogênico não esteroidal sintético, usado no tratamento de câncer de próstata ou em algumas doenças causadas pelo excesso de andrógenos. (IMPERATO-MCGINLEY et al.,1992; HOSOKAWA et al., 1993; WOLF et al., 1999). Em 2003, um estudo realizado por Nilleman e colaboradores confirmou o efeito anti-androgênico da procimidona e sua capacidade de induzir malformação dos órgãos reprodutivos em animais. Eles mostraram, ainda, a capacidade da procimidona em aumentar as concentrações circulantes de FSH e LH em animais. O FSH é o hormônio folículo estimulante e o LH é o hormônio luteinizante; concentrações circulantes aumentadas desses hormônios sugerem que a procimidona antagoniza os receptores centrais de andrógenos, bloqueando o mecanismo de retroalimentação negativa da testosterona sobre o hipotálamo e a hipófise (NILLEMAN et al., 2002). Além de possuir atividade anti-androgênica, a procimidona apresenta efeito estrogênico (RADICE et al, 2002).

$\mathrm{Na}$ Tabela 1, estão descritas as principais características dos compostos investigados neste estudo. 
Tabela 1 - Fonte de exposição e efeitos desreguladores endócrinos do fluoreno, naftaleno, nonilfenol e procimidona.

\begin{tabular}{|c|c|c|c|c|}
\hline Compostos & Fluoreno & Naftaleno & Nonilfenol & Procimidona \\
\hline Família & $\begin{array}{l}\text { Hidrocarbonetos } \\
\text { aromáticos } \\
\text { policíclicos }\end{array}$ & $\begin{array}{l}\text { Hidrocarbonetos } \\
\text { aromáticos } \\
\text { policíclicos }\end{array}$ & $\begin{array}{l}\text { Etoxilatos de } \\
\text { alquifenois }\end{array}$ & $\begin{array}{l}\text { Fungicida } \\
\text { dicarboximida }\end{array}$ \\
\hline Utilização & $\begin{array}{l}\text { Fabricação de } \\
\text { cigarro e em } \\
\text { combustíveis }\end{array}$ & $\begin{array}{l}\text { Fabricação de } \\
\text { cigarro e em } \\
\text { combustíveis }\end{array}$ & $\begin{array}{l}\text { Fabricação de } \\
\text { detergentes, } \\
\text { plásticos, tintas, } \\
\text { cosméticos e } \\
\text { pesticidas }\end{array}$ & $\begin{array}{l}\text { Plantações } \\
\text { agrícolas, na } \\
\text { madeira, plásticos, } \\
\text { piscinas, cultivo de } \\
\text { hortaliças, plantas } \\
\text { ornamentais, } \\
\text { tubérculos, frutas, } \\
\text { girassóis e no } \\
\text { tratamento de } \\
\text { sementes pós- } \\
\text { colheita }\end{array}$ \\
\hline $\begin{array}{l}\text { Fontes de } \\
\text { exposição de } \\
\text { humanos }\end{array}$ & $\begin{array}{l}\text { Ar, água, solo, } \\
\text { alimentos }\end{array}$ & $\begin{array}{l}\text { Ar, água, solo, } \\
\text { alimentos }\end{array}$ & $\begin{array}{l}\text { Água, alimentos, } \\
\text { contato com a pele }\end{array}$ & $\begin{array}{l}\text { Alimentos, contato } \\
\text { com a pele }\end{array}$ \\
\hline $\begin{array}{l}\text { Principal } \\
\text { atividade }\end{array}$ & Estrogênica & Estrogênica & $\begin{array}{l}\text { Estrogênica, } \\
\text { adipogênica, anti- } \\
\text { androgênica }\end{array}$ & Anti-androgênica \\
\hline
\end{tabular}

\subsection{RECEPTORES NUCLEARES}

Os receptores nucleares são membros de uma superfamília de fatores de transcrição regulados por ligantes; estes últimos têm em comum a característica de serem pequenas moléculas lipofílicas (GRUN; BLUMBERG, 2007). Eles regulam a expressão de gene com papel crítico alvo no desenvolvimento e nas vias de sinalização hormonais homeostáticas (SARGIS et al., 2010), incluindo aquelas envolvidas na reprodução, desenvolvimento e metabolismo energético (ROBINSON-RECHAVI; ESCRIVA GARCIA; LAUDET, 2003). 
Todos os membros dessa superfamília têm característica estrutural semelhante, com organização em domínios funcionais (Figura 5), a saber (i) o domínio amino-terminal (A/B), (ii) o domínio de ligação ao DNA (DBD, domínio C), (iii) a região de dobradiça (hinge, domínio D) e (iv) o domínio de ligação ao ligante (LBD, domínio E) (GUAN et al., 2005).

\begin{tabular}{|l|l|l|l|}
\hline NH2-Terminal & DBD & H & LBD \\
\hline
\end{tabular}

Figura 6 - Estrutura primária dos receptores nucleares. Representação de seus domínios funcionais: (i) NH2terminal: domínio A/B amino-terminal, (ii) DBD: domínio de ligação ao DNA (C), (iii) H: região de dobradiça (D), (iv) LBD: domínio de ligação ao ligante (E).

Adaptado de: Barra et al (2004).

Quando um ligante com atividade agonista se liga ao receptor nuclear, ocorre uma modificação na conformação da estrutura do receptor desencadeando uma cascata de eventos que termina com a ativação da transcrição de genes alvo regulados positivamente pelo receptor ativado. Essa cascata de eventos envolve a dissociação de complexos correpressores e o recrutamento de complexos coativadores, o que então recruta a maquinaria de transcrição basal (Figura 7) (GUAN et al., 2005). Muitos compostos lipofílicos, como os DE, possuem a capacidade de se ligar especificamente a esses receptores nucleares podendo interferir na ligação do ligante endógeno e na via de sinalização do receptor (CASALS-CASAS; FEIGE; DESVERGNE, 2008).

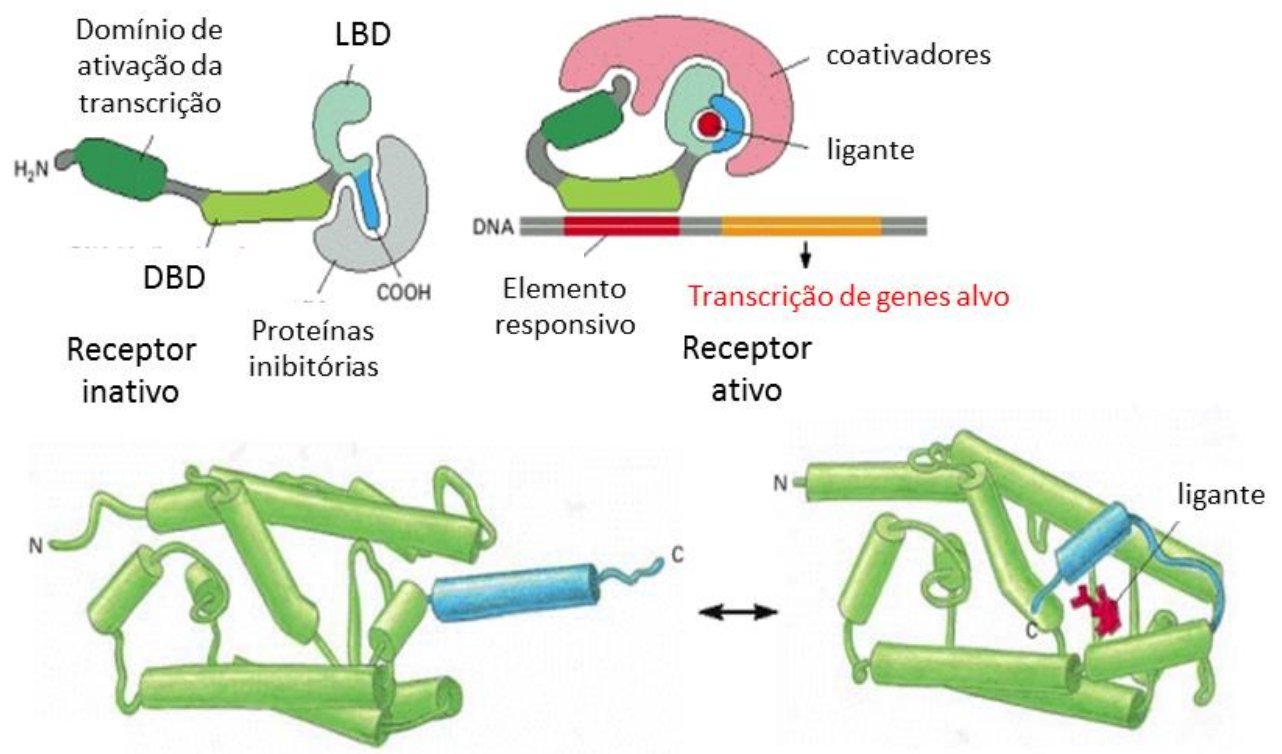

Figura 7 - Receptor nuclear na sua forma inativa (não ligada), interagindo com complexos correpressores, e ativa (ligada), interagindo com coativadores (parte superior). A ligação do ligante com atividade agonista ao LBD modifica a sua conformação, especificamente da hélice 12 (em azul), que adota uma posição mais próxima do restante do LBD.

Adaptado de: ALBERTS et al. (2002). 
Há dois membros desta superfamília de receptores que são cruciais para a diferenciação dos adipócitos, o receptor ativado por proliferadores peroxissomais $\gamma$ (PPAR $\gamma$ ) e o receptor de glicocorticoide (GR) ( GREGOIRE; SMAS; SUL., 1998; SARGIS et al., 2010).

Há três subtipos de PPAR, o PPAR $\alpha,-\gamma$ e o $-\delta / \beta$. Eles estão distribuídos de formas diferentes nos tecidos e apresentam diferentes papéis fisiológicos (ZOETE; GROSDIDIER; MICHIELIN, 2007). Os PPAR são receptores órfãos (MICHALIK et al., 2006) e para regular a transcrição, formam um heterodímero com o RXR $\alpha$ e esse complexo, por sua vez, se liga ao elemento responsivo do PPAR na região reguladora do gene alvo (DIAMANTIKANDARAKIS et al., 2009).

O PPAR $\alpha$ é expresso predominantemente no fígado, nos rins, no coração e no músculo. É importante na absorção e na oxidação dos ácidos graxos, e no metabolismo das lipoproteínas. Entre seus ligantes exógenos, destacam-se os fibratos, utilizados no tratamento da hipertrigliceridemia. O PPAR $\delta$ é expresso na maioria dos tipos celulares, em especial no fígado, no intestino, no rim, no tecido adiposo abdominal, no músculo esquelético e nos tecidos que estão envolvidos no metabolismo lipídico. Não apresenta, até o momento, ligante sintético utilizado na prática clínica (WILLSON et al., 2000; MICHALIK et al., 2006).

O PPAR $\gamma$, por sua vez, é expresso em abundância no tecido adiposo, no intestino grosso e nos macrófagos. Ele é o alvo molecular de uma classe de drogas antidiabéticas sensibilizadores de insulina, as glitazonas, como a rosiglitazona, a pioglitazona e a troglitazona (WILLSON et al., 2000; ZOETE; GROSDIDIER; MICHIELIN, 2007). A troglitazona foi retirada do mercado por se associar a hepatotoxicidade significativa (YKIJÄRVINEN, 2004) e a rosiglitazona, a aumento do risco de infarto do miocárdio (NISSEN; WOLSKI, 2007). A pioglitazona ainda é comercializada, embora tenha sido associada a aumento do risco de câncer de bexiga (COLMERS et al.,2012).

O PPAR $\gamma$ é o principal receptor nuclear responsável pela regulação da adipogênese. Ele é expresso principalmente no tecido adiposo e quando ativado promove a diferenciação dos adipócitos e a indução de enzimas lipogênicas. Além disso, ele contribui para a manutenção da homeostase metabólica por meio da ativação da transcrição dos genes responsáveis pelo balanço energético (KNOUFF; AUWERX, 2004) e repressão de genes relacionados ao processo inflamatório observado na resistência insulínica (TAVARES; HIRATA; HIRATA, 2007; SEMPLE; CHATTERJEE; O'RAHILLY, 2006).

Os glicocorticoides, agonistas endógenos do GR, desempenham um papel fundamental para a regulação de uma variedade de processos fisiológicos, dentre eles a modulação do sistema imune, a manutenção das concentrações de eletrólitos, da pressão arterial, da função 
cerebral e da regulação da proliferação e diferenciação celular (ODERMATT et al., 2006). O GR possui duas isoformas a $\alpha$ e a $\beta$; a isoforma beta é incapaz de ligar-se aos glicocorticoides e de ativar a transcrição gênica (FARIA; LONGUI, 2006).

A atividade do GR ocorre, pelo menos, em três níveis: (i) recrutamento dos fatores da maquinaria geral de transcrição; (ii) modulação da ação dos fatores de transcrição, independentemente da ligação ao DNA; e (iii) modulação da estrutura da cromatina, permitindo a ligação de outras proteínas reguladoras ao DNA (MCEWAN; WRIGHT; GUSTAFSSON, 1997; FARIA; LONGUI, 2006). Na ausência de ligação ao glicocorticoide, o GR encontra-se inativo no citoplasma, estabilizado por um complexo proteico denominado proteínas do choque térmico (heat shock proteins; hsp). (FARIA; LONGUI, 2006).

Após a ligação do glicocorticoide, o GR dissocia-se do complexo com as $h s p$, forma homodímeros com outras moléculas do receptor ativado, transloca-se para o núcleo, interage com o elemento responsivo aos glicocorticoides na sequência reguladora de seus genes-alvo, bem como com fatores de transcrição e, assim, modula a expressão do gene-alvo (FARIA; LONGUI, 2006). O GR é expresso em vários tecidos periféricos, incluindo tecidos chave para a regulação do metabolismo energético, como o fígado, músculo esquelético e tecido adiposo. Seus ligantes sintéticos incluem os glicocorticoides sintéticos, como a dexametasona, e seu principal uso clínico decorre de sua atividade anti-inflamatória e imunossupressora (PEEK et al., 2012). 


\section{OBJETIVO}

\subsection{OBJETIVO GERAL}

Investigar o potencial adipogênico do fluoreno, naftaleno, nonilfenol e procimidona em cultura de células.

\subsection{OBJETIVOS ESPECÍFICOS}

- Investigar o efeito do fluoreno, naftaleno, nonilfenol e procimidona sobre a viabilidade de células HeLa, por meio do ensaio de redução do MTT (brometo de 3-(4,5-dimetiltiazol-2-yl)2,5-difeniltetrazolio).

- Investigar a atividade agonista e antagonista do fluoreno, naftaleno, nonilfenol e procimidona nos receptores PPAR $\gamma$ e GR $\alpha$.

- Investigar o efeito do fluoreno, naftaleno, nonilfenol e procimidona sobre a diferenciação de pré-adipócitos murinos 3T3-L1 em adipócitos, em cultura de células.

- Investigar o efeito do fluoreno, naftaleno, nonilfenol e procimidona sobre a diferenciação de células mesenquimais murinas C3H10T1/2 em adipócitos, em cultura de células. 


\section{MATERIAL E MÉTODOS}

\subsection{REAGENTES}

Os reagentes utilizados neste estudo estão apresentados na Tabela 2.

Tabela 2 - Descrição da massa molecular e do fabricante dos reagentes utilizados neste estudo.

\begin{tabular}{lcc}
\hline Reagente & Massa molecular & Empresa fabricante \\
\hline Fluoreno & 166,22 & Sigma-Aldrich ${ }^{\circledR}$ \\
Naftaleno & 128,17 & Sigma-Aldrich ${ }^{\circledR}$ \\
Nonilfenol & 220,35 & Sigma-Aldrich ${ }^{\circ}$ \\
Procimidona & 284,14 & Sigma-Aldrich ${ }^{\circledR}$ \\
Rosiglitazona & 357,43 & Sigma-Aldrich ${ }^{\circledR}$ \\
Dexametasona & 392,46 & Sigma-Aldrich ${ }^{\circledR}$ \\
Isometilbutilxantina & 222,24 & Sigma-Aldrich ${ }^{\circledR}$ \\
Insulina & 5807,57 & Sigma-Aldrich ${ }^{\circledR}$ \\
Lipofectamina & - & Invitrogen ${ }^{\circledR}$ \\
Óleo Vermelho O & 408,49 & Sigma-Aldrich ${ }^{\circledR}$ \\
MTT & 335,43 & Sigma-Aldrich ${ }^{\circledR}$ \\
\hline
\end{tabular}

\subsection{CULTURA DE CÉLULAS}

Neste estudo, foram utilizadas células HeLa para os ensaios de gene repórter e células 3T3-L1 e C3H10T1/2 para os ensaios de adipogênese.

As células HeLa foram cultivadas em meio de cultura DMEM (Dulbecco's Modified Eagle Medium) contendo $2 \mathrm{nM}$ de glutamina, $100 \mathrm{U} / \mathrm{mL}$ de penicilina, $100 \mu \mathrm{g} / \mathrm{mL}$ de estreptomicina e $10 \%$ de soro fetal bovino, em placas de $150 \mathrm{~mm}$ para cultura de células (Corning®), e mantidas a $37^{\circ} \mathrm{C}$ e com $5 \%$ de $\mathrm{CO}_{2}$. 


\subsection{ENSAIO DE VIABILIDADE CELULAR}

O ensaio de redução do brometo de MTT (3-(4,5-dimetiltiazol-2-yl)-2,5difeniltetrazolio) é amplamente utilizado para a avaliação da viabilidade celular. O MTT em solução aquosa apresenta coloração amarelada e, quando reduzido por ação de desidrogenases mitocondriais e por agentes redutores produzidos como resultado do metabolismo de células ativas, forma um complexo insolúvel de coloração azul-violeta, que são os precipitados ou cristais de formazan. Como apenas células viáveis e metabolicamente ativas são capazes de reduzir o MTT em formazan, a quantidade de formazan formada é diretamente proporcional à viabilidade celular. (STOCKERT et al., 2012).

Células HeLa foram cultivadas em meio de cultura DMEM, em placas de 96 poços (3 x $10^{4}$ células por poço) e mantidas durante 24 horas em incubadora a $37^{\circ} \mathrm{C}$ e $5 \%$ de $\mathrm{CO}_{2}$. Depois desse período, foram tratadas com DMSO (veículo, controle negativo) ou concentrações crescentes dos DE fluoreno, naftaleno, nonilfenol e procimidona $\left(10^{-12} \mathrm{M}\right.$ a $10^{-}$ ${ }^{3} \mathrm{M}$, com diferença de concentração de dez vezes a cada concentração neste intervalo) e mantidas em incubadora a $37^{\circ} \mathrm{C}$ e $5 \%$ de $\mathrm{CO}_{2}$. Um grupo de células não recebeu tratamento, e a 3 poços da placa foi adicionado somente meio de cultura (branco). Após 24 horas, o meio de cultura foi cuidadosamente aspirado e foram adicionados, a cada poço, $80 \mu \mathrm{L}$ de meio de cultura e $8 \mu \mathrm{L}$ de solução de MTT a $5 \mathrm{mg} / \mathrm{mL}$. As células foram então mantidas em incubadora durante 4 horas a $37^{\circ} \mathrm{C}$ e $5 \%$ de $\mathrm{CO}_{2}$. Depois disso, foram adicionados $80 \mu \mathrm{L}$ de isopropanol acidificado a cada poço e os cristais formados foram homogeneizados até sua solubilização completa. A quantidade de formazan formada foi medida por meio da leitura da absorbância no comprimento de onda de $570 \mathrm{~nm}$, em leitor de microplacas (espectrofotômetro da marca Shimadzu). Três experimentos foram realizados em triplicata. A viabilidade celular foi determinada da seguinte forma:

(i) Do valor das absorbâncias obtidos nas amostras contendo células (não tratadas, tratadas com veículo ou com os DEs), foi subtraído o valor da absorbância obtido no branco (apenas meio de cultura);

(ii) Foi calculado o valor médio da absorbância de cada triplicata;

(iii) $\mathrm{O}$ valor médio da absorbância nas triplicatas tratadas com veículo ou DEs foi dividido pelo valor médio da absorbância na triplicata sem tratamento (apenas meio de cultura). O resultado foi expresso em percentual de viabilidade celular em 
relação ao grupo que não recebeu tratamento, em que se considerou haver viabilidade celular de $100 \%$.

\subsection{ENSAIO DE GENE REPÓRTER}

Para a avaliação da atividade dos compostos estudados nos receptores PPAR $\gamma$ e GR $\alpha$, foi utilizado o ensaio de transfecção por lipofectamina. A lipofectamina é uma formulação de moléculas lipídicas capazes de formar vesículas lipídicas, os lipossomos, em ambiente aquoso. Os lipossomos, por sua vez, apresentam capacidade de envolver o DNA plasmidial, facilitando a entrada do material genético dentro da célula, o que permite, assim, sua replicação ou expressão no meio intracelular.

Para o ensaio de gene repórter, células HeLa foram semeadas em placas de 48 poços e mantidas em cultura até que atingissem a confluência de aproximadamente 70\%. Em seguida, foi realizada a transfecção dos vetores de expressão do LBDPPAR $\gamma$-DBDGAL4 ou do GR $\alpha$ humanos e do plasmídeo repórter da luciferase com seus respectivos elementos responsivos (GAL ${ }_{5 x}$-Luc e GRE-Luc), utilizando o reagente Lipofectamine ® 2000 (Invitrogen), seguindo as instruções do fabricante. Para tanto, foram utilizados $300 \mathrm{ng}$ de DNA plasmidial por poço, na proporção de 1:4 entre o vetor de expressão do receptor nuclear e o elemento responsivo (60 ng do vetor de expressão do receptor + 240 ng do plasmídeo repórter contendo o elemento responsivo do receptor). Sendo assim, foram utilizadas as seguintes quantidades de plasmídeos: 60 ng de LBDPPAR $\gamma$-DBDGAL4 + 240 ng de GAL sx $_{\text {-Luc e }} 60$ ng de GR $\alpha+240$ ng de GRE-Luc.

Após 6 horas de incubação das células com a lipofectamina misturada ao DNA plasmidial, foram adicionados os tratamentos. Para investigação da atividade agonista nesses receptores nucleares, os tratamentos consistiram em:

(i) veículo (controle negativo, DMSO);

(ii) ligantes com atividade agonista conhecida nos dois receptores, como controles positivos (rosiglitazona na concentração de $10^{-5} \mathrm{M}$, agonista do PPAR $\gamma$; dexametasona na concentração de $10^{-5} \mathrm{M}$, agonista do GR $\alpha$ );

(iii) DE estudados em concentrações crescentes, de forma a elaborar uma curva concentração-resposta.

As concentrações crescentes dos DE foram selecionadas a partir dos resultados do ensaio de viabilidade celular (redução do MTT). As concentrações do fluoreno, do naftaleno e 
da procimidona utilizadas foram de $10^{-12} \mathrm{M}$ a $10^{-4} \mathrm{M}$ (crescentes, nesta faixa, em intervalos de 10 vezes). $\mathrm{O}$ nonilfenol foi utilizado em concentrações variando entre $10^{-12} \mathrm{M}$ a $10^{-5} \mathrm{M}$ (também crescentes nesta faixa, em intervalos de 10 vezes).

Após 24 horas do tratamento com o veículo ou os ligantes, as células foram lisadas com tampão apropriado e foi adicionado o substrato da luciferase, a luciferina (Promega ${ }^{\circledR}$ ). A luciferase catalisa a conversão da luciferina em oxiluciferina e nesta reação é gerada luz. A quantidade de luz gerada, proporcional à atividade da enzima, pode ser detectada por um luminômetro, de forma que a medida da atividade da luciferase foi realizada em luminômetro (Turner $\AA$ ). Todos os experimentos foram realizados em triplicata e repetidos pelo menos 2 vezes.

As concentrações crescentes dos DE foram selecionadas a partir dos resultados do ensaio de viabilidade celular (redução do MTT). As concentrações do fluoreno, do naftaleno e da procimidona utilizadas foram de $10^{-12} \mathrm{M}$ a $10^{-4} \mathrm{M}$ (crescentes, nesta faixa, em intervalos de 10 vezes). O nonilfenol foi utilizado em concentrações variando de $10^{-12} \mathrm{M}$ a $10^{-5} \mathrm{M}$ (também crescentes nesta faixa, em intervalos de 10 vezes).

Para testar o antagonismo dos DE estudados no PPAR $\gamma$, as células foram tratadas da seguinte forma, durante 4 horas, com DMSO, naftaleno $\left(10^{-5} \mathrm{M}\right.$ e $\left.10^{-4} \mathrm{M}\right)$, nonilfenol $\left(10^{-6} \mathrm{e}\right.$ $\left.10^{-5} \mathrm{M}\right)$ e procimidona $\left(10^{-5}\right.$ e $\left.10^{-4} \mathrm{M}\right)$. Depois desse período, as células foram tratadas com rosiglitazona $10^{-6} \mathrm{M}$. Nesta etapa, o grupo tratado com DMSO foi dividido em dois subgrupos: um subgrupo foi mantido com o tratamento com DMSO e o outro recebeu rosiglitazona $10^{-6}$ M.

Após 24 horas do tratamento com o veículo ou os ligantes, as células foram lisadas $\mathrm{cm}$ tampão apropriado e foi adicionado o substrato da luciferase, a luciferina (Promega). A luciferase catalisa a conversão da luciferina em oxiluciferina e nesta reação é gerada luz. A quantidade de luz gerada, proporcional à atividade da enzima, pode ser detectada por um luminômetro, de forma que a detecção da atividade da luciferase foi realizada em luminômetro (Turnerâ). Todos os experimentos foram realizados em triplicata e repetidos pelo menos 3 vezes. Nos ensaios de agonismo e antagonismo, foi calculada a taxa de ativação do receptor por meio da divisão entre a atividade de luciferase no grupo tratado com compostos (rosiglitazona, dexametasona ou DE) e no grupo tratado com veículo (DMSO). 


\subsection{ENSAIO DE ADIPOGÊNESE EM CULTURA DE CÉLULAS}

O processo de adipogênese é avaliado com o estudo de alguns tipos celulares que podem ser induzidos, em cultura, a diferenciar-se em adipócitos. O primeiro e melhor caracterizado modelo de adipogênese é a linhagem celular 3T3-L1, uma subcepa da linhagem 3T3 do camundongo Swiss, comprometida com a diferenciação adipocitária (GREEN; MEUTH, 1974). Os pré-adipócitos 3T3-L1, cultivados em condições habituais, apresentam a morfologia de fibroblastos. Quando tratados com substâncias que iniciam a cascata transcricional envolvida na adipogênese, adotam o formato arredondado, e em cinco dias iniciam acúmulo de lipídeos, que aparecem como gotículas intracelulares, um fenótipo compatível com o do adipócito diferenciado. As substâncias capazes de induzir a adipogênese são a isometilbutilxantina (IBMX, um inibidor de fosfodiesterase que aumenta a concentração intracelular de AMP cíclico), a dexametasona (um agonista do GR) e a insulina.

Células mesenquimais também podem ser induzidas a se diferenciar em cultura. A linhagem de células mesenquimais $\mathrm{C} 3 \mathrm{H} 10 \mathrm{~T} 1 / 2$ foi isolada de embriões de camundongos $\mathrm{C} 3 \mathrm{H}$ com 14 a 17 dias, e apresenta morfologia de fibroblastos em cultura. Essa linhagem é funcionalmente semelhante a células tronco mesenquimais e também pode ser induzida a diferenciar-se em adipócitos em resposta ao tratamento com a combinação de dexametasona, IBMX e insulina (OTTO; LANE, 2005).

Cada componente da combinação dexametasona, IBMX e insulina ativa vias celulares específicas, importantes para a diferenciação adipocitária. A dexametasona ativa o fator de transcrição $\mathrm{C} / \mathrm{EBP} \beta$, e a IBMX inibe fosfodiesterases de nucleotídeos cíclicos, o que resulta em aumento dos níveis intracelulares de AMPc e ativação do fator de transcrição $\mathrm{C} / \mathrm{EBP} \delta$. $\mathrm{O}$ $\mathrm{C} / \mathrm{EBP} \beta$ e o $\mathrm{C} / \mathrm{EBP} \delta$, por sua vez, induzem a transcrição do $\mathrm{C} / \mathrm{EBP} \alpha$ e do PPAR $\gamma$. A insulina contribui para a diferenciação de adipócitos por ativar a expressão de genes específicos desse tipo celular, como o que codifica a síntese de AG, a proteína ligadora de AG (FABP), a leptina e a adiponectina (ROSEN et al., 2000). A mistura dexametasona, IBMX e insulina constitui um forte indutor de adipogênese para as células 3T3-L1, já comprometidas com a diferenciação adipocitária. Estas células podem ser induzidas a se diferenciar também com tratamento apenas com insulina; o meio indutor contendo insulina, mas não IBMX e dexametasona, é considerado um indutor menos acentuado da diferenciação adipocitária.

Os experimentos foram realizados com ambas as linhagens celulares, pré-adipócitos 3T3-L1 e células mesenquimais C3H10T1/2, que foram cultivadas em placas de $150 \mathrm{~mm}$ para cultura de células (Corning®), em meio DMEM contendo soro neonatal bovino a $10 \%$, até 
sua subconfluência. Depois disso, as células foram plaqueadas em placas de 12 poços até sua confluência. Dois dias depois de observada a confluência, foram induzidas a se diferenciar em adipócitos.

As células 3T3-L1 foram induzidas a se diferenciar em adipócitos com insulina (10 $\mathrm{mg} / \mathrm{mL}$ ), durante 4 dias , e as células C3H10T1/2, com 0,5 $\mathrm{nM}$ de IBMX, $1 \mu \mathrm{g} / \mathrm{mL}$ de insulina e $1 \mu \mathrm{M}$ de dexametasona também durante 4 dias. Em seguida, foram mantidas com $1 \mu \mathrm{g} / \mathrm{mL}$ de insulina por 6 dias. Durante todo período, foram cultivadas em meio DMEM contendo soro fetal bovino a $10 \%$ e submetidas a tratamentos com veículo (DMSO, controle negativo), rosiglitazona (controle positivo) ou os DEs testados, nas concentrações em que não se mostraram citotóxicos:

(i) fluoreno: $10^{-12}$ a $10^{-4} \mathrm{M}$, com intervalos de 10 vezes;

(ii) naftaleno: $10^{-12}$ a $10^{-4} \mathrm{M}$, com intervalos de 10 vezes;

(iii) nonilfenol: $10^{-12}$ a $10^{-5} \mathrm{M}$, com intervalos de 10 vezes;

(iv) procimidona: $10^{-12}$ a $10^{-4} \mathrm{M}$, com intervalos de 10 vezes.

A adipogênese foi avaliada pela coloração com o corante de lipídeos neutros óleo vermelho $\mathrm{O}$.

A partir dos experimentos realizados com 9 concentrações dos DEs testados e analisados por meio da coloração com o óleo vermelho $\mathrm{O}$, foram selecionadas 3 concentrações de cada DE, correspondentes aos resultados de maior acúmulo lipídico. Estas concentrações foram então utilizadas para uma segunda etapa de ensaios de diferenciação, conduzidos de acordo com o mesmo protocolo acima descrito, em placas de 6 poços. Ao final do período de diferenciação, as células foram coradas com o óleo vermelho $\mathrm{O}$ para a obtenção de fotografias, ou o RNA total foi extraído para a quantificação da expressão do RNAm da proteína ligadora de ácidos graxos adipocitária (aP2 ou FABP, fatty acid binding protein), um marcador de adipócitos diferenciados.

Foram realizados 3 ensaios de diferenciação de adipócitos independentes com cada uma das linhagens celulares.

\subsubsection{Coloração por óleo vermelho O}

Após o período de diferenciação, as células foram lavadas com tampão PBS duas vezes e fixadas com formaldeído $4 \%$ em tampão PBS, durante 40 minutos. Após a fixação, foram lavadas duas vezes com água destilada e mais duas vezes com tampão PBS e então 
coradas com solução de óleo vermelho O (0,5\% em isopropanol 60\%) durante 1 hora. Após a coloração, foram lavadas em água corrente e fotografadas com magnificação de 20 e de 10 vezes. As células foram consideradas diferenciadas quando apresentassem gotículas de lipídeos, evidenciadas na cor vermelha.

\subsubsection{Avaliação da expressão do RNAm da FABP-A}

Para a avaliação da expressão do RNAm do gene que codifica a FAPB-A, foi extraído o RNA total das células 3T3-L1 e C3H10T1/2 induzidas a se diferenciar em adipócitos na presença dos controles ou dos diferentes DE, e realizada a reação em cadeia de polimerase (PCR, polymerase chain reaction) com a utilização do kit Power SYBR ${ }^{\circ}$ Green RNA-to-

$\mathrm{CT}^{\mathrm{TM}}$ 1-Step kit (Applied Biosystems), que permite a realização, em uma única etapa, da transcrição reversa do RNA mensageiro em DNA complementar e a PCR quantitativa.

A extração do RNA total das células foi realizada com o reagente TRIzol® (Invitrogen), de acordo com as recomendações do fabricante. Para isso, o meio de cultura das células foi descartado e as placas lavadas 2 vezes com PBS e mantidas sobre o gelo. Foi acrescentado $1 \mathrm{~mL}$ de TRIzol a cada poço da placa de 6 poços. E em seguida, as células foram removidas com o auxílio de uma micropipeta e a suspensão de células em Trizol foi transferida para tubos de 1,5 mL e mantida a temperatura ambiente durante 5 minutos. Depois disso, os tubos foram centrifugados a $14000 \mathrm{rpm}$, por 10 minutos, a $4^{\circ} \mathrm{C}$, para remoção de debris celulares, que formaram um pellet. O sobrenadante foi então transferido para outros tubos de 1,5 mL, e foram adicionados $200 \mu \mathrm{L}$ de clorofórmio (Sigma Aldrich). A mistura foi então homogeneizada em agitador de tubos (vortex) e incubada por 3 minutos a temperatura ambiente. Foi então realizada centrifugação para separação das fases (14000 rpm, 15 minutos, $4^{\circ} \mathrm{C}$ ). A fase aquosa (que ocupa a posição superior apos o centrifugação), que contem o RNA total, foi transferida para novos tubos de $1,5 \mathrm{~mL}$, aos quais foram adicionados $500 \mu \mathrm{L}$ de isopropanol (J.T.Baker®) para precipitação do RNA. Os tubos foram incubados durante 10 minutos a temperatura ambiente e então centrifugados a $14000 \mathrm{rpm}$, por 10 minutos, a $4^{\circ} \mathrm{C}$ ). O pellet formado foi lavado com etanol (J.T.Baker®) a 75\% (v/v), novamente centrifugado (9000 rpm, 5 minutos, $4^{\circ} \mathrm{C}$ ), seco a temperatura ambiente e ressuspendido em $50 \mu \mathrm{L}$ de água milli-Q estéril tratada com $0,1 \%(\mathrm{p} / \mathrm{v})$ de dietilpirocarbonato (DEPC) (Sigma Aldrich). As amostras foram armazenadas em freezer a $80^{\circ} \mathrm{C}$ negativos até o momento do uso. 
A quantificação e o grau de pureza das amostras de RNA total foram determinados no espectrofotômetro NanoVue Plus (GE Healthcare Life Sciences), com a utilização de $1 \mu \mathrm{L}$ das amostras. A quantificação foi realizada no comprimento de onda de $260 \mathrm{~nm}$ e expressa em $\mathrm{mg} / \mathrm{mL}$. O grau de contaminação por proteínas foi verificado por meio da razão entre os comprimentos de onda $260 \mathrm{~nm}$ e $280 \mathrm{~nm}$; as razões entre 1,7 e 2,2 foram consideradas adequadas com relação à pureza.

A integridade do RNA total foi verificada por eletroforese em gel de agarose a $1 \%$ (p/v) em tampão TBE 1x (Tris-borato-EDTA). O gel foi corado com brometo de etídeo (0,5 $\mathrm{mg} / \mathrm{mL}$ em água destilada) e examinado sob luz ultravioleta (UV) a fim de se avaliar a qualidade das subunidades $28 \mathrm{~s}$ e $18 \mathrm{~s}$ do RNA ribossomal. As amostras consideradas satisfatórias (pureza e integridade adequadas) foram tratadas com DNAse I (Sigma-Aldrich) com o objetivo de eliminar possíveis contaminações com DNA genômico. Para tanto, alíquotas contendo $1 \mu \mathrm{g}$ de RNA total foram tratadas com 1 unidade de DNAse I (Sigma Aldrich) durante 15 minutos a temperatura ambiente. Em seguida, a enzima foi inativada com uma solução contendo EDTA $(50 \mathrm{mM})$. Esse procedimento foi feito de acordo com o protocolo do fabricante da enzima.

Depois de tratado com DNAse, o RNA foi utilizado para determinação da expressão relativa de FABP-A em cada uma das amostras. Como mencionado anteriormente, foi utilizado o kit Power SYBR ${ }^{\circledR}$ Green RNA-to-C ${ }_{\mathrm{T}}$ 1-Step (Applied Biosystems), em que as reações de transcrição reversa e em cadeia da polimerase são realizadas sequencialmente e sem necessidade de manipulação das amostras entre elas (daí a denominação do kit de "1Step"). O produto de amplificação de cada amostra foi determinado pela utilização do SYBR Green, um fluoróforo que se intercala na dupla fita de DNA e, quando excitado por luz, emite fluorescência, de forma que a intensidade do sinal fluorescente é diretamente proporcional à quantidade do produto de amplificação na amostra, a cada ciclo da PCR. O sinal fluorescente é detectado por um detector no equipamento de PCR e, ao final da reação, é possível determinar o $\mathrm{Ct}$ (cycle threshold / ciclo limiar), que corresponde ao número de ciclos de reação necessários para a amplificação tornar-se exponencial.

As reações foram preparadas em placas de 96 poços (MicroAmp Optical, Applied Biosystems), para volume final de $10 \mu \mathrm{L}$ por reação, da seguinte forma: 0,08 $\mu \mathrm{L}$ de Mix da enzima transcriptase reversa, RT (125x), $5 \mu \mathrm{L}$ de Mix Power SYBR ${ }^{\circledR}$ Green RT-PCR (2x), 0,2 $\mu \mathrm{L}$ de cada primer (concentração inicial de $5 \mu \mathrm{M}$ ) e 5 ng de RNA e água livre de RNAse e DNAse (para completar o volume para $10 \mu \mathrm{L}$ ). Uma reação sem amostra de RNA (controle 
negativo) e sem transcriptase reversa foi realizada para cada par de primer, a fim de se verificarem possíveis contaminações. Foram utilizados os primers específicos para o DNAc do gene que codifica a FABP-A e o gene referência Gapdh, cujas sequências estão descritas na Tabela 3.

Tabela 3 - Sequência dos primers utilizados na PCR em tempo real.

\begin{tabular}{ccc}
\hline Gene & Primer forward & Primer reverse \\
\hline Fabpa & 5'-ACACCGAGATTTCCTTCAAAC-3' & 5'-CCATCTAGGGTTATGATGCTCTTCA-3' \\
Gapdh & 5'AAGGGCTCATGACCACAGTC-3' & 5'-CAGGGATGATGTTCTGGGCA-3' \\
\hline
\end{tabular}

As reações foram conduzidas no equipamento Applied Biosystems StepOnePlus ${ }^{\mathrm{TM}}$ Real-Time PCR Systems e os dados obtidos foram analisados com o programa Software StepOne v2.1. As condições da reação foram: 30 minutos a $48^{\circ} \mathrm{C}$ para realização da reação de transcrição reversa; 10 minutos a $95^{\circ} \mathrm{C}$ para ativação da enzima DNA polimerase; 40 ciclos de $95^{\circ} \mathrm{C}$ por 15 segundos para desnaturação e $60^{\circ} \mathrm{C}$ por 1 minuto para anelamento e extensão. Em seguida, foi realizada a curva de desnaturação dos produtos de reação para determinação da especificidade do produto, por meio da avaliação da Tm (temperatura de desnaturação), que representa a temperatura em que $50 \%$ do produto de PCR encontra-se desnaturado. A Tm é específica para cada sequência de DNA amplificada e, assim, permite a determinação da especificidade do produto da reação.

Depois de finalizadas as reações, foram obtidos os valores de Ct relativos a cada uma das amostras (tratadas com veículo, controle positivo ou DEs). Os valores de Ct nas reações de amplificação do DNA complementar do gene que codifica a FABP-A (gene alvo) foram normalizados em função dos valores obtidos nas reações em que foi amplificado o DNA complementar do gene referência (Gapdh), por meio da subtração do $\mathrm{Ct}$ do gene alvo pelo $\mathrm{Ct}$ do gene referência $(\Delta \mathrm{Ct})$. A quantificação relativa da expressão do DNA complementar do gene que codifica a FABP-A foi feita utilizando-se o método de comparação de $\mathrm{Ct}$ ou $\Delta \Delta \mathrm{Ct}$, segundo o qual a expressão relativa do gene corresponde ao valor obtido pela fórmula aritmética $2^{-\Delta \Delta \mathrm{Ct}}$, onde $\Delta \Delta \mathrm{Ct}=\Delta \mathrm{Ct}$ amostras $-\Delta \mathrm{Ct}$ calibrador, e o calibrador corresponde às amostras tratadas com veículo. 


\subsection{ANÁLISE ESTATÍSTICA}

Os resultados do ensaio de viabilidade celular foram apresentados como média \pm erro padrão da média (EPM) da viabilidade celular das células tratadas com os DE testados em relação às células tratadas com veículo (em termos percentuais). Os resultados dos ensaios de gene repórter foram apresentados como média \pm EPM da taxa de ativação da transcrição dos grupos tratados com o controle positivo ou com os DE, em relação ao grupo tratado com veículo (controle). O teste estatístico empregado, nos dois casos, foi a análise de variância (ANOVA), seguida da comparação múltipla de Newman-Keuls.

Os resultados da expressão relativa do gene que codifica a FABP-A ou aP2 também foram apresentados como média \pm EPM da expressão nos grupos tratados com o controle positivo ou com os $\mathrm{DE}$, em relação ao grupo tratado com veículo (controle) e para comparação entre grupos foi empregado o teste de Kruskal-Wallis seguido do teste de Dunn.

Todas as análises foram realizadas por meio da utilização do programa GraphPad Prism versão 5.0 para Windows. O critério de significância para todas as análises foi o valor $p$ $<0,05$. 


\section{RESULTADOS}

\subsection{EFEITO DO FLUORENO, NAFTALENO, NONILFENOL E PROCIMIDONA SOBRE A VIABILIDADE CELULAR}

Primeiramente, foi investigada a viabilidade de células HeLa tratadas com concentrações crescentes do fluoreno, naftaleno, nonilfenol e procimidona para definir as concentrações dos compostos que não comprometessem a viabilidade celular e, assim, pudessem ser utilizadas nos próximos experimentos. Os resultados da viabilidade celular em resposta às diferentes concentrações dos compostos estudados estão apresentados na Figura 8. Após 24 horas de tratamento, nenhuma das concentrações testadas de fluoreno, de naftaleno e procimidona comprometeu a viabilidade celular. Entretanto, foi observada redução acentuada da viabilidade celular em resposta às duas maiores concentrações testadas de nonilfenol $\left(10^{-4}\right.$ $\left.\mathrm{M} \mathrm{e} 10^{-3} \mathrm{M}\right)$.
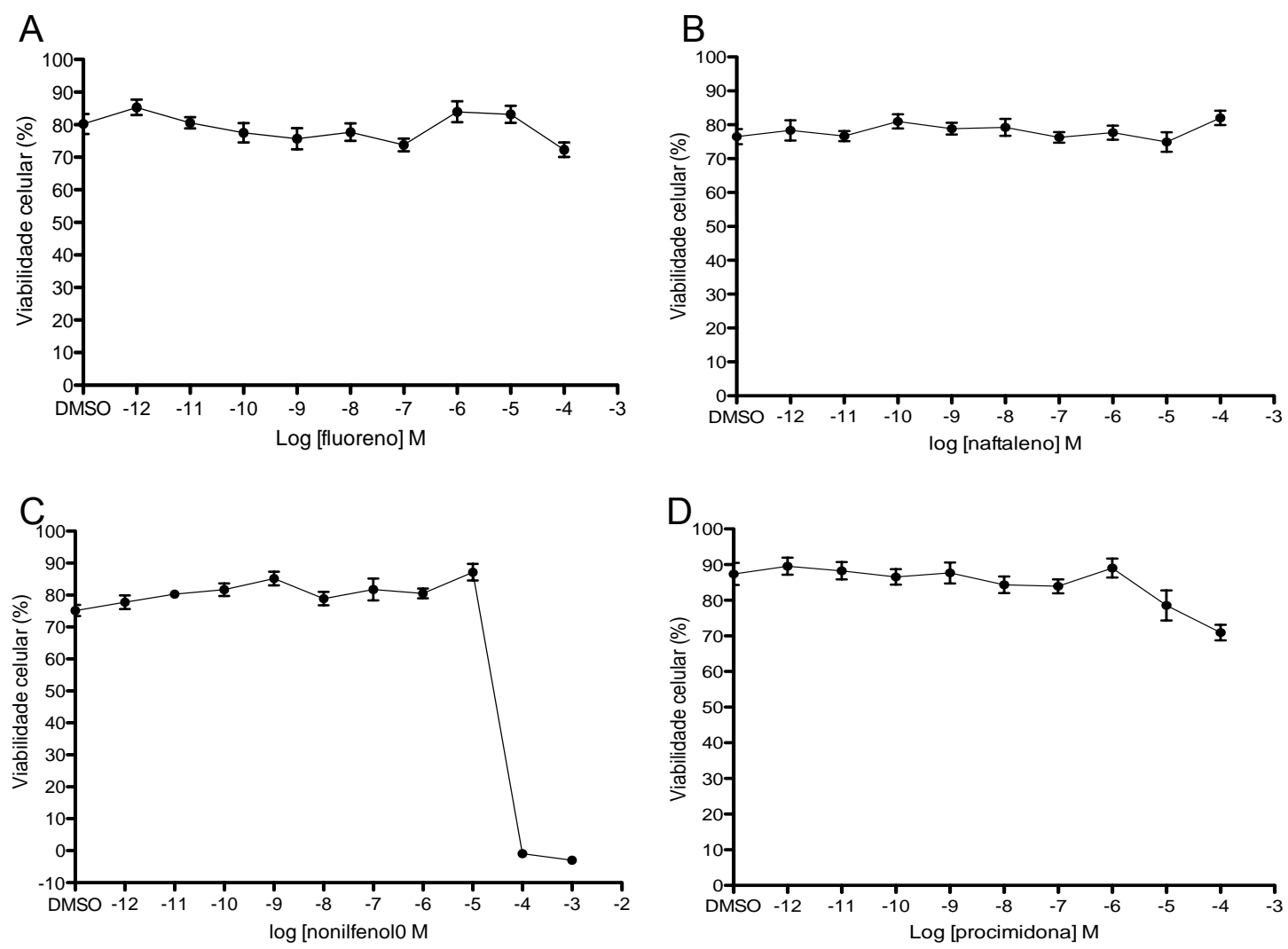

Figura 8 - Ensaio de viabilidade celular. Células HeLa tratadas com veículo ou concentrações crescentes de (A) fluoreno, (B) naftaleno, (C) nonilfenol e (D) procimidona e avaliadas quanto à capacidade de redução do MTT a formazan. Viabilidade celular determinada como valor percentual em relação ao grupo que não recebeu tratamento, considerado como viabilidade celular de 100\%. Dados apresentados como média \pm EPM de três experimentos independentes realizados em triplicata. 


\subsection{INVESTIGAÇÃO DO EFEITO DO FLUORENO, DO NAFTALENO, DO} NONILFENOL E DA PROCIMIDONA SOBRE A ATIVIDADE TRANSCRICIONAL DO $\operatorname{PPAR} \gamma$

Todos os quatro DE foram investigados quanto à sua capacidade de ativar o PPAR $\gamma$, fator de transcrição envolvido no processo de adipogênese. Para isso, células HeLa foram cotransfectadas com o vetor quimérico contendo o LBD do PPAR $\gamma$ fusionado ao DBD do fator de transcrição de leveduras GAL4 e um plasmídeo contendo a sequência do repórter luciferase dirigida por 5 cópias do elemento responsivo ao GAL4 (GAL Gx $\left._{\mathrm{x}}-\mathrm{Luc}\right)$. O fator de transcrição GAL é exclusivo de leveduras e, assim, não é ativado por receptores endógenos de células de mamíferos. Desta forma, permite avaliar o efeito de compostos teste sobre o LBD do PPAR $\gamma$ isoladamente.

Para investigação da capacidade agonista dos desreguladores endócrinos, as células foram tratadas com concentrações crescentes de fluoreno, naftaleno, nonilfenol e procimidona, ou com concentrações crescentes de rosiglitazona (controle positivo). Como esperado, a rosiglitazona induziu, de forma concentração-dependente, a atividade transcricional do PPAR $\gamma$ (Figura 9). O fluoreno, naftaleno, nonilfenol e a procimidona foram testados até a concentração máxima em que não comprometeram a viabilidade celular (Figura 9) e não apresentaram atividade agonista no PPAR $\gamma$ (Figuras 9, 10, 11 e 12).

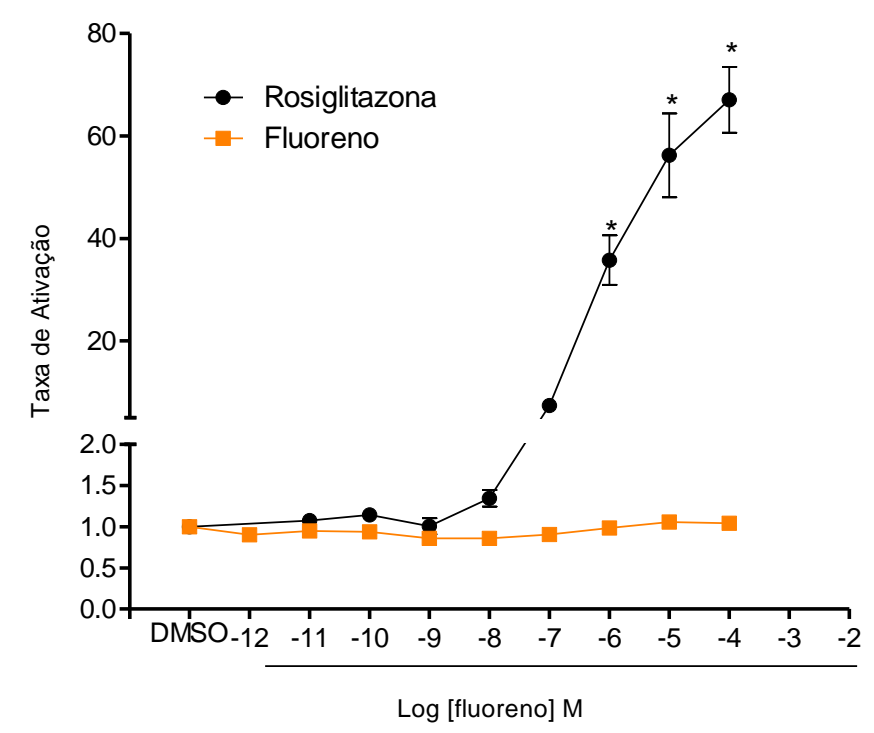

Figura 9.- O fluoreno não apresenta atividade agonista em PPAR $\gamma$. Células HeLa cotransfectadas com o

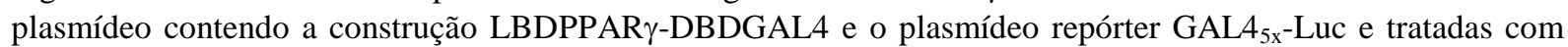
veículo (DMSO), concentrações crescentes de rosiglitazona ou fluoreno durante 24 horas e, em seguida, coletadas para avaliação da atividade da luciferase. Dados expressos como média \pm EPM da taxa de ativação da transcrição em relação ao veículo (DMSO), de 2 experimentos independentes realizados em triplicata. * significativamente diferente $(\mathrm{p}<0,05)$ do veículo (DMSO), por análise de variância (ANOVA) seguida do teste de Newman-Keuls. 


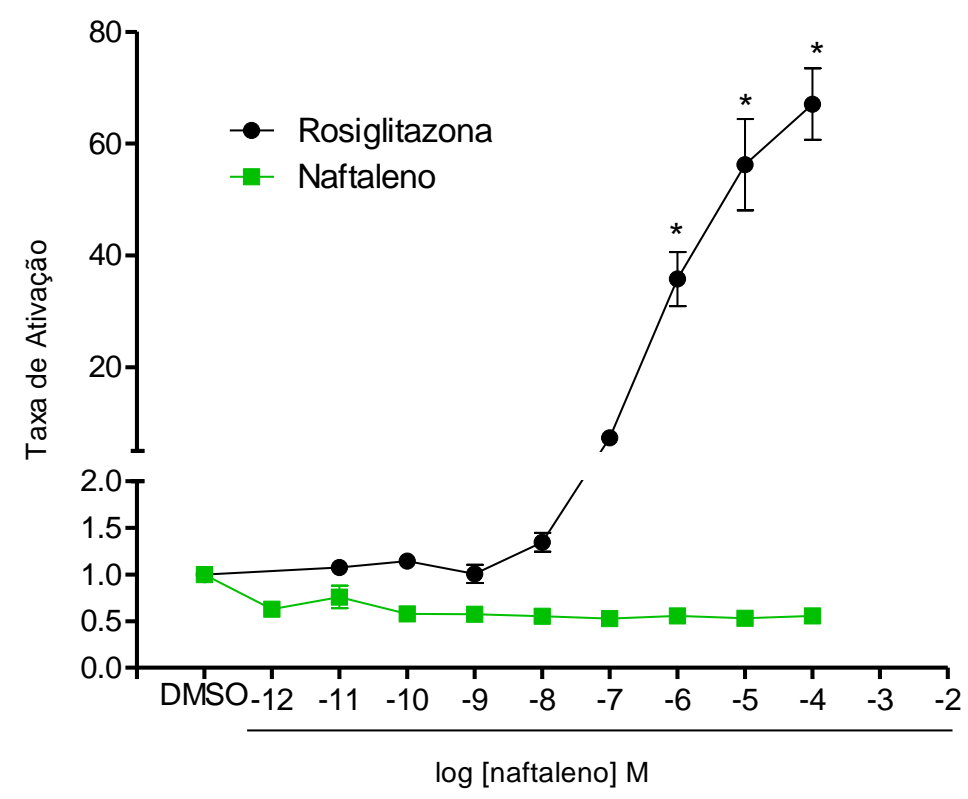

Figura 10 - O naftaleno não apresenta atividade agonista em PPAR $\gamma$. Células HeLa cotransfectadas com o plasmídeo contendo a construção LBDPPAR $\gamma$-DBDGAL4 e o plasmídeo repórter GAL4 $4_{5 \mathrm{x}}$-Luc e tratadas com veículo (DMSO), concentrações crescentes de rosiglitazona ou naftaleno durante 24 horas e, em seguida, coletadas para avaliação da atividade da luciferase. Dados expressos como média \pm EPM da taxa de ativação da transcrição em relação ao veículo (DMSO), de 2 experimentos independentes realizados em triplicata. * significativamente diferente $(\mathrm{p}<0,05)$ do veículo (DMSO), por análise de variância (ANOVA) seguida do teste de Newman-Keuls.

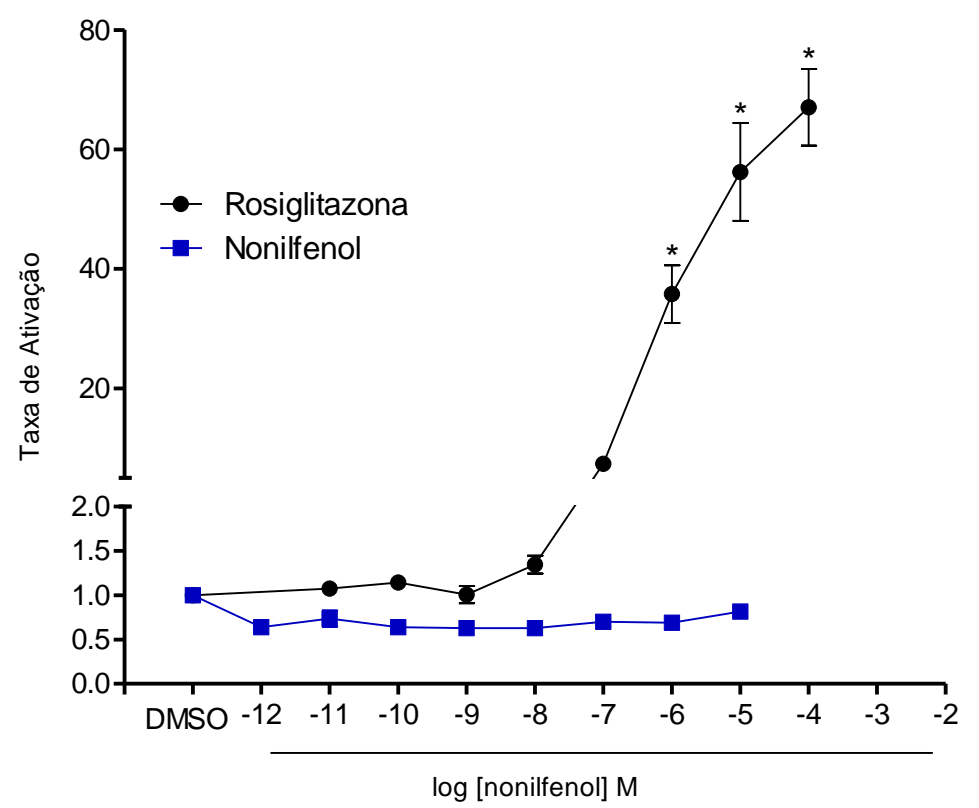

Figura 11 - O nonilfenol não apresenta atividade agonista em PPAR $\gamma$. Células HeLa cotransfectadas com o plasmídeo contendo a construção LBDPPAR $\gamma$-DBDGAL4 e o plasmídeo repórter GAL4 ${ }_{5 \mathrm{x}}$-Luc e tratadas com veículo (DMSO), concentrações crescentes de rosiglitazona ou nonilfenol durante 24 horas e, em seguida, coletadas para avaliação da atividade da luciferase. Dados expressos como média \pm EPM da taxa de ativação da transcrição em relação ao veículo (DMSO), de 2 experimentos independentes realizados em triplicata. * significativamente diferente ( $\mathrm{p}<0,05$ ) do veículo (DMSO), por análise de variância (ANOVA) seguida do teste de Newman-Keuls. 


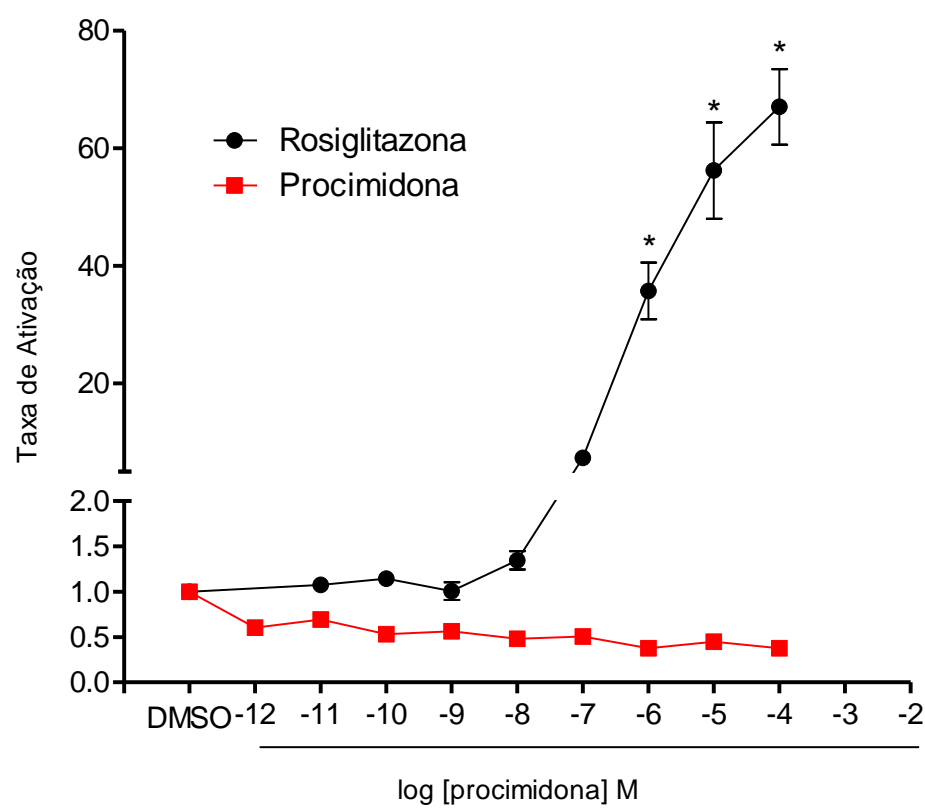

Figura 12 - A procimidona não apresenta atividade agonista em PPAR $\gamma$. Células HeLa cotransfectadas com o plasmídeo contendo a construção LBDPPAR $\gamma$-DBDGAL4 e o plasmídeo repórter GAL4 ${ }_{5 x}$-Luc e tratadas com veículo (DMSO), concentrações crescentes de rosiglitazona ou procimidona durante 24 horas e, em seguida, coletadas para avaliação da atividade da luciferase. Dados expressos como média \pm EPM da taxa de ativação da transcrição em relação ao veículo (DMSO), de 2 experimentos independentes realizados em triplicata. * significativamente diferente $(\mathrm{p}<0,05)$ do veículo (DMSO), por análise de variância (ANOVA) seguida do teste de Newman-Keuls.

Os resultados apresentados nas Figuras 10, 11 e 12 sugeriram leve redução da taxa de ativação da transcrição em resposta ao tratamento com as maiores concentrações de naftaleno, nonilfenol e procimidona, respectivamente. Para determinar se estes DE apresentavam atividade antagonista no PPAR $\gamma$, foi realizado o ensaio de antagonismo do receptor, em que se investigou a capacidade da concentração mais elevada de cada composto, testada no ensaio de agonismo, de reduzir a ativação da transcrição mediada pela rosiglitazona. Não foi observada atividade antagonista de nenhum dos 3 compostos (Figura 13). 


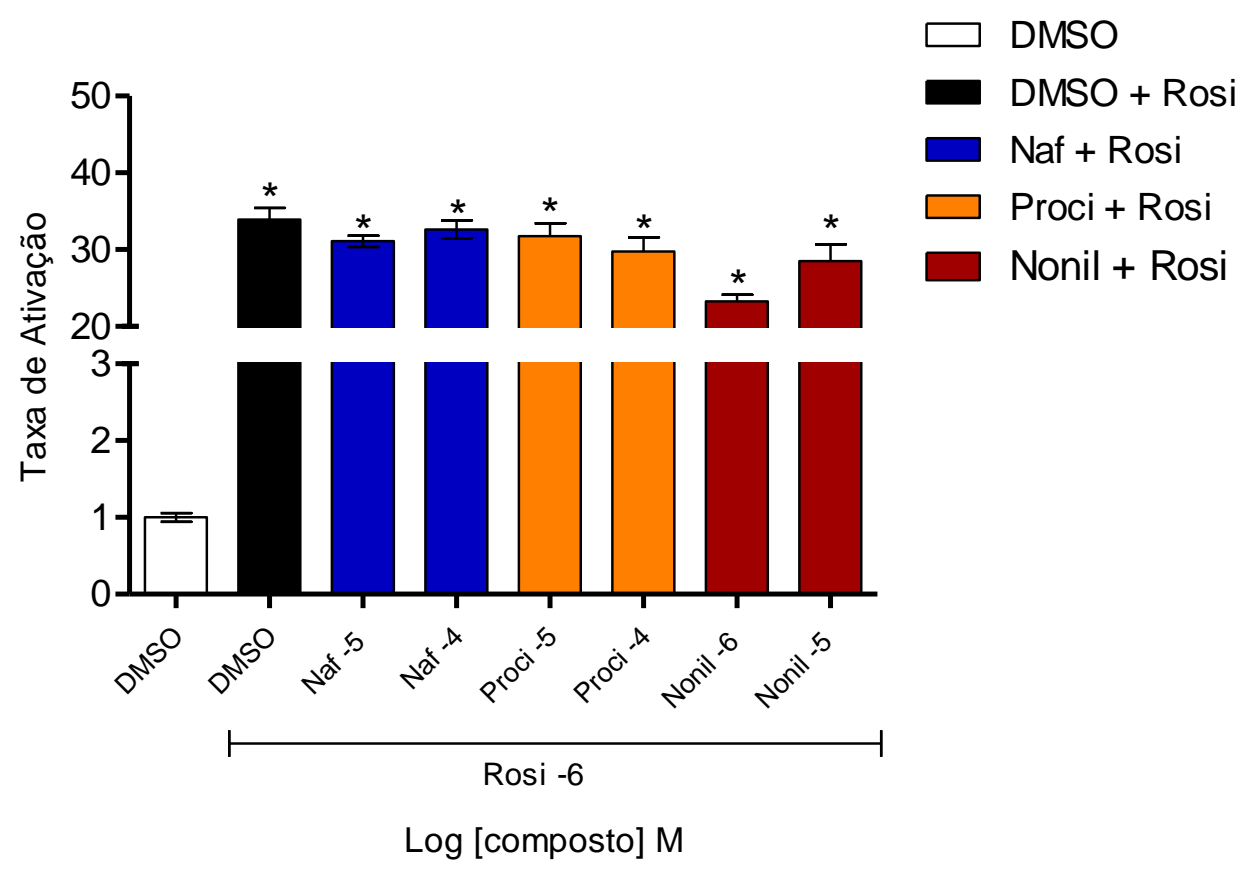

Figura 13 - O naftaleno, nonilfenol e procimidona não apresentam atividade antagonista em PPAR $\gamma$ Células HeLa cotransfectadas com o plasmídeo contendo a construção LBDPPAR $\gamma$-DBDGAL4, tratadas com rosiglitazona $10 \mu \mathrm{M}$ durante 8 horas e, em seguida, com veículo (DMSO) ou com as concentrações de naftaleno, nonilfenol ou procimidona indicadas durante 24 horas, e lisadas para determinação da atividade da luciferase. Dados apresentados como média \pm EPM de dois experimentos independentes realizados em triplicata. * significativamente diferente do veículo (DMSO) pela análise de variância (ANOVA) seguida do teste de Newman-Keuls. Naf: naftaleno; proci: procimidona; nonil: nonilfenol.

Esses resultados, em conjunto, mostraram que o fluoreno, naftaleno, nonilfenol e procimidona não possuem atividade agonista em PPAR $\gamma$. E, ainda, que o naftaleno, nonilfenol e procimidona não exercem atividade antagonista neste receptor.

\subsection{INVESTIGAÇÃO DA ATIVIDADE DO FLUORENO, NAFTALENO, NONILFENOL E PROCIMIDONA SOBRE A ATIVIDADE TRANSCRICIONAL DO GR $\alpha$}

A maioria dos DE possui capacidade de se ligar a diversos receptores nucleares. Considerando que no processo de adipogênese há vários receptores envolvidos, foi investigado se os DE estudados apresentavam atividade em outro receptor chave da diferenciação de adipócitos, o GR $\alpha$. Para isso, células HeLa foram cotransfectadas com vetor de expressão do GR $\alpha$ humano e o gene repórter luciferase dirigido pelo elemento responsivo ao GR $\alpha$ (GRE-Luc), e tratadas com veículo, concentrações crescentes de dexametasona (controle positivo) ou dos DE, estas últimas definidas a partir do ensaio de viabilidade celular 
(Figura 8). Como esperado, a dexametasona induziu a atividade transcricional do GR $\alpha$ de forma concentração-dependente. Não foi observada atividade agonista do fluoreno (Figura 14), naftaleno (Figura 15), nonilfenol (Figura 16) ou procimidona (Figura 17) no GR $\alpha$.

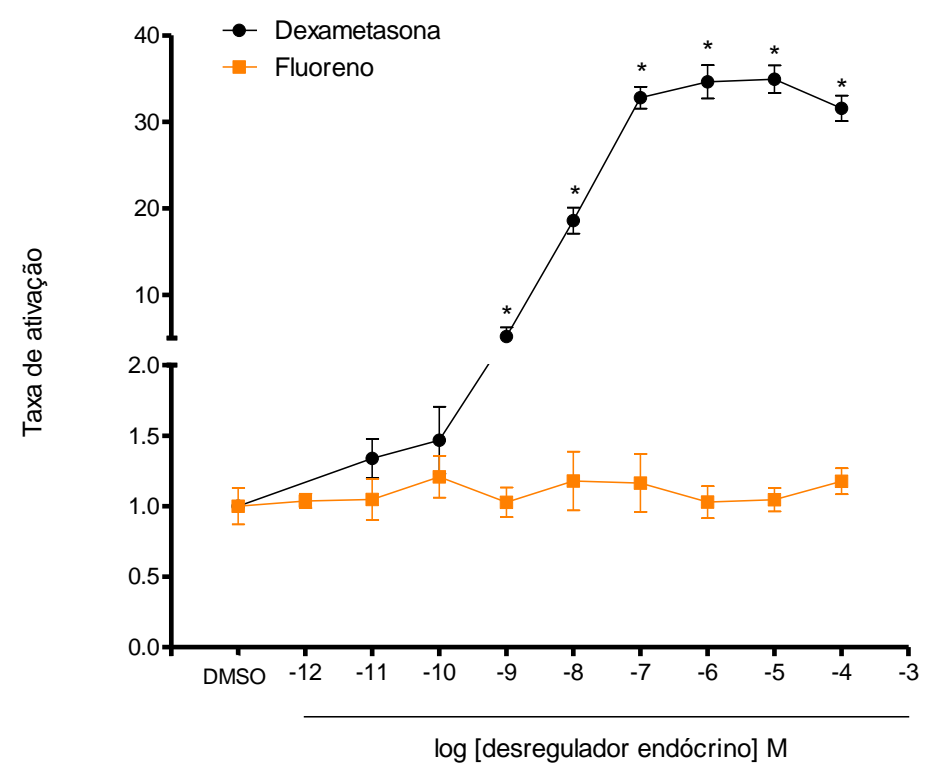

Figura 14 - O fluoreno não apresenta atividade agonista em GR $\alpha$. Células HeLa cotransfectadas com vetor de expressão do GR $\alpha$ humano e com o gene repórter luciferase dirigido pelo elemento responsivo ao (GRE-Luc) e tratadas com veículo (DMSO), dexametasona (controle positivo) ou fluoreno, durante $24 \mathrm{~h}$, e em seguida lisadas para determinação da atividade de luciferase. Dados expressos como média \pm EPM da taxa de ativação da transcrição em relação ao veículo DMSO, de 2 experimentos independentes realizados em triplicata. * Significativamente diferente do veículo pela análise de variância (ANOVA) seguida pelo teste de NewmanKeuls.

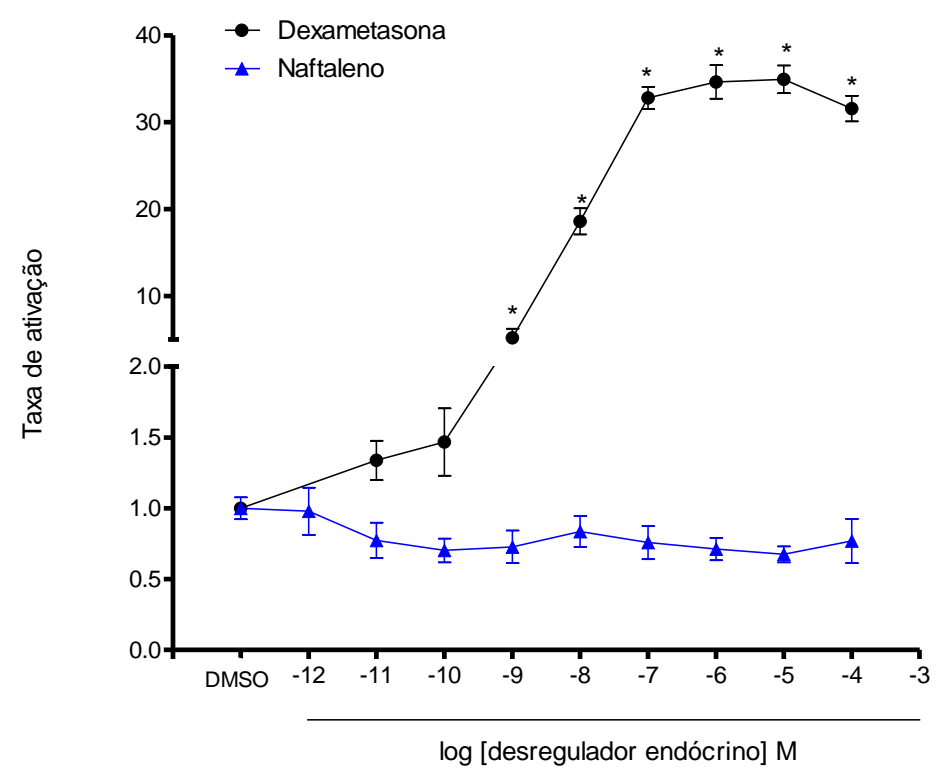

Figura 15 - O naftaleno não apresenta atividade agonista em GR $\alpha$. Células HeLa cotransfectadas com vetor de expressão do GR $\alpha$ humano e com o gene repórter luciferase dirigido pelo elemento responsivo ao (GRE-Luc) e tratadas com veículo (DMSO), dexametasona (controle positivo) ou naftaleno, durante $24 \mathrm{~h}$, e em seguida lisadas para determinação da atividade de luciferase. Dados expressos como média \pm EPM da taxa de ativação da transcrição em relação ao veículo DMSO, de 2 experimentos independentes realizados em triplicata. * Significativamente diferente do veículo pela análise de variância (ANOVA) seguida pelo teste de NewmanKeuls. 


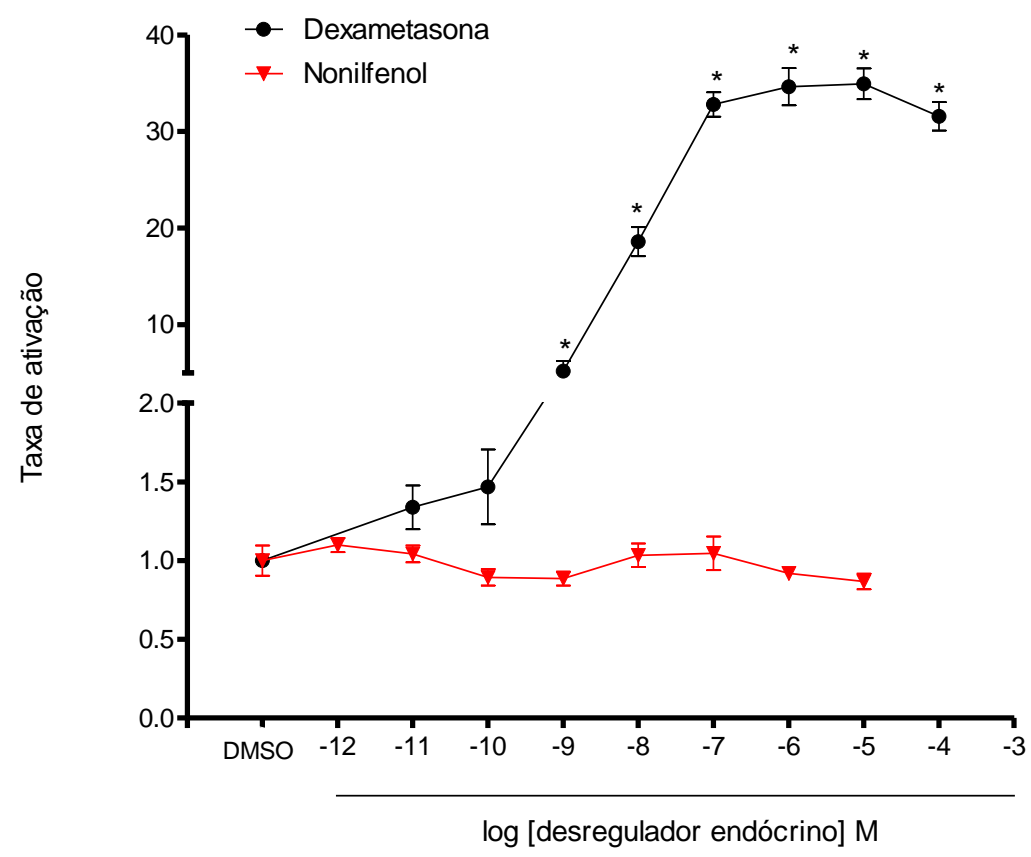

Figura 16 - O nonilfenol não apresenta atividade agonista em GR $\alpha$. Células HeLa cotransfectadas com vetor de expressão do GR $\alpha$ humano e com o gene repórter luciferase dirigido pelo elemento responsivo ao (GRE-Luc) e tratadas com veículo (DMSO), dexametasona (controle positivo) ou nonilfenol, durante 24h, e em seguida lisadas para determinação da atividade de luciferase. Dados expressos como média \pm EPM da taxa de ativação da transcrição em relação ao veículo DMSO, de 2 experimentos independentes realizados em triplicata. * Significativamente diferente do veículo pela análise de variância (ANOVA) seguida pelo teste de NewmanKeuls.

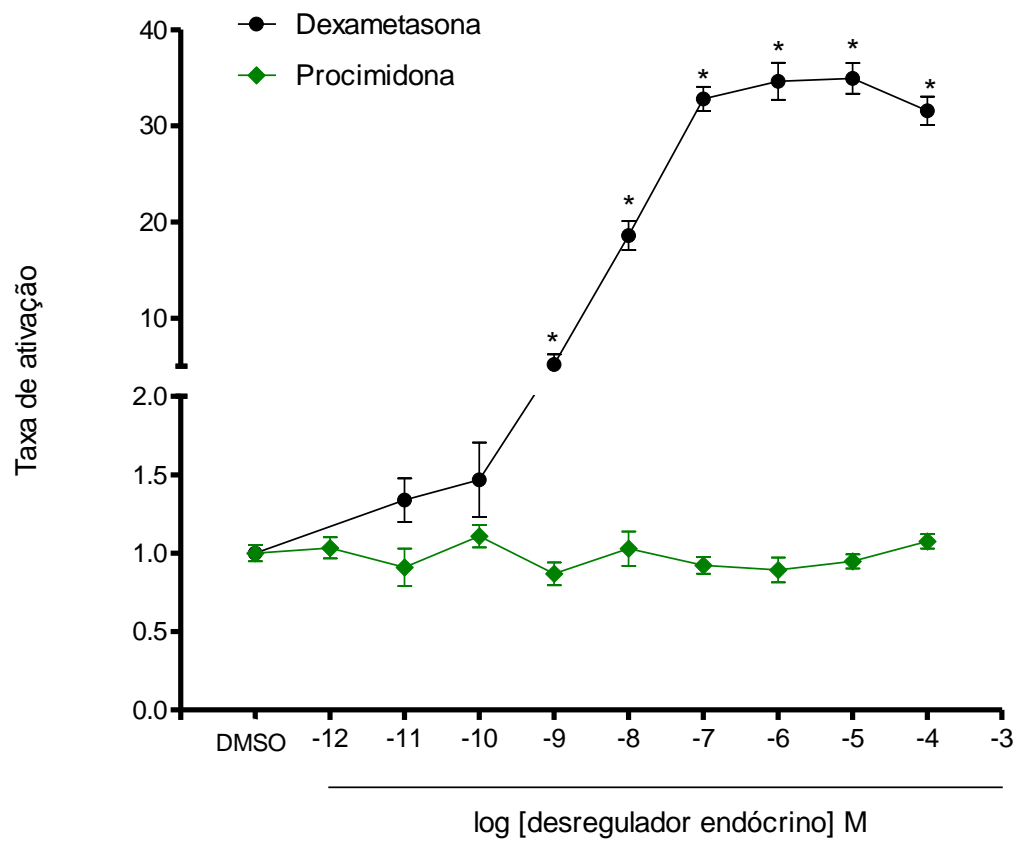

Figura 17 - A procimidona não apresenta atividade agonista em GRa. Células HeLa cotransfectadas com vetor de expressão do GR $\alpha$ humano e com o gene repórter luciferase dirigido pelo elemento responsivo ao (GRE-Luc) e tratadas com veículo (DMSO), dexametasona (controle positivo) ou procimidona, durante $24 \mathrm{~h}$, e em seguida lisadas para determinação da atividade de luciferase. Dados expressos como média \pm EPM da taxa de ativação da transcrição em relação ao veículo DMSO, de 2 experimentos independentes realizados em triplicata. * Significativamente diferente do veículo pela análise de variância (ANOVA) seguida pelo teste de NewmanKeuls. 


\subsection{EFEITOS DO FLUORENO, NAFTALENO, NONILFENOL E PROCIMIDONA SOBRE A ADIPOGÊNESE EM CULTURA DE CÉLULAS}

A atividade dos DE estudados foi avaliada também em um contexto fisiológico, representado pela diferenciação, em cultura, de pré-adipócitos ou células mesenquimais em adipócitos. Foi realizado, inicialmente, rastreamento da adipogênese em cultura com a utilização de células mesenquimais murinas C3H10T1/2, induzidas a se diferenciar em adipócitos com a exposição à combinação IBMX, dexametasona e insulina, e avaliadas, ao final do período de diferenciação, quanto ao acúmulo lipídico intracelular pela coloração com óleo vermelho O. Estas células foram tratadas, durante todo o período de diferenciação, com as 9 concentrações de fluoreno, naftaleno, nonilfenol e procimidona que não comprometeram a viabilidade celular (Figura 8). Nas Figuras 18 a 21, são apresentados os resultados obtidos nas maiores concentrações de cada um dos 4 compostos. Foi observado apenas discreto acúmulo lipídico intracelular nas células tratadas com nonilfenol, sobretudo na concentração de $10^{-7} \mathrm{M}$ (Figura 20).

O mesmo experimento foi realizado na linhagem de pré-adipócitos 3T3-L1 (Figuras 22 a 25). Foi observado aumento do acúmulo lipídico intracelular em resposta às maiores concentrações testadas do nonilfenol (Figura 24), porém não em resposta ao fluoreno (Figura 22), naftaleno (Figura 23) ou procimidona (Figura 25). 


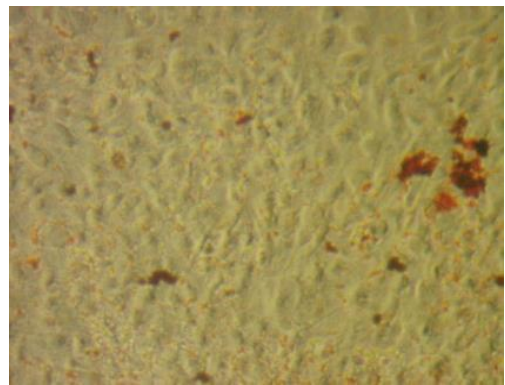

1. Não diferenciado

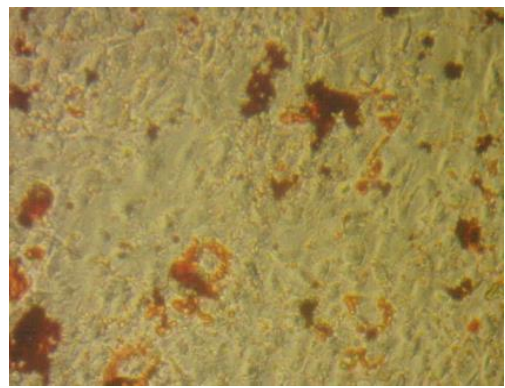

4. Fluoreno $10^{-7} \mathrm{M}$

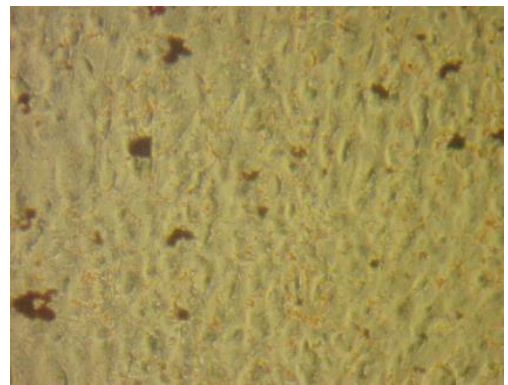

2. DMSO

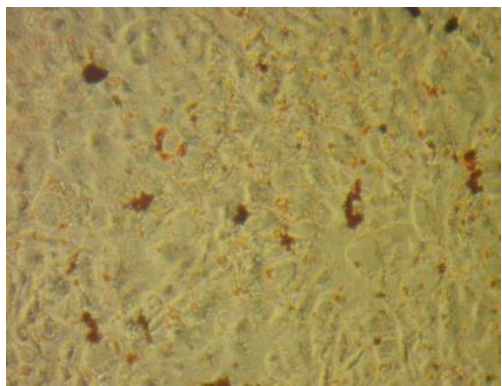

5. Fluoreno $10^{-6} \mathrm{M}$

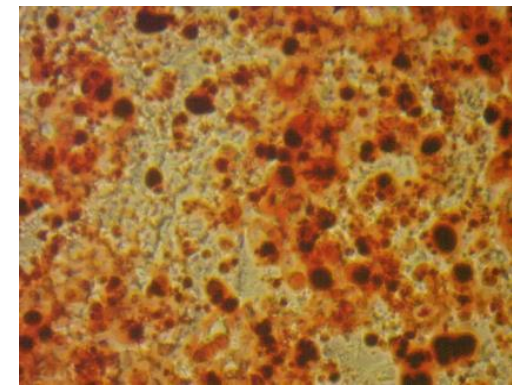

3. Rosiglitazona $10^{-6} \mathrm{M}$

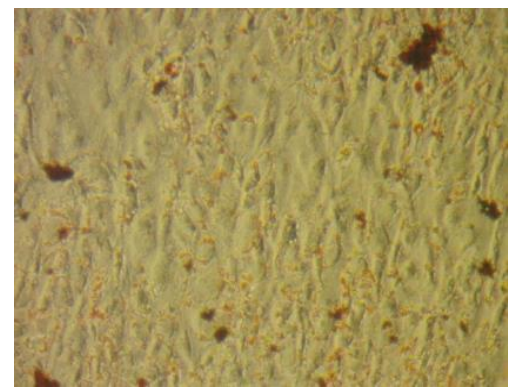

6. Fluoreno $10^{5} \mathrm{M}$

Figura 18 - Efeito do fluoreno sobre a adipogênese em células mesenquimais C3H10T1/2. Dois dias após a confluência, células $\mathrm{C} 3 \mathrm{H} 10 \mathrm{~T} 1 / 2$ foram induzidas a se diferenciar em adipócitos com $1 \mu \mathrm{M}$ de dexametasona, 0,5 $\mathrm{mM}$ de IBMX, e $1 \mu \mathrm{g} / \mathrm{mL}$ de insulina por quatro dias e, em seguida, mantidas em meio contendo $1 \mu \mathrm{g} / \mathrm{mL}$ de insulina. Durante o período de cultivo, foram tratadas com veículo (DMSO), rosiglitazona $(1 \mu \mathrm{M})$ ou concentrações crescentes de fluoreno. Após 10 dias, foram coradas com óleo vermelho $\mathrm{O}$ e observadas por microscopia (aumento de 20X).

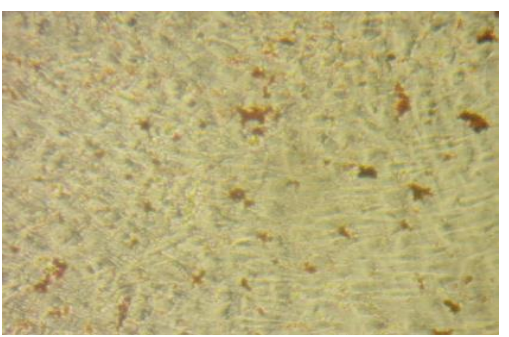

1. Não diferenciado

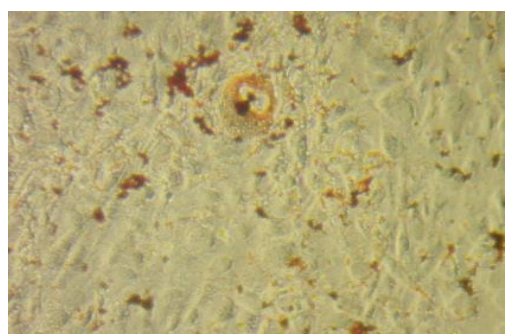

4. Naftaleno $10^{-7} \mathrm{M}$

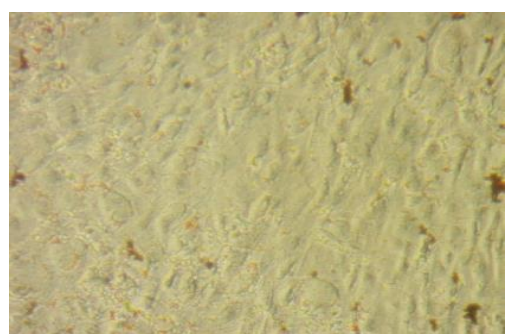

\section{DMSO}

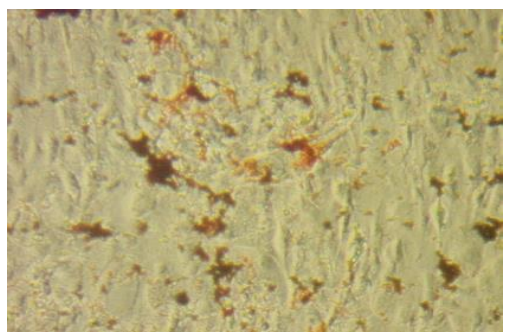

5. Naftaleno $10^{-6} \mathrm{M}$

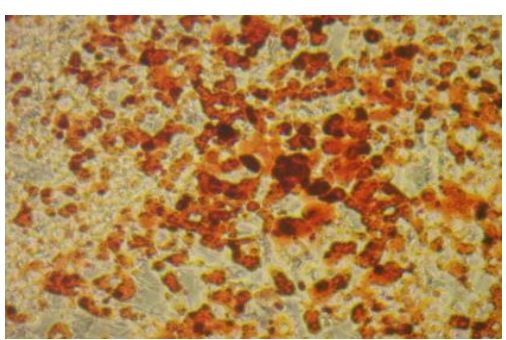

3. Rosiglitazona $10^{-6} \mathrm{M}$

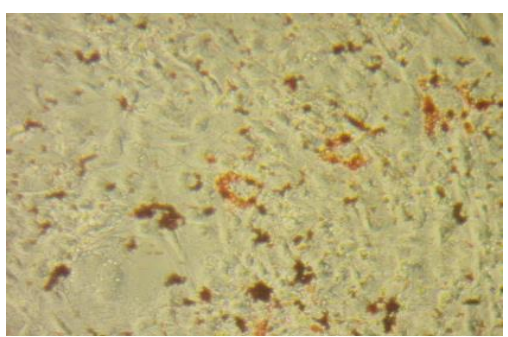

6. Naftaleno $10^{-5} \mathrm{M}$

Figura 19 - Efeito do naftaleno sobre a adipogênese em células mesenquimais C3H10T1/2. Dois dias após a confluência, células C3H10T1/2 foram induzidas a se diferenciar em adipócitos com $1 \mu \mathrm{M}$ de dexametasona, 0,5 $\mathrm{mM}$ de IBMX, e $1 \mu \mathrm{g} / \mathrm{mL}$ de insulina por quatro dias e, em seguida, mantidas em meio contendo $1 \mu \mathrm{g} / \mathrm{mL}$ de insulina. Durante o período de cultivo, foram tratadas com veículo (DMSO), rosiglitazona $(1 \mu \mathrm{M})$ ou concentrações crescentes de naftaleno. Após 10 dias, foram coradas com óleo vermelho $\mathrm{O}$ e observadas por microscopia (aumento de 20X). 


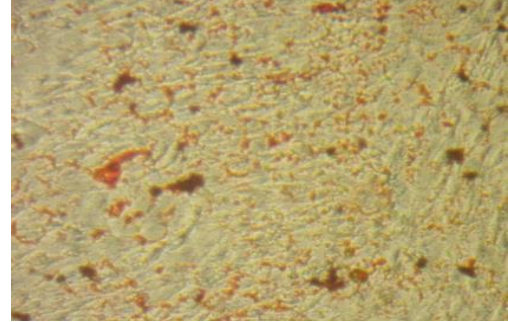

\section{Não diferenciado}

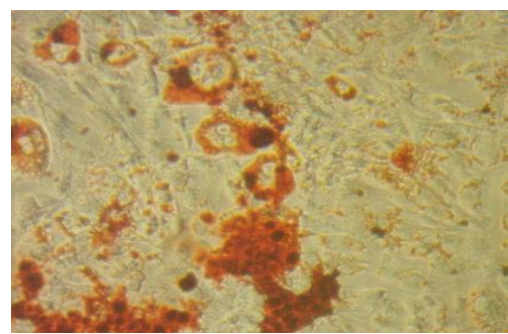

4. Nonilfenol $10^{-7} \mathrm{M}$

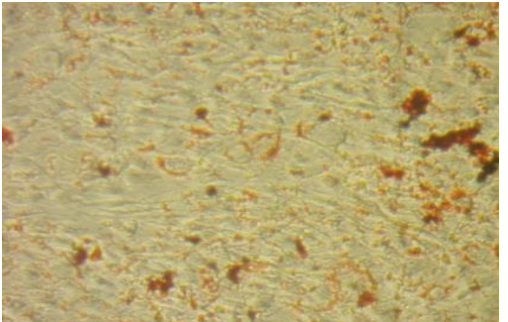

2. DMSO

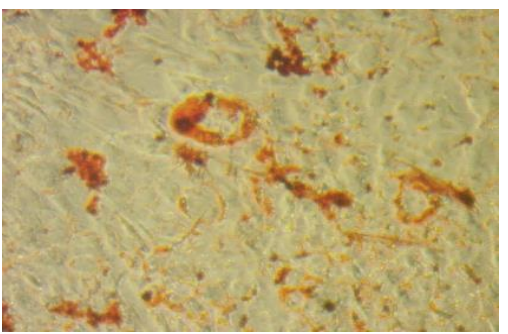

5. Nonilfenol $10^{-6} \mathrm{M}$

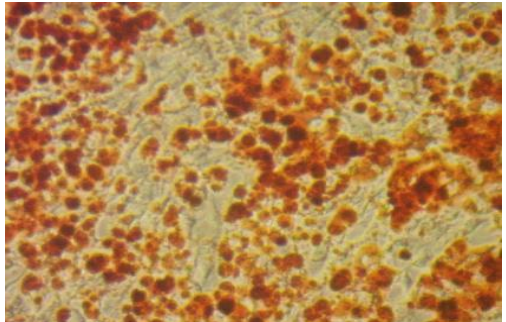

3. Rosiglitazona $10^{-6} \mathrm{M}$

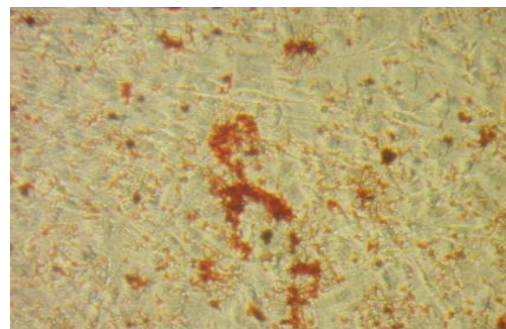

6. Nonilfenol $10^{-5} \mathrm{M}$

Figura 20 -. Efeito do nonilfenol sobre a adipogênese em células mesenquimais C3H10T1/2. Dois dias após a confluência, células C3H10T1/2 foram induzidas a se diferenciar em adipócitos com $1 \mu \mathrm{M}$ de dexametasona, 0,5 $\mathrm{mM}$ de IBMX, e $1 \mu \mathrm{g} / \mathrm{mL}$ de insulina por quatro dias e, em seguida, mantidas em meio contendo $1 \mu \mathrm{g} / \mathrm{mL}$ de insulina. Durante o período de cultivo, foram tratadas com veículo (DMSO), rosiglitazona (1 $\mu \mathrm{M})$ ou concentrações crescentes de nonilfenol. Após 10 dias, foram coradas com óleo vermelho $\mathrm{O}$ e observadas por microscopia (aumento de 20X).

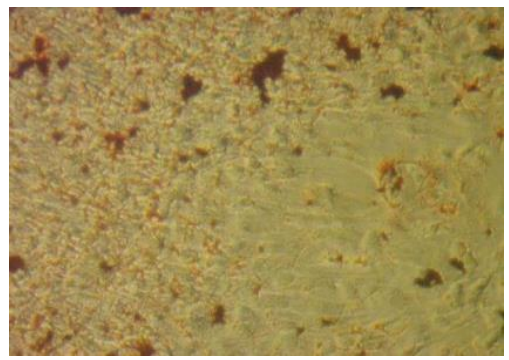

1. Não diferenciado

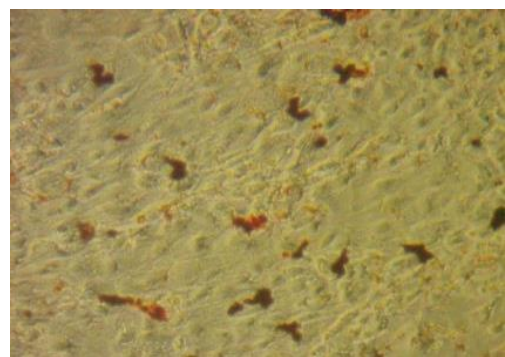

4. Procimidona $10^{-7} \mathrm{M}$

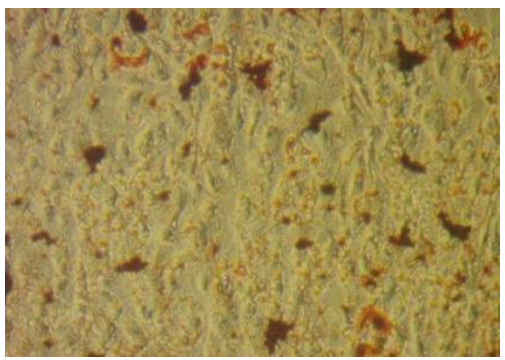

2. DMSO

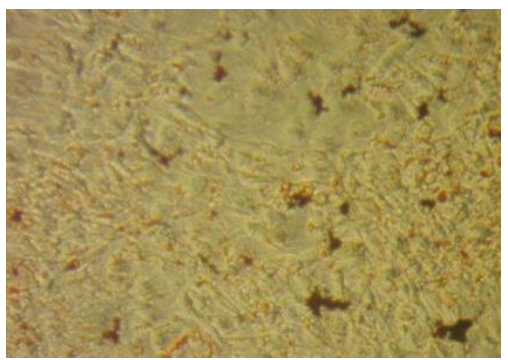

5. Procimidona $10^{-6} \mathrm{M}$

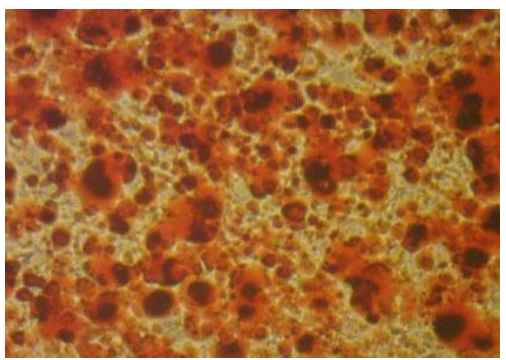

3. Rosiglitazona $10^{-6} \mathrm{M}$

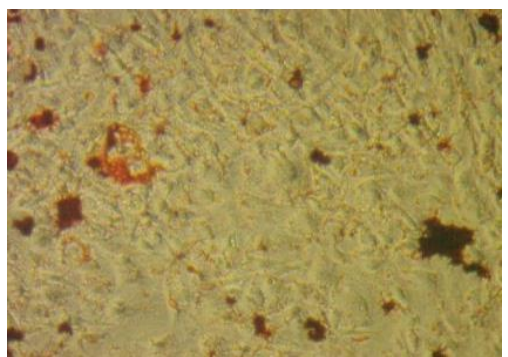

6. Procimidona $10^{-5} \mathrm{M}$

Figura 21 - Efeito da procimidona sobre a adipogênese em células mesenquimais C3H10T1/2. Dois dias após a confluência, células C3H10T1/2 foram induzidas a se diferenciar em adipócitos com $1 \mu \mathrm{M}$ de dexametasona, 0,5 $\mathrm{mM}$ de IBMX, e $1 \mu \mathrm{g} / \mathrm{mL}$ de insulina por quatro dias e, em seguida, mantidas em meio contendo $1 \mu \mathrm{g} / \mathrm{mL} \mathrm{de}$ insulina. Durante o período de cultivo, foram tratadas com veículo (DMSO), rosiglitazona (1 $\mu \mathrm{M})$ ou concentrações crescentes de procimidona. Após 10 dias, foram coradas com óleo vermelho $\mathrm{O}$ e observadas por microscopia (aumento de 20X). 

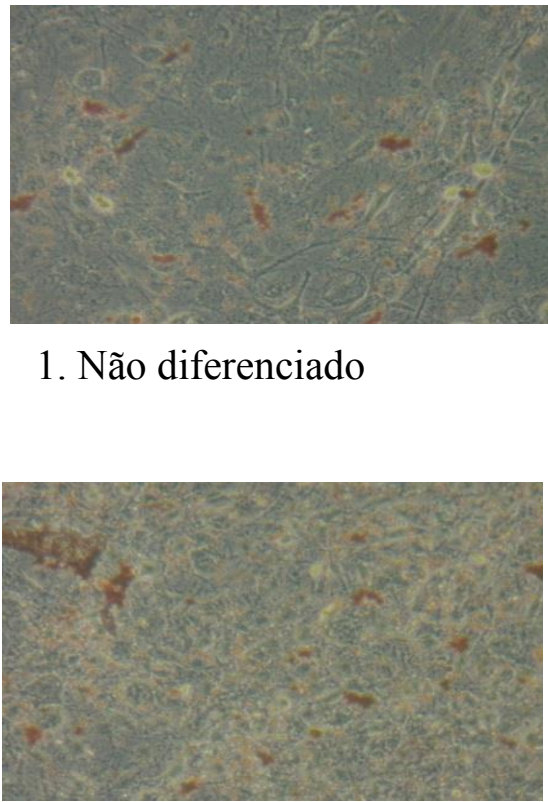

5. Fluoreno $10^{-10} \mathrm{M}$

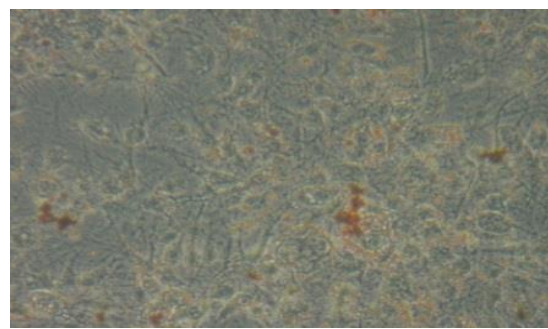

9. Fluoreno $10^{-6} \mathrm{M}$
1. Não diferenciado

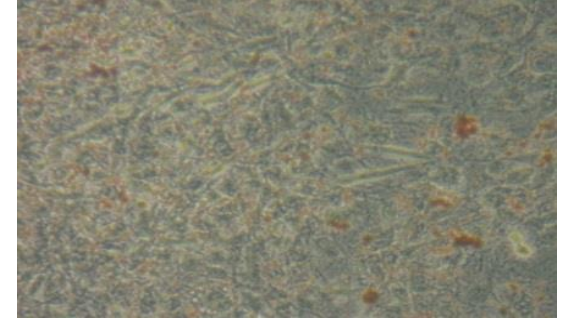

2. DMSO

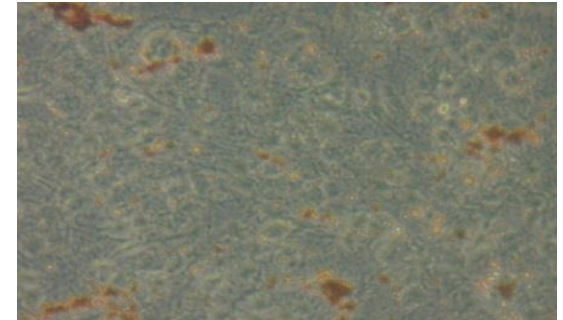

6. Fluoreno $10^{-9} \mathrm{M}$

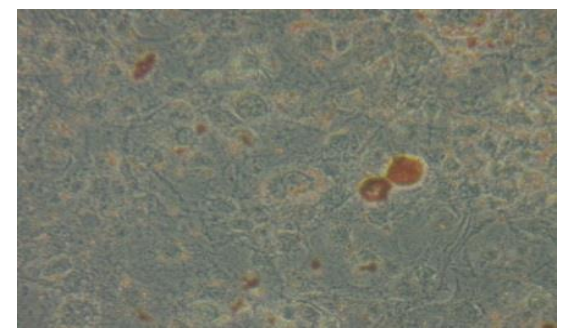

10. Fluoreno $10^{-5} \mathrm{M}$

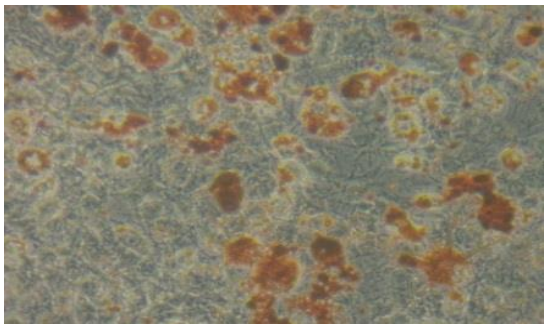

3. Rosiglitazona $10^{-6} \mathrm{M}$

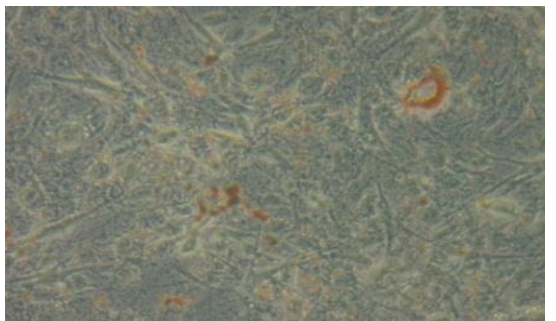

7. Fluoreno $10^{-8} \mathrm{M}$

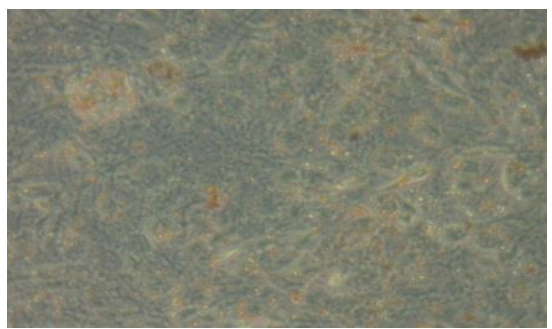

11.Fluoreno $10^{-4} \mathrm{M}$

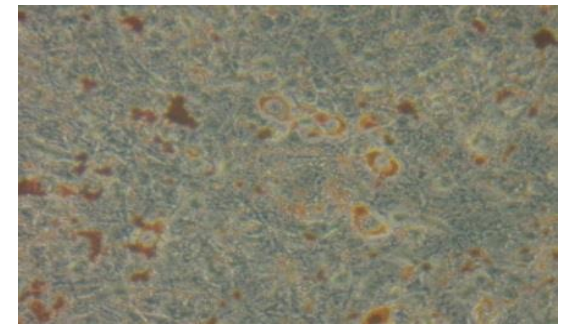

4. Fluoreno $10^{-11} \mathrm{M}$

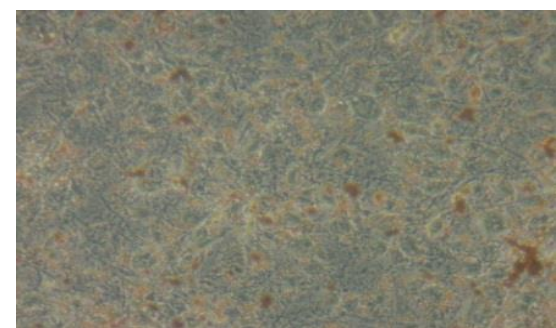

8. Fluoreno $10^{-7} \mathrm{M}$

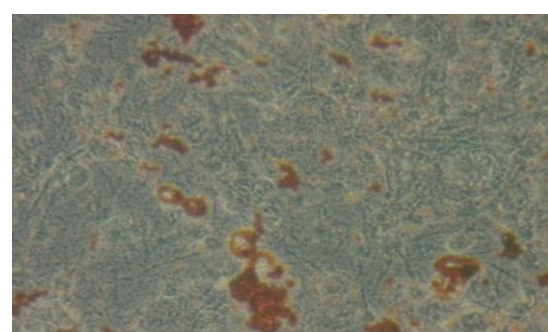

12. Fluoreno $10^{-3} \mathrm{M}$

Figura 22 - Efeito do fluoreno sobre a adipogênese em pré-adipócitos 3T3-L1 induzidos a se diferenciar em adipócitos com meio completo. Dois dias após a confluência, células 3T3-L1 foram induzidas a se diferenciar em adipócitos com $1 \mu \mathrm{M}$ de dexametasona, 0,5 mM de IBMX, e $1 \mu \mathrm{g} / \mathrm{mL}$ de insulina por quatro dias e, em seguida, mantidas em meio contendo $1 \mu \mathrm{g} / \mathrm{mL}$ de insulina. Durante o período de cultivo, foram tratadas com veículo (DMSO), rosiglitazona (1 $\mu \mathrm{M})$ ou concentrações crescentes de fluoreno. Após 10 dias, foram coradas com óleo vermelho $\mathrm{O}$ e observadas por microscopia (aumento de 20X). 


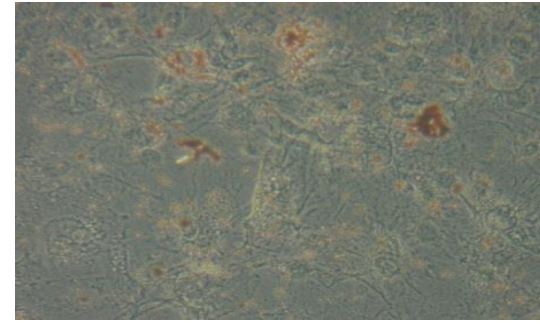

1.Não diferenciado

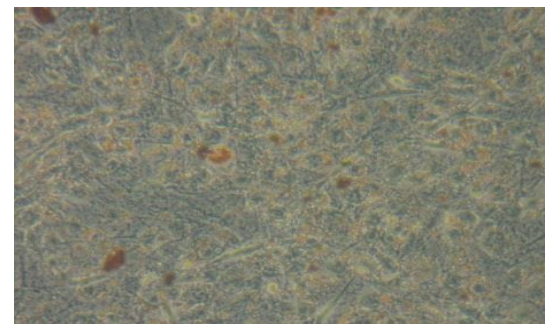

5. Naftaleno $10^{-10} \mathrm{M}$

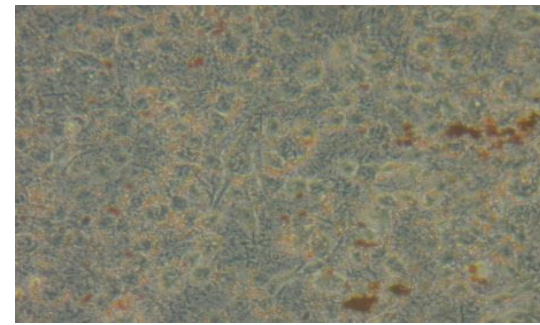

9. Naftaleno $10^{-6} \mathrm{M}$

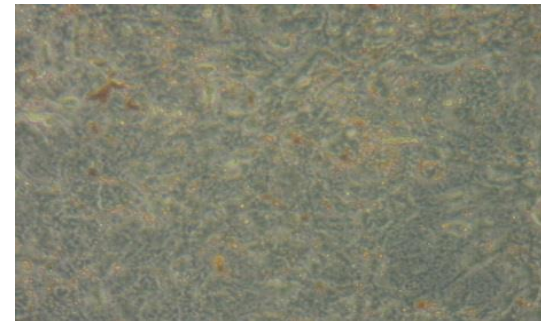

2. DMSO

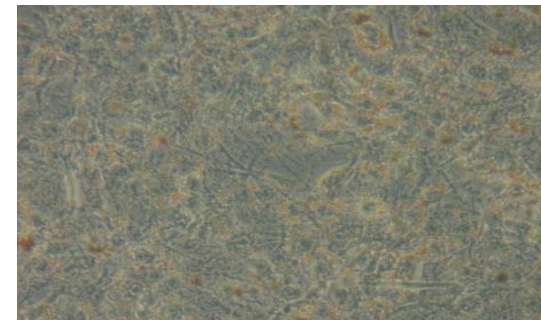

6. Naftaleno $10^{-9} \mathrm{M}$

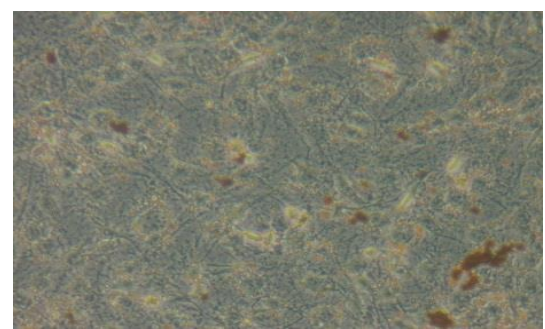

10. Naftaleno $10^{-5} \mathrm{M}$

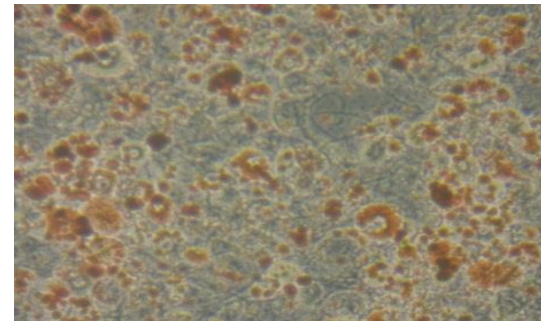

3. Rosiglitazona $10^{-6} \mathrm{M}$

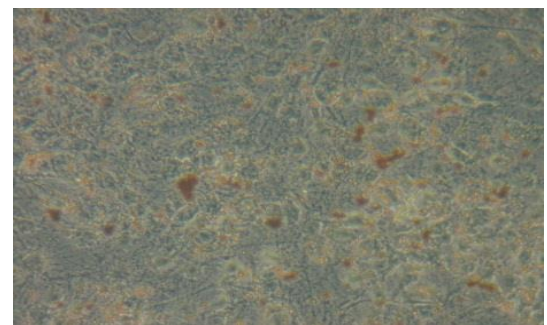

7. Naftaleno $10^{-8} \mathrm{M}$

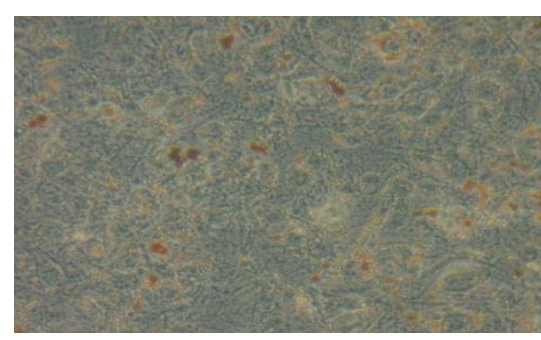

11. Naftaleno $10^{-4} \mathrm{M}$

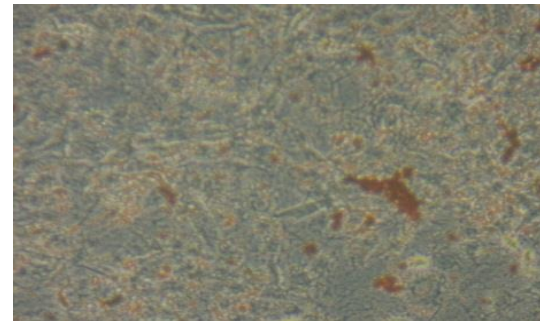

4. Naftaleno $10^{-11} \mathrm{M}$

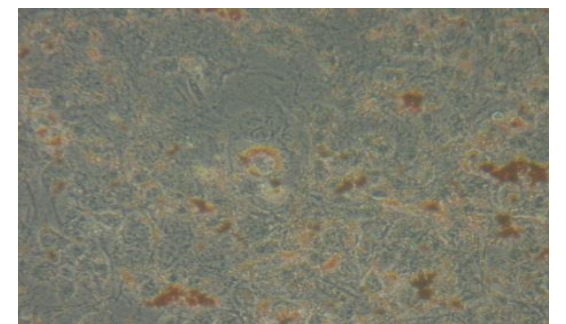

8. Naftaleno $10^{-7} \mathrm{M}$

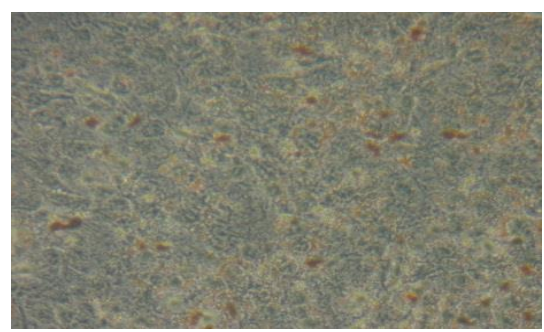

12. Naftaleno $10^{-3} \mathrm{M}$

Figura 23 - Efeito do naftaleno sobre a adipogênese em pré-adipócitos 3T3-L1 induzidos a se diferenciar em adipócitos com meio completo. Dois dias após a confluência, células 3T3-L1 foram induzidas a se diferenciar em adipócitos com $1 \mu \mathrm{M}$ de dexametasona, 0,5 mM de IBMX, e $1 \mu \mathrm{g} / \mathrm{mL}$ de insulina por quatro dias e, em seguida, mantidas em meio contendo $1 \mu \mathrm{g} / \mathrm{mL}$ de insulina. Durante o período de cultivo, foram tratadas com veículo (DMSO), rosiglitazona (1 $\mu \mathrm{M})$ ou concentrações crescentes de naftaleno. Após 10 dias, foram coradas com óleo vermelho $\mathrm{O}$ e observadas por microscopia (aumento de 20X). 


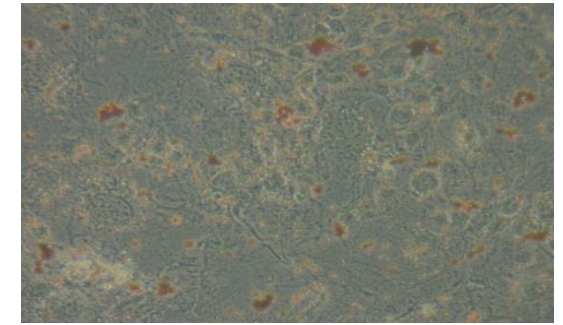

1. Não diferenciado

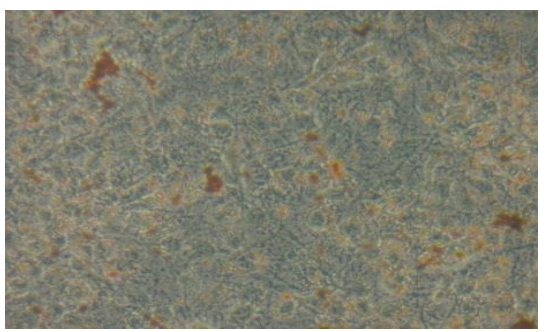

5. Nonilfenol $10^{-11} \mathrm{M}$

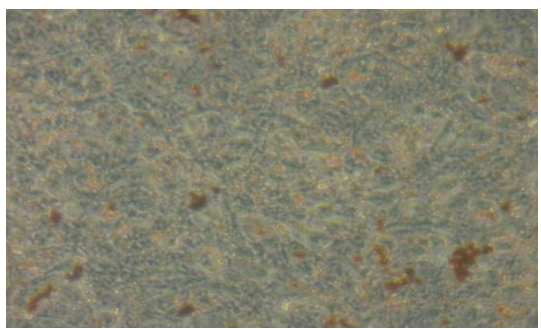

9. Nonilfenol $10^{-7} \mathrm{M}$

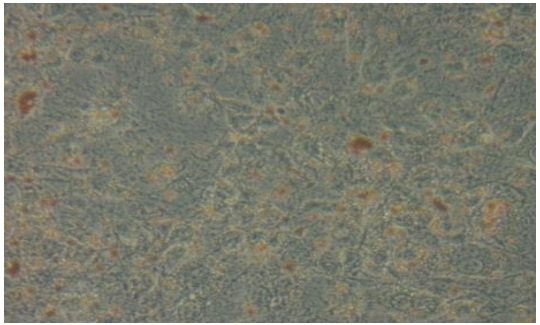

2. DMSO

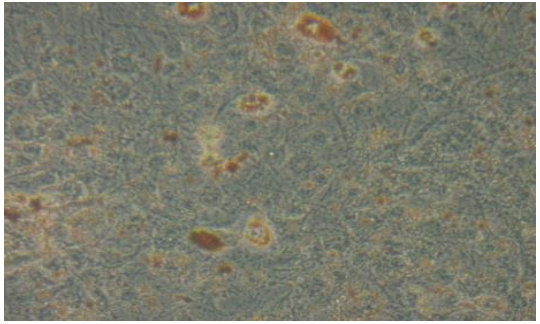

6. Nonilfenol $10^{-10} \mathrm{M}$

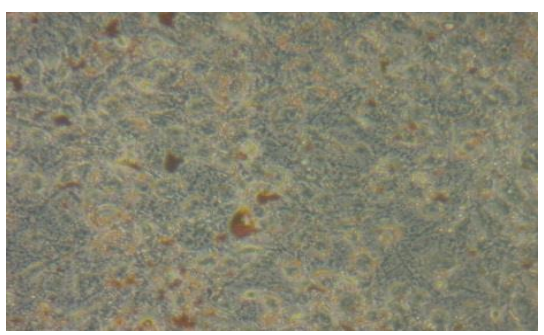

10. Nonilfenol $10^{-6} \mathrm{M}$

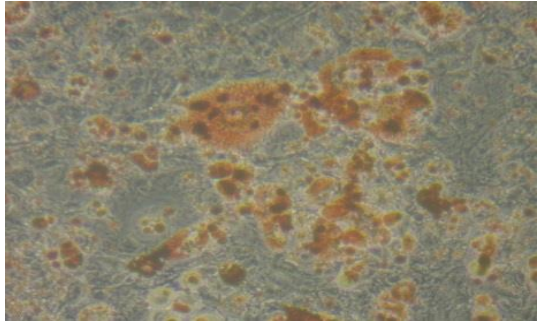

3. Rosiglitazona $10^{-6} \mathrm{M}$

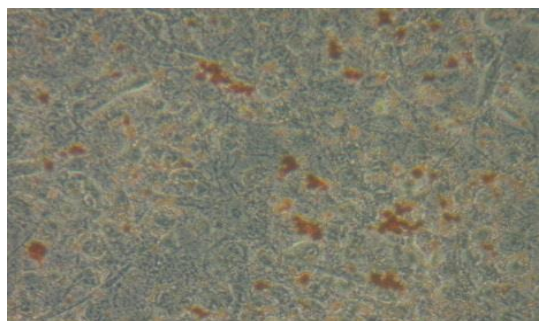

7. Nonilfenol $10^{-9} \mathrm{M}$

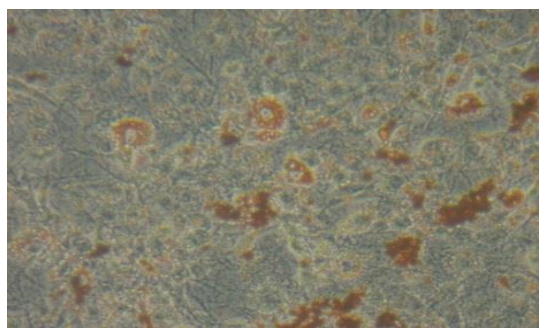

11. Nonilfenol $10^{-5} \mathrm{M}$

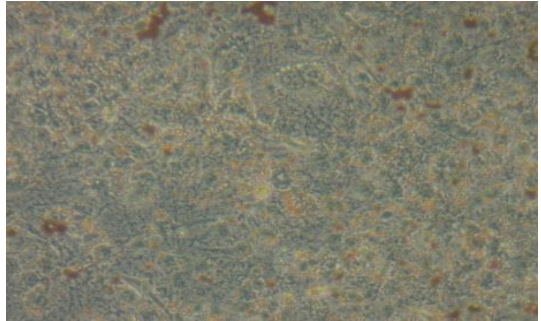

4. Nonilfenol $10^{-11} \mathrm{M}$

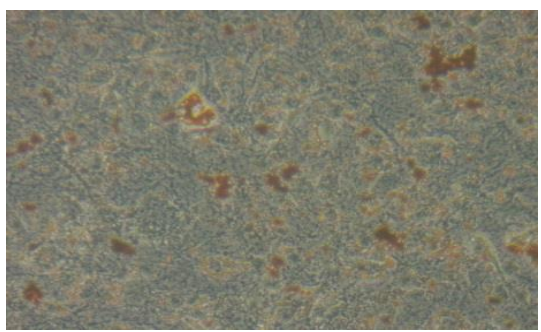

8. Nonilfenol $10^{-8} \mathrm{M}$

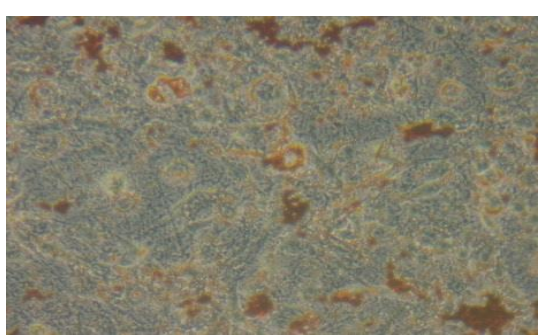

12. Nonilfenol $10^{-4} \mathrm{M}$

Figura 24 - Efeito do nonilfenol sobre a adipogênese em pré-adipócitos 3T3-L1 induzidos a se diferenciar em adipócitos com meio completo. Dois dias após a confluência, células 3T3-L1 foram induzidas a se diferenciar em adipócitos com $1 \mu \mathrm{M}$ de dexametasona, 0,5 mM de IBMX, e $1 \mu \mathrm{g} / \mathrm{mL}$ de insulina por quatro dias e, em seguida, mantidas em meio contendo $1 \mu \mathrm{g} / \mathrm{mL}$ de insulina. Durante o período de cultivo, foram tratadas com veículo (DMSO), rosiglitazona (1 $\mu \mathrm{M})$ ou concentrações crescentes de nonilfenol. Após 10 dias, foram coradas com óleo vermelho $\mathrm{O}$ e observadas por microscopia (aumento de 20X). 


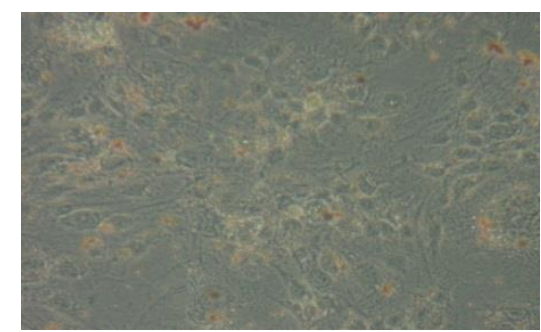

1. Não diferenciado

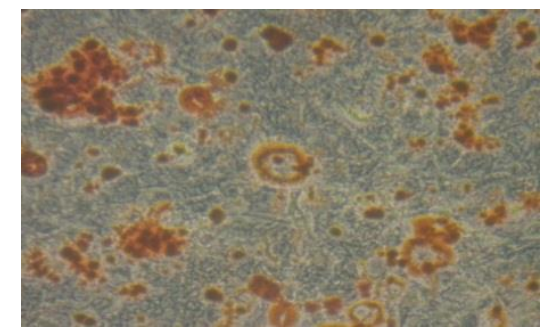

5. Procimidona $10^{-10} \mathrm{M}$

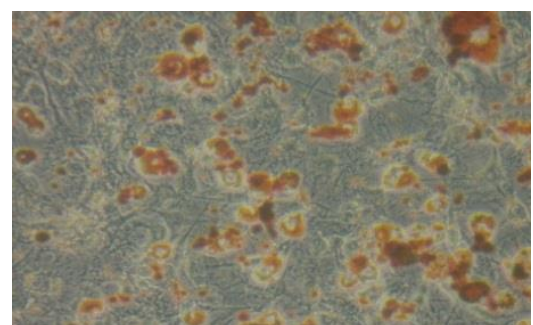

9. Procimidona $10^{-6} \mathrm{M}$

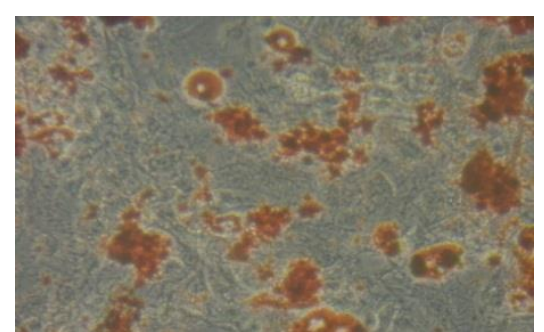

2. DMSO

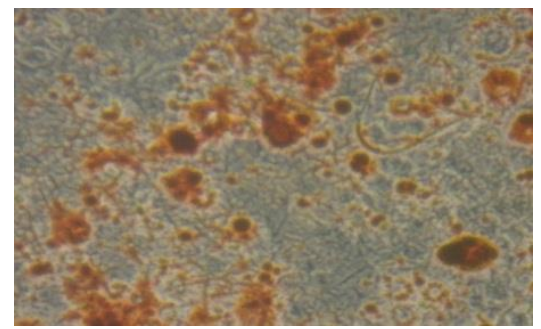

6. Procimidona $10^{-9} \mathrm{M}$

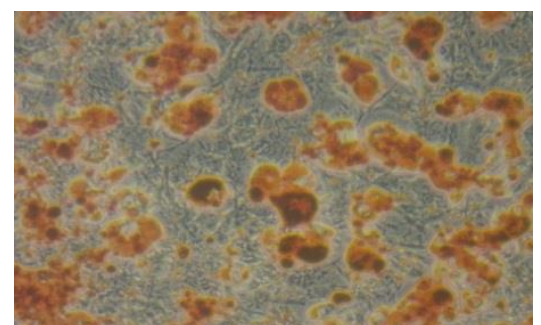

10. Procimidona $10^{-5} \mathrm{M}$

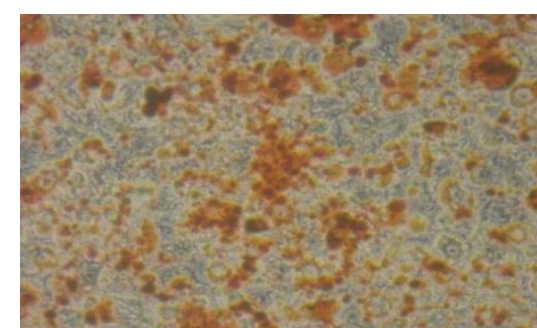

3. Rosiglitazona ${ }^{10-6} \mathrm{M}$

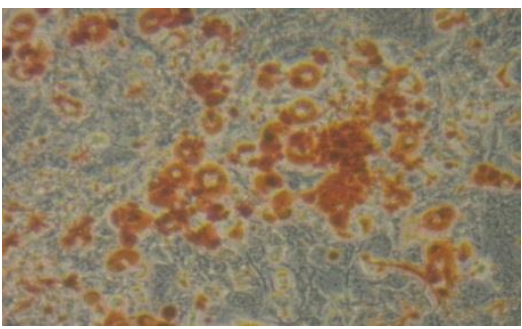

7. Procimidona $10^{-8} \mathrm{M}$

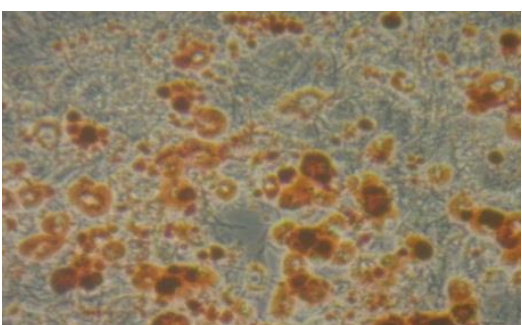

11. Procimidona $10^{-4} \mathrm{M}$

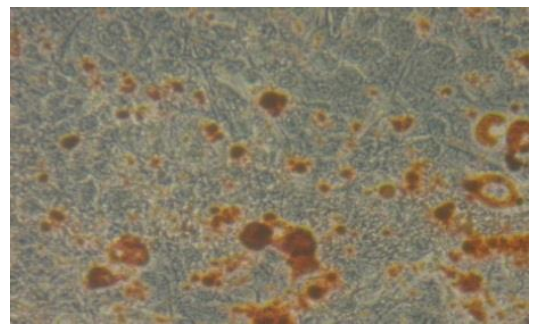

4. Procimidona $10^{-11} \mathrm{M}$

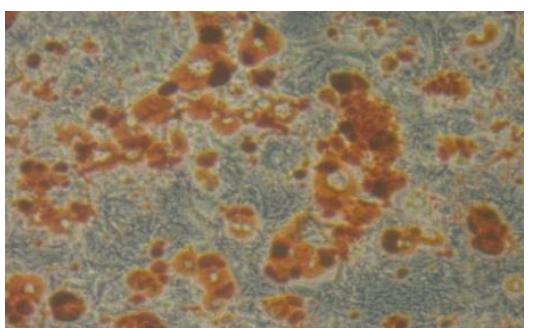

8. Procimidona $10^{-7} \mathrm{M}$

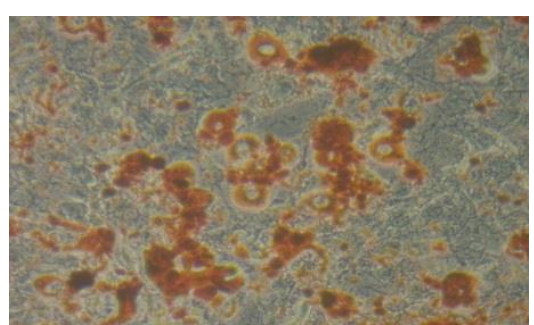

12. Procimidona $10^{-3} \mathrm{M}$

Figura 25 - Efeito da procimidona sobre a adipogênese em pré-adipócitos 3T3-L1 induzidos a se diferenciar em adipócitos com meio completo. Dois dias após a confluência, células 3T3-L1 foram induzidas a se diferenciar em adipócitos com $1 \mu \mathrm{M}$ de dexametasona, $0,5 \mathrm{mM}$ de IBMX, e $1 \mu \mathrm{g} / \mathrm{mL}$ de insulina por quatro dias e, em seguida, mantidas em meio contendo $1 \mu \mathrm{g} / \mathrm{mL}$ de insulina. Durante o período de cultivo, foram tratadas com veículo (DMSO), rosiglitazona (1 $\mu$ M) ou concentrações crescentes de procimidona. Após 10 dias, foram coradas com óleo vermelho O e observadas por microscopia (aumento de 20X). 
A mistura IBMX, dexametasona e insulina representa um potente estímulo para a indução da adipogênese em cultura (NTAMBI; YOUNG-CHEUL, 2000). Desta forma, compostos com atividade adipogênica fraca podem não ter seu efeito facilmente observado. Considerando-se que o fluoreno, naftaleno e nonilfenol não apresentaram atividade adipogênica, evidenciada pelo acúmulo intracelular de lipídeos, em pré-adipócitos 3T3-L1 ou células mesenquimais C3H10T1/2 induzidos a se diferenciar com IBMX, dexametasona e insulina, pré-adipócitos 3T3-L1 foram induzidos a diferenciar-se em adipócitos de forma menos potente, com a utilização apenas de insulina a $10 \mu \mathrm{g} / \mathrm{mL}$, e mantidos em meio contendo insulina a $5 \mu \mathrm{g} / \mathrm{mL}$. Para estes experimentos, foram utilizadas as 3 maiores concentrações testadas de fluoreno e procimidona, as 3 maiores concentrações anteriores à maior concentração de naftaleno testadas (com a maior concentração foram observados precipitados no meio de cultura), e as 3 concentrações em que o nonilfenol induziu maior acúmulo intracelular de lipídeos nos ensaios anteriores, de $10^{-7} \mathrm{M}, 10^{-6} \mathrm{M}$ e $10^{-5} \mathrm{M}$ (Figuras 26 e 29).

Observou-se discreto aumento do acúmulo intracelular de lipídeos em pré-adipócitos 3T3-L1 tratados com fluoreno (Figura 26) e naftaleno (Figura 27), ambos na concentração de $10^{-7} \mathrm{M}$, em relação às células tratadas com veículo. Os pré-adipócitos tratados com nonilfenol também apresentaram aumento do acúmulo intracelular de lipídeos, nas 3 concentrações testadas, em relação ao grupo tratado com veículo (Figura 28), e comparável ao das células tratadas com rosiglitazona (Figura 28). Nas células tratadas com procimidona, observou-se também discreto acúmulo lipídico intracelular nas concentrações de $10^{-7} \mathrm{M}$ e $10^{-5} \mathrm{M}$, porém não na concentração de $10^{-6} \mathrm{M}$ (Figura 29). 


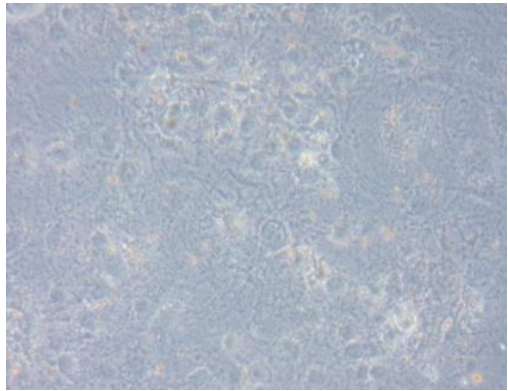

1. Não diferenciado

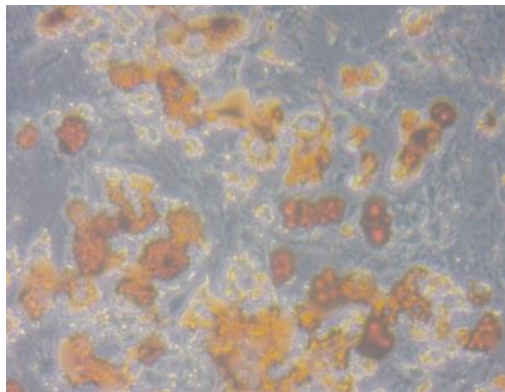

\section{Fluoreno $10^{-7} \mathrm{M}$}

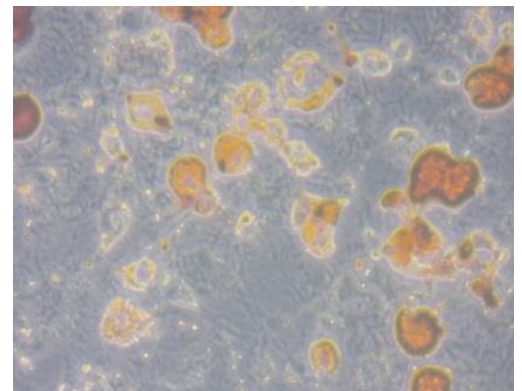

2. DMSO

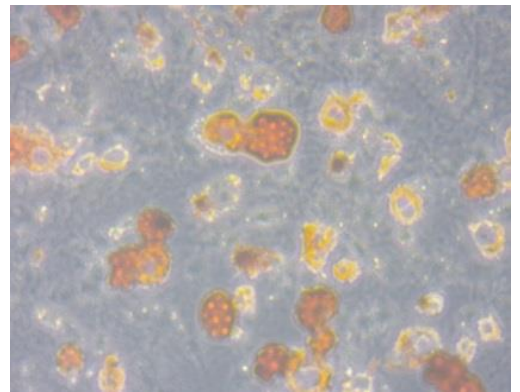

5. Fluoreno $10^{-6} \mathrm{M}$

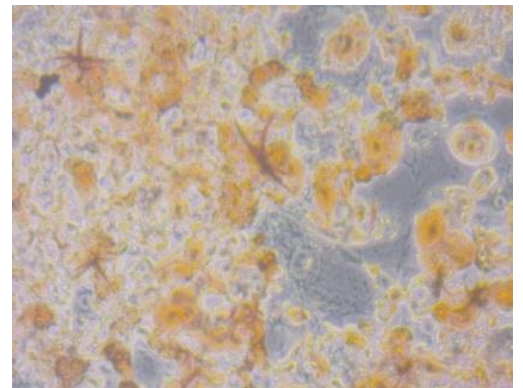

3.Rosiglitazona $10^{-6} \mathrm{M}$

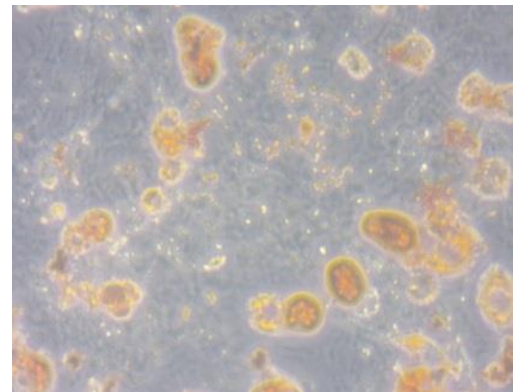

6. Fluoreno $10^{-5} \mathrm{M}$

Figura 26 - Efeito do fluoreno sobre a adipogênese em pré-adipócitos 3T3-L1 induzidos a se diferenciar com meio incompleto. Dois dias após a confluência, as células foram induzidas a se diferenciar em adipócitos com 10 $\mu \mathrm{g} / \mathrm{mL}$ de insulina por quatro dias e, em seguida, mantidas em meio contendo $5 \mu \mathrm{g} / \mathrm{mL}$ de insulina. Durante o período de cultivo, foram tratadas com veículo (DMSO), rosiglitazona $(1 \mu \mathrm{M})$ ou fluoreno nas concentrações indicadas. Após 10 dias, foram coradas com óleo vermelho O e observadas por microscopia (aumento de 20X).

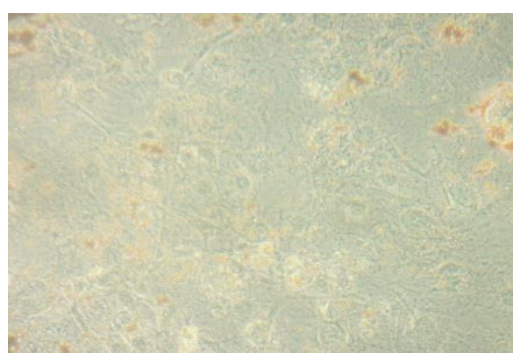

1. Não Diferenciado

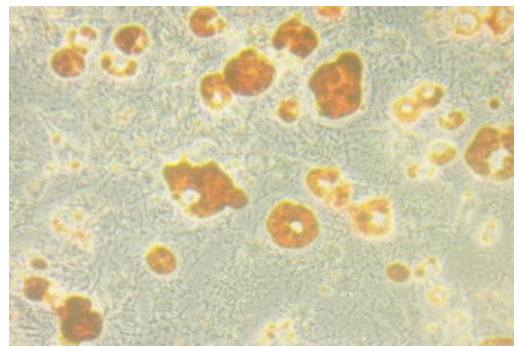

4. Naftaleno $10^{-7} \mathrm{M}$

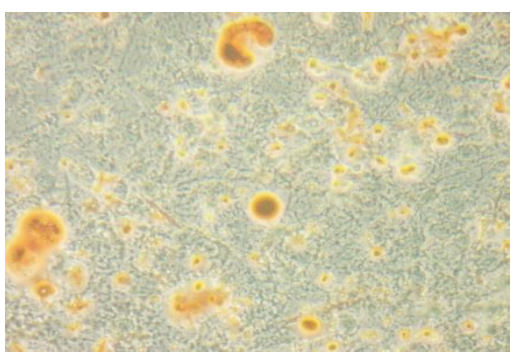

2. DMSO

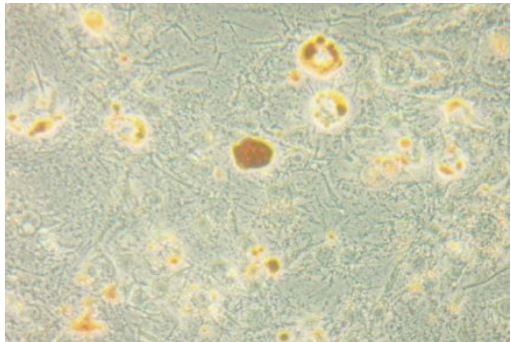

5. Naftaleno $10^{-6} \mathrm{M}$

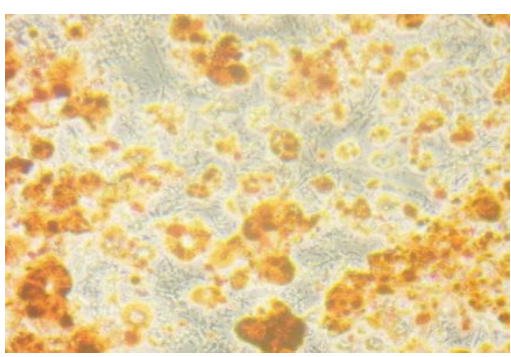

3. Rosiglitazona $10^{-6} \mathrm{M}$

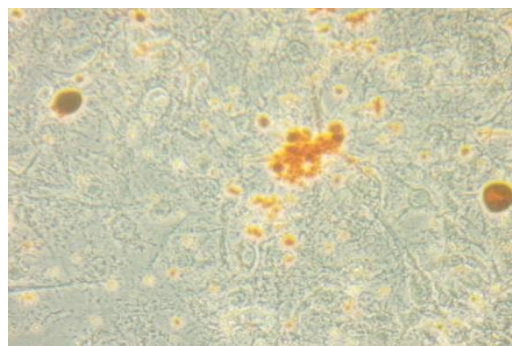

6. Naftaleno $10^{-5} \mathrm{M}$

Figura 27. Efeito do naftaleno sobre a adipogênese em pré-adipócitos 3T3-L1 induzidos a se diferenciar com meio incompleto. Dois dias após a confluência, as células foram induzidas a se diferenciar em adipócitos com 10 $\mu \mathrm{g} / \mathrm{mL}$ de insulina por quatro dias e, em seguida, mantidas em meio contendo $5 \mu \mathrm{g} / \mathrm{mL}$ de insulina. Durante o período de cultivo, foram tratadas com veículo (DMSO), rosiglitazona $(1 \mu \mathrm{M})$ ou naftaleno nas concentrações indicadas. Após 10 dias, foram coradas com óleo vermelho O e observadas por microscopia (aumento de 20X). 


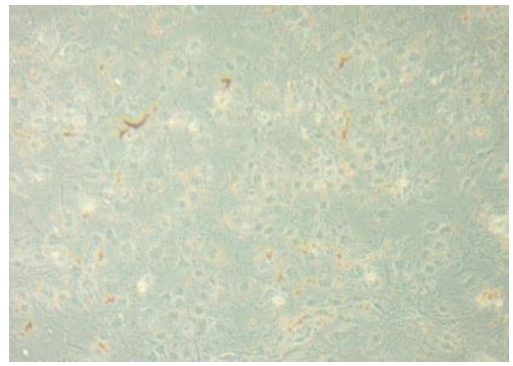

1. Não diferenciado

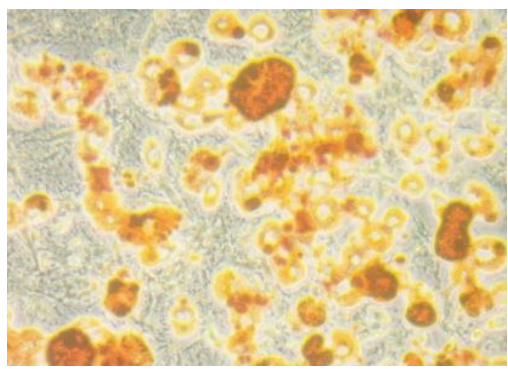

4. Nonilfenol $10^{-7} \mathrm{M}$

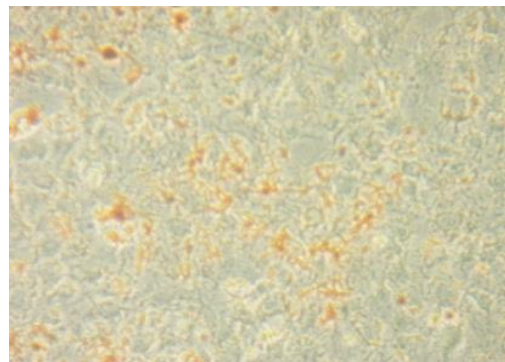

2. DMSO

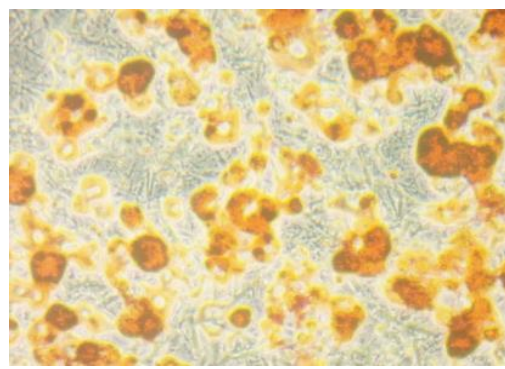

5. Nonilfenol $10^{-6} \mathrm{M}$

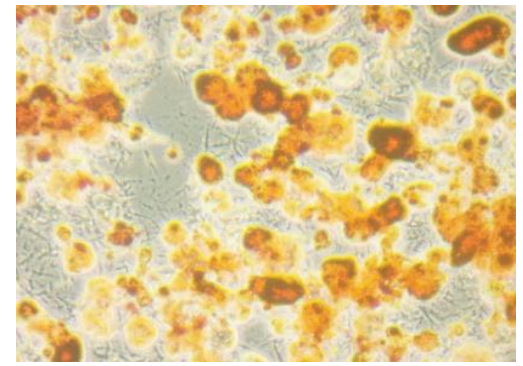

3. Rosiglitazona $10^{-6} \mathrm{M}$

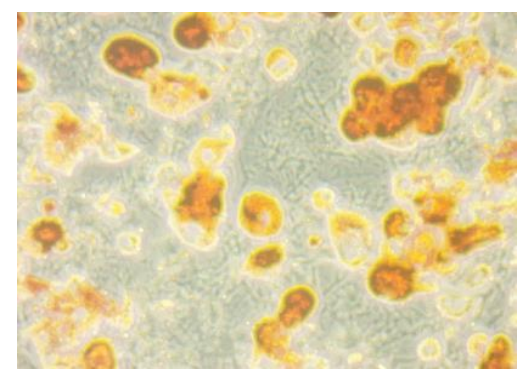

6. Nonilfenol $10^{-5} \mathrm{M}$

Figura 28 - Efeito do nonilfenol sobre a adipogênese em pré-adipócitos 3T3-L1 induzidos a se diferenciar com meio incompleto. Dois dias após a confluência, as células foram induzidas a se diferenciar em adipócitos com 10 $\mu \mathrm{g} / \mathrm{mL}$ de insulina por quatro dias e, em seguida, mantidas em meio contendo $5 \mu \mathrm{g} / \mathrm{mL}$ de insulina. Durante o período de cultivo, foram tratadas com veículo (DMSO), rosiglitazona $(1 \mu \mathrm{M})$ ou nonilfenol nas concentrações indicadas. Após 10 dias, foram coradas com óleo vermelho O e observadas por microscopia (aumento de 20X).

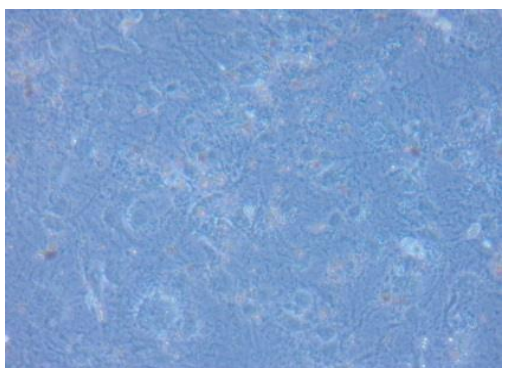

1. Não diferenciado

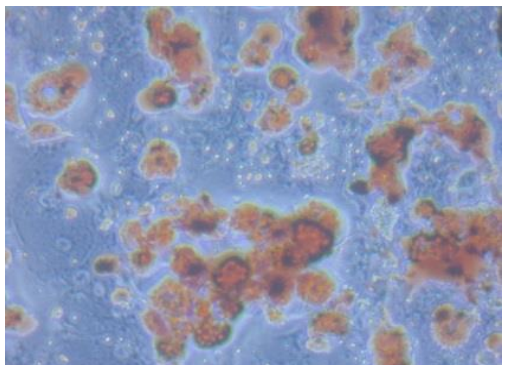

4. Procimidona $10^{-7} \mathrm{M}$

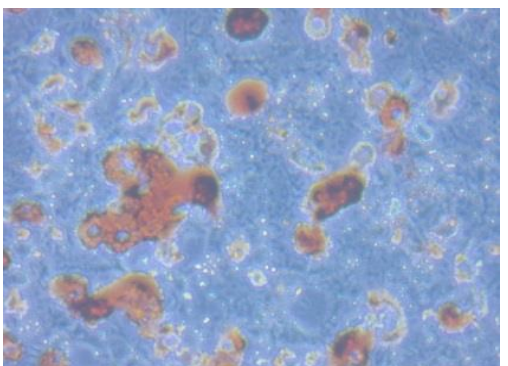

2. DMSO

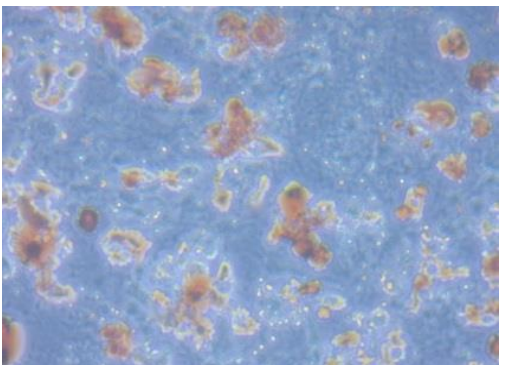

5. Procimidona $10^{-6} \mathrm{M}$

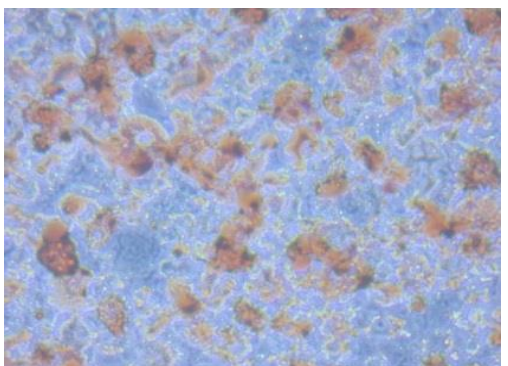

3. Rosiglitazona $10^{-6} \mathrm{M}$

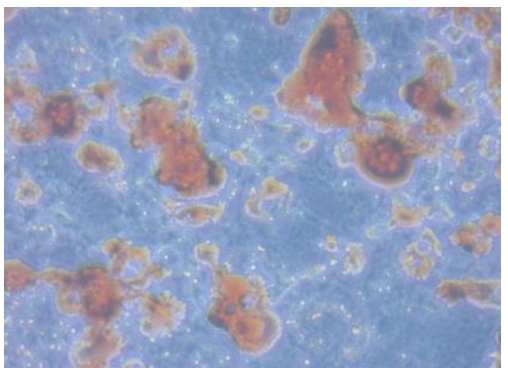

6. Procimidona $10^{-5} \mathrm{M}$

Figura 29 - Efeito da procimidona sobre a adipogênese em pré-adipócitos 3T3-L1 induzidos a se diferenciar com meio incompleto. Dois dias após a confluência, as células foram induzidas a se diferenciar em adipócitos com 10 $\mu \mathrm{g} / \mathrm{mL}$ de insulina por quatro dias e, em seguida, mantidas em meio contendo $5 \mu \mathrm{g} / \mathrm{mL}$ de insulina. Durante o período de cultivo, foram tratadas com veículo (DMSO), rosiglitazona $(1 \mu \mathrm{M})$ ou procimidona nas concentrações indicadas. Após 10 dias, foram coradas com óleo vermelho O e observadas por microscopia (aumento de 20X). 
A adipogênese em cultura foi avaliada também pela determinação de um marcador do adipócito maduro, a expressão do RNAm do gene que codifica a proteína ligadora de ácidos graxos adipocitária (Fabpa). Nas células mesenquimais C3H10T1/2 induzidas a se diferenciar em adipócitos na presença de rosiglitazona ou dos $4 \mathrm{DE}$ estudados, foi observado aumento significativo da expressão de Fabpa no grupo tratado com rosiglitazona, porém não em resposta ao tratamento com fluoreno, naftaleno, nonilfenol ou procimidona (Figura 30). Observou-se, contudo, tendência não significativa de aumento da expressão de Fabpa nas células induzidas a se diferenciar na presença do nonilfenol a $10^{-7} \mathrm{M}$.

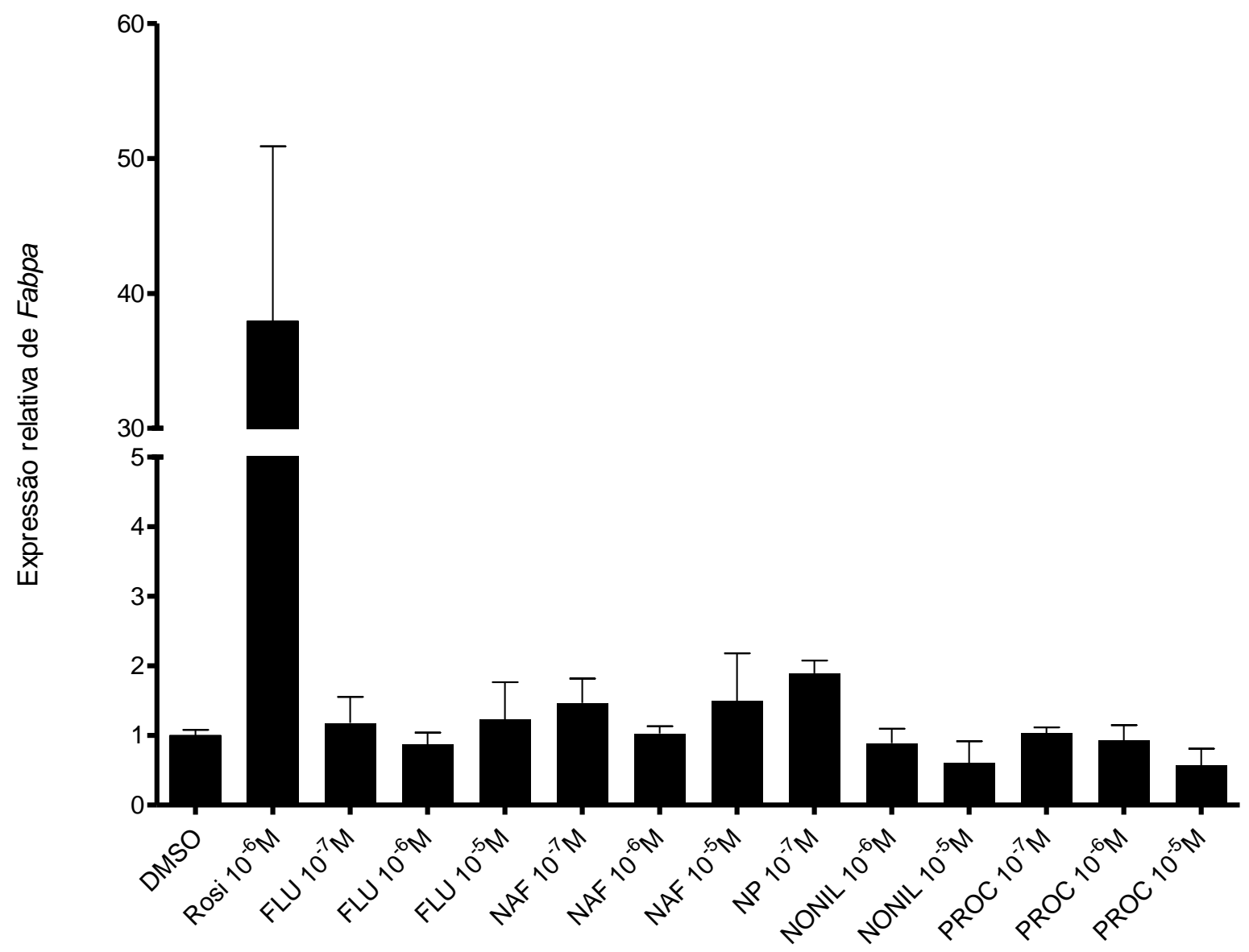

Figura 30. Expressão relativa de Fabpa em células mesenquimais C3H10T1/2. Células C3H10T/2 induzidas a se diferenciar em adipócitos com IBMX $0,5 \mathrm{mM}$, dexametasona $1 \mu \mathrm{M}$ e insulina $1 \mu \mathrm{g} / \mathrm{mL}$ durante dias, e mantidas com insulina $1 \mu \mathrm{g} / \mathrm{mL}$ durante 6 dias. Ao final deste período, foi extraído o RNA total para determinação da expressão relativa de Fabpa, normalizado para Gapdh (gene referência). Dados expressos como média \pm EPM de 2 experimentos independentes. ${ }^{*} \mathrm{p}<0,05$ vs DMSO, pelo teste de Kruskal-Wallis seguido do teste de Dunn. FLU: fluoreno; NAF: naftaleno; NONIL: nonilfenol; PROC: procimidona.

Nos pré-adipócitos 3T3-L1 induzidos a se diferenciar em adipócitos na presença dos diferentes compostos testados, foi observado aumento da expressão do RNAm da proteína 
ligadora de ácidos graxos adipocitária em resposta ao tratamento com a rosiglitazona (Figura 31). Foi observada também tendência de aumento da expressão deste transcrito nas células tratadas com naftaleno $10^{-6} \mathrm{M}$ (Figura 31).

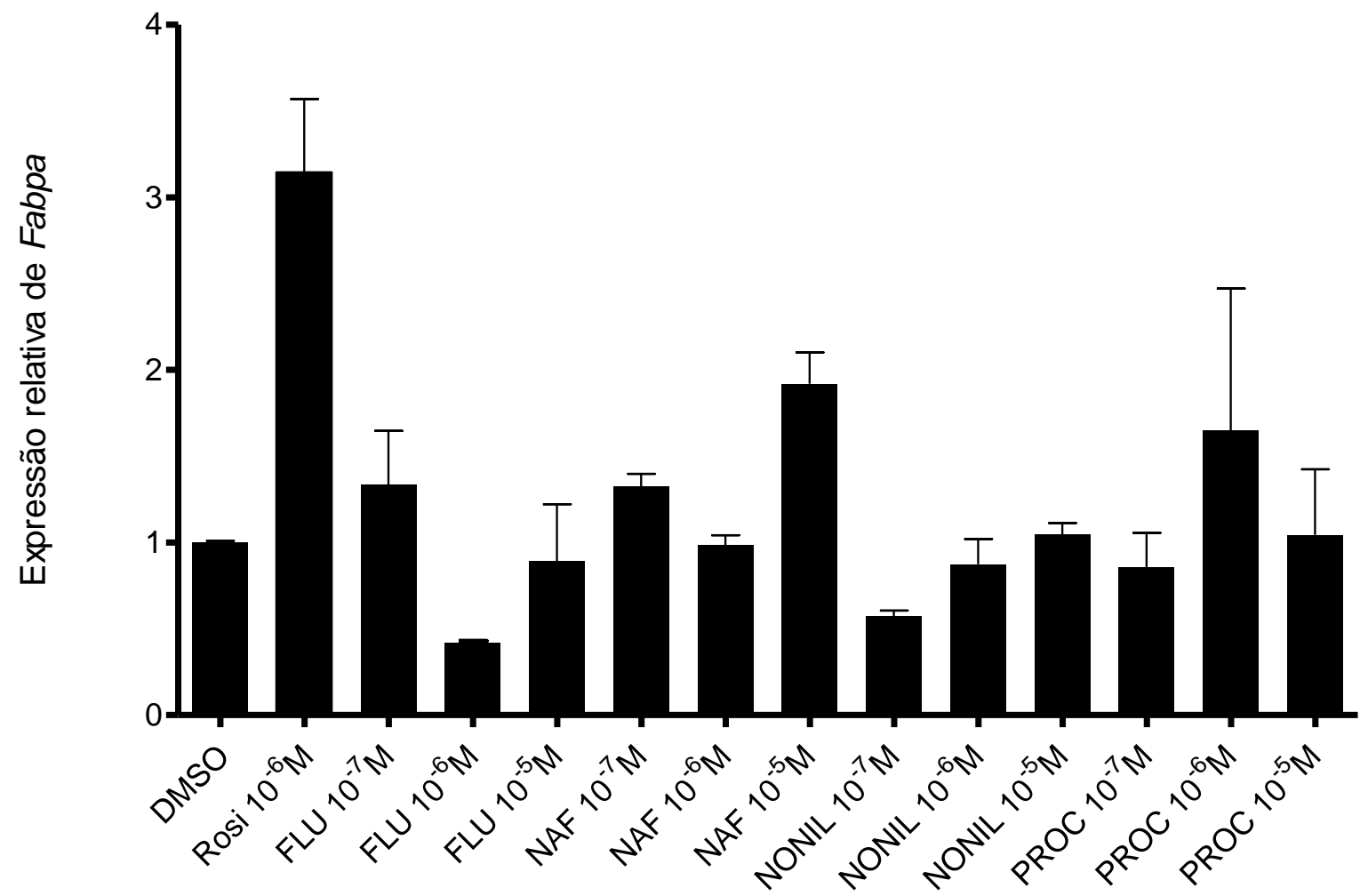

Figura 31. Expressão relativa de Fabpa em células 3T3-L1. Pré-adipócitos 3T3-L1 induzidos a se diferenciar em adipócitos com insulina $10 \mu \mathrm{g} / \mathrm{mL}$ durante dias, e mantidas com insulina $5 \mu \mathrm{g} / \mathrm{mL}$ durante 6 dias. Ao final deste período, foi extraído o RNA total para determinação da expressão relativa de Fabpa, normalizado para Gapdh (gene referência). Dados expressos como média \pm EPM de 2 experimentos independentes. * $\mathrm{p}<0,05$ vs DMSO, pelo teste de Kruskal-Wallis seguido do teste de Dunn. FLU: fluoreno; NAF: naftaleno; NONIL: nonilfenol; PROC: procimidona. 


\section{DISCUSSÃO}

Os DE são amplamente encontrados no ambiente e apresentam potenciais efeitos adversos para a saúde humana, incluindo redução da fertilidade, aumento da incidência e progressão de algumas doenças, como obesidade, diabetes e alguns tipos de câncer. Sua atividade sobre diversos aspectos do sistema endócrino, em especial os receptores hormonais, faz com que sejam considerados hormônios ambientais ou compostos endócrinos ativos (YANG et al., 2015). As fontes de exposição aos DE são diversas e variam amplamente em todo o mundo (DIAMANTI-KANDARAKIS et al., 2009).

A associação entre a exposição aos DE e a ocorrência de obesidade e distúrbios metabólicos a ela associados despertou o interesse pela definição dos mecanismos envolvidos nesta associação. Entre eles, destaca-se o efeito destes compostos sobre receptores nucleares chave da adipogênese e seu efeito sobre a diferenciação e função do adipócito, uma vez que este tipo celular apresenta papel central no desenvolvimento da obesidade. Neste estudo, investigamos o potencial obesogênico do fluoreno, naftaleno e procimidona, por meio da avaliação de seus efeitos nos receptores nucleares PPAR $\gamma$ e GR $\alpha$ e de seus efeitos sobre a adipogênese em cultura. Investigamos também o efeito de outro DE, o nonilfenol, que embora tenha sido descrito como obesogênico in vivo, não foi investigado, para nosso conhecimento, quanto à sua capacidade de atuar no PPAR $\gamma$. Para tanto, foram utilizados os ensaios de gene repórter e de diferenciação de adipócitos.

A diferenciação do pré-adipócito em adipócito é um processo altamente controlado. Fatores de transcrição adipogênicos, incluindo o PPAR $\gamma$, o GR $\alpha$, a proteína ligadora do elemento regulado por esteroides 1c (SREBP-1c) e as C/EBPs (C/AAT enhancer binding proteins) desempenham papel chave na complexa cascata transcricional da adipogênese. $\mathrm{O}$ ajuste do controle da expressão gênica de adipócitos por proteínas C/EBP envolve homo e heterodimerização entre as isoformas $\mathrm{C} / \mathrm{EBP} \alpha, \mathrm{C} / \mathrm{EBP} \beta$ e $\mathrm{C} / \mathrm{EBP} \delta$. Cada isoforma tem um padrão de expressão temporal e espacial distinto durante a diferenciação dos adipócitos. A ligação ao $\mathrm{C} / \mathrm{EBP} \alpha$ ativa os promotores de vários genes dos adipócitos incluindo dos genes que codificam a proteína ligadora de ácidos graxos adipocitária ou aP2, estearoil-CoA dessaturase-1(SCD1), transportador de glicose tipo 4 (GLUT-4), fosfoenolpiruvato carboxiquinase (PEPCK), leptina e o receptor de insulina (GREGOIRE; SMAS; SUL, 1998). 
O C/EBP- $\delta$ tem sua expressão aumentada ex vivo pelos glicocorticoides, o que contribui para a formação de heterodímeros de C/EBP- $\delta$-C/EBP- $\beta$ que, por sua vez, podem aumentar a expressão do PPAR $\gamma$ (GREGOIRE; SMAS; SUL, 1998).

Os ensaios de adipogênese foram feitos com duas linhagens celulares murinas, as células mesenquimais C3H10T1/2 e os pré-adipócitos 3T3-L1. As células multipotentes C3H10T1/2, quando apropriadamente induzidas em cultura com agentes hormonais (dexametasona, insulina e IBMX), tornam-se comprometidas a diferenciarem-se em adipócitos. Os pré-adipócitos murinos 3T3-L1 representam uma linhagem comprometida com a diferenciação adipocitária e mimetizam fielmente o processo de adipogênese in vivo quando adequadamente estimulados, dando origem a células que possuem praticamente todas as características bioquímicas e morfológicas dos adipócitos maduros in vivo. Ambas as linhagens, quando confluentes e submetidas à indução hormonal, sofrem expansão clonal mitótica e depois expressam coordenadamente genes característicos de adipócitos diferenciados (MADRUP; LANE, 1997).

O nonilfenol, um composto da classe dos alquilfenois, tem atraído atenção pela sua prevalência no ambiente e seu potencial de toxicidade. Em ratos expostos ao nonilfenol, é observado estresse oxidativo em órgãos como pâncreas e fígado (JUBENDRADASS; D'CRUZ; MATHUR, 2011; JUBENDRADASS; D'CRUZ; MATHUR, 2012), além de alterações comportamentais em atividade de campo aberto em sua prole, sugerindo que ele seja capaz de afetar o desenvolvimento do SNC (FERGUSON et al., 2000). O nonilfenol também atua como DE, devido à sua capacidade de agir de forma semelhante ao estrogênio. Ele mimetiza a ação hormônio natural $17 \beta$-estradiol no receptor estrogênico e compete com o hormônio endógeno pela ligação ao receptor (YANG et al., 2015).

Mais recentemente, foi caracterizado também o potencial obesogênico do nonilfenol. Hao et al. (2012) observaram que a exposição de camundongos C576BL/6J ao nonilfenol no período perinatal induziu ganho ponderal, aumento da massa adiposa, perfil lipídico desfavorável e aumento da glicemia no período pós-natal. Estes mesmos autores mostraram que o nonilfenol, em combinação com a insulina, induz a diferenciação de pré-adipócitos 3T3-L1 em adipócitos maduros nas concentrações de $10^{-6} \mathrm{M}$ e $10^{-5} \mathrm{M}$, porém não em concentrações mais elevadas. Masuno et al. (2003), entretanto, observaram que o tratamento com nonilfenol (5 e $10 \mu \mathrm{g} / \mathrm{mL}$ ) após a indução da diferenciação (com IBMX, dexametasona e insulina) resultou em aumento da proliferação de adipócitos 3T3-L1 porém inibição de sua diferenciação. Pereira-Fernandes et al. (2013) observaram, na mesma linhagem celular, inibição da adipogênese em célula expostas ao nonilfenol isoladamente durante 10 dias e em 
células expostas ao nonilfenol durante dois dias (indução) e à combinação de nonilfenol e insulina durante 8 dias.

No presente estudo, o efeito adipogênico em cultura do nonilfenol foi investigado em dois modelos, o dos pré-adipócitos 3T3-L1 e o das células mesenquimais C3H10T1/2. Quando estas linhagens foram induzidas a se diferenciar com um estímulo potente, a mistura de um inibidor de fosfodiesterase (IMBX), dexametasona e insulina, foi observado aumento do acúmulo lipídico intracelular nas células 3T3-L1 e, em menor intensidade, nas células mesenquimais. Estes dados caracterizaram o nonilfenol como um DE com atividade adipogênica fraca numa linhagem celular já comprometida com a diferenciação adipocitária, e são semelhantes aos dados de Hao et al. (2012). É possível que a indução da adipogênese por meio de estímulo potente tenha dificultado a identificação de efeito adipogênico fraco do nonilfenol, uma vez que neste protocolo de indução as células tratadas com veículo apresentam aumento do acúmulo lipídico intracelular, sugestivo da diferenciação adipocitária, superior ao de células não induzidas a se diferenciar. Para excluir esta possibilidade, as células 3T3-L1 foram induzidas com estímulo menos potente, apenas com insulina em concentração elevada. Com este protocolo, foi observado aumento mais acentuado do acúmulo lipídico intracelular em resposta ao tratamento com nonilfenol.

A adipogênese em células C3H10T1/2 induzidas a se diferenciar em adipócitos com meio completo (IMBX, dexametasona e insulina) e em pré-adipócitos 3T3-L1 induzidos com meio incompleto (insulina) foi avaliada também pela expressão do transcrito do gene que codifica um marcador do adipócito maduro, a proteína ligadora de ácidos graxos adipocitária, após o período de 10 dias. Observamos aumento de cerca de duas vezes de sua expressão nas células mesenquimais tratadas com $10^{-7} \mathrm{M}$ de nonilfenol, porém não foi observada modificação nas células 3T3-L1. É possível que a cinética de expressão deste transcrito seja diferente entre as duas linhagens estudadas, ao longo do processo de diferenciação em adipócito, e que sua expressão ocorra de forma mais acentuada em um período mais tardio da adipogênese. Isto explicaria a maior indução deste transcrito nas células mesenquimais, porém necessitaria ser comprovado por meio de experimentos que investigassem a cinética da expressão de Fabpa em resposta ao tratamento com compostos adipogênico conhecidos e o nonilfenol nas duas linhagens celulares (MACDOUGALD; LANE, 1995).

Nossos resultados foram semelhantes aos de Hao et al. (2012), em que foi utilizado o mesmo protocolo de indução da diferenciação adipocitária (apenas insulina) e em que a exposição ao nonilfenol ocorreu desde a indução da diferenciação. Entretanto, os resultados contrastam com os de Masuno et al. (2003), descritos anteriormente. É possível que essa 
diferença se deva aos diferentes períodos de exposição ao nonilfenol. No presente estudo, a exposição ocorreu desde o momento da indução, ao passo que no estudo de Masuno et al. (2003) as células 3T3-L1 foram expostas somente após a indução com IBMX, dexametasona e insulina e no estudo de Pereira-Fernandes et al. (2013), durante a indução porém na ausência de outros estímulos para diferenciação. A influência do período de exposição a um estímulo adipogênico, no decorrer do processo de diferenciação adipocitária, já foi sugerida em estudos envolvendo outros DEs. Phillips et al. (1995) observaram que a exposição ao organoclorado TCDD (2,3,7,8-tetraclorodibenzo-p-dioxina) antes ou durante a indução da adipogênese em pré-adipócitos 3T3-L1 inibiu a adipogênese, ao passo que a exposição após a indução não apresentou efeito sobre a diferenciação adipocitária. Biemann et al. (2012) expuseram células mesenquimais murinas C3H10T1/2 ao BPA ou ao DEHP (ftalatos de di-2-etilexila) anteriormente à indução, durante a indução ou ao final do período de diferenciação em adipócitos e observaram que o BPA inibiu a adipogênese em células expostas somente no período anterior à indução e que o DEHP aumentou a adipogênese somente em células expostas durante o período de indução.

Para explorar os possíveis mecanismos envolvidos no efeito adipogênico do nonilfenol, foi investigado seu efeito sobre a atividade transcricional do PPAR $\gamma$ e do GR $\alpha$, por meio do ensaio de gene repórter. Estes dois receptores nucleares foram selecionados por representarem fatores críticos na cascata transcricional da adipogênese (LOWE; O'RAHILLY; ROCHFORD, 2011) e porque os receptores nucleares constituem alvos importantes dos DE.

O PPAR $\gamma$ está envolvido em diversos processos fisiológicos, principalmente no metabolismo de lipídeos e na resposta inflamatória. Este aspecto o tornou um alvo atraente para estudo acerca da fisiopatologia da obesidade. A capacidade de armazenamento de lipídeos a partir da ativação do PPAR $\gamma$ é decorrente do aumento da expressão de genes que codificam proteínas que participam da síntese e armazenamento lipídico, como a proteína ligadora de ácidos graxos (FABP-A ou aP2) (SEMPLE; CHATTERJEE; O'RAHILLY, 2006). Os glicocorticoides, por meio da sinalização via receptor de glicocorticoides, também são implicados no desenvolvimento da obesidade (BJORNTORP; ROSMOND, 2000).

Neste estudo, não foi observado efeito do nonilfenol no PPAR $\gamma$ e no GR $\alpha$. É possível que o efeito adipogênico deste DE, observado neste estudo, seja devido à ação em outros fatores ou vias envolvidos na diferenciação adipocitária. De fato, o efeito de outros DE sobre a adipogênese foi caracterizado como decorrente de vias independentes do PPAR $\gamma$ ou GR $\alpha$, como a ativação do receptor estrogênico (OHLSTEIN et al., 2014) e da via da 
fosfatidilinositol 3-quinase e proteína quinase B ou Akt (MASUNO et al., 2005), no caso do BPA, e do receptor aril hidrocarboneto, no caso das bifenilas policloradas (ARSENESCU et al., 2008; GADUPUDI et al., 2015).

A mesma investigação foi realizada para os outros três compostos, o fluoreno, o naftaleno e a procimidona. Esses últimos foram selecionados para o estudo devido ao seu elevado grau de exposição humana e por não haver dados na literatura que correlacionem esses DE com a obesidade por meio de estudos pré-clínicos ou clínicos.

O fluoreno e o naftaleno pertencem a mesma família dos PAH. São originados a partir da combustão incompleta de materiais orgânicos e estão amplamente distribuídos no ambiente, a partir da poluição do ar da fumaça do cigarro. Assim, o grau de exposição humana a esses compostos é elevado (LI et al., 2008; JIN et al., 2014). Alguns estudos demonstraram a capacidade dos $\mathrm{PAH}$ em atuar como DE em processos dependentes do estrogênio (OHURA et al., 2010; SIEVERS et al., 2013). Além disso, em estudos observacionais é observada a associação entre a exposição a PAH e a ocorrência de obesidade em humanos. Scinicariello e Buser (2014) identificaram associação entre a concentração urinária de metabólitos de PAH totais e do naftaleno e a presença de aumento do índice de massa corporal, circunferência abdominal e presença de obesidade entre crianças entre 6 e 11 anos e adolescentes. Kim et al. (2014) observaram a mesma associação entre a exposição a PAH totais e a ocorrência de obesidade em indivíduos entre 6 e 18 anos. A relação de causalidade entre estes dois aspectos e os eventuais mecanismos envolvidos na associação, entretanto, não foram explorados em ensaios envolvendo cultura de células.

O fluoreno e o naftaleno, neste estudo, mostraram-se indutores fracos da diferenciação adipocitária, avaliada pelo acúmulo lipídico intracelular e pela expressão do transcrito Fabpa, nas células comprometidas com adipogênese (pré-adipócitos murinos 3T3-L1) e induzidas a se diferenciar somente em presença de insulina. Seu efeito não foi observado em células mesenquimais C3H10T1/2. Além disso, não induziram a atividade transcricional do PPAR $\gamma$ ou GRa. Esses dados, em conjunto, sugerem seu baixo potencial adipogênico, embora este aspecto deva ser confirmado in vivo.

A procimidona é um fungicida que vem sendo usado na agricultura há vários anos (HOSOKAWA et al., 1993) e está presente, sobretudo, em produtos preparados com frutas para consumo humano (OSTBY et al., 1999). Estudos prévios definiram a procimidona como um anti-androgênico típico, pois possui a capacidade de inibir competitivamente a ligação do androgênio ao AR, impedindo assim a expressão de genes regulados pelos androgênios 
(OSTBY et al., 1999). Para conhecimento dos pesquisadores envolvidos neste estudo, não há descrições prévias, clínicas ou pré-clínicas, de sua associação com a obesidade.

Neste estudo, não foi observado efeito da procimidona sobre a diferenciação de préadipócitos 3T3-L1 ou células mesenquimais murinas induzidos a se diferenciar com meio completo (IBMX, dexametasona e insulina). As células 3T3-L1 induzidas com meio incompleto (somente insulina) apresentaram discreto aumento do acúmulo intracelular de lipídeos, porém não houve modificação da expressão do transcrito Fabpa. Não foi observado, ainda efeito sobre a atividade transcricional do PPAR $\gamma$ ou GR $\alpha$. De forma semelhante aos dados obtidos nos ensaios com o naftaleno e nonilfenol, estes resultados sugerem potencial adipogênico fraco da procimidona, observado somente em uma linhagem já comprometida com a diferenciação adipocitária e induzida a se diferenciar somente com a insulina, por vias independentes da ativação do PPAR $\gamma$ ou GR $\alpha$.

Este estudo buscou investigar o potencial obesogênico do fluoreno, naftaleno, nonilfenol e procimidona em ensaios celulares. Embora a adipogênese seja um mecanismo reconhecido dos obesogênicos ambientais (GRUN; BLUMBERG, 2012), a determinação da atividade obesogênica de um DE por meio de ensaios celulares (transativação e diferenciação de adipócitos) apresenta uma série de limitações. Os DE podem interferir em qualquer aspecto da ação hormonal e os seus mecanismos de ação são ainda muito complexos. Eles podem ligar-se a receptores de hormônios e exercer ação agonista ou antagonista, direta ou indireta, ou podem ligar-se a sítios alostéricos e produzir efeitos inesperados mesmo em concentrações muito baixas. Podem, ainda, interferir na síntese ou no metabolismo hormonal, eu seu transporte ou degradação (ZOELLER et al., 2012). Desta forma, a atividade obesogênica de um DE não pode ser determinada somente pela investigação de seu potencial adipogênico em cultura de células.

O PPAR $\gamma$ e o GR $\alpha$, investigados neste estudo, constituem fatores de transcrição críticos para a adipogênese. Entretanto, há outras vias em que os DEs podem atuar para determinar a obesidade. Assim, é possível que o fraco potencial adipogênico dos compostos investigados neste estudo possa ser devido a ação em outras vias que não os receptores estudados nesse trabalho. Os receptores nucleares dos esteroides sexuais também influenciam o desenvolvimento do tecido adiposo. Estudos em modelos de deleção homozigota (knockout) do receptor alfa de estrogênio $(\alpha E R K O)$ e do receptor de androgênio (ARKO) confirmam o papel dos esteroides sexuais na regulação da hipertrofia e hiperplasia dos adipócitos, bem como no dimorfismo sexual da distribuição de tecido adiposo e na remodelação de depósitos específicos de tecido adiposo (DANILOVICH et al., 2000; MURATA et al., 2002; HEINE et 
al., 2000; MATSUMOTO et al., 2009). Fisiologicamente, esteroides sexuais, em conjunto com hormônios peptídicos como o hormônio do crescimento, mobilizam estoques de lipídios e antagonizam as ações da insulina e do cortisol no acúmulo de lipídios (BLUMBERG; GRUN, 2009).

Outro mecanismo para justificar a capacidade obesogênica dos DE seria a interferência com os mecanismos centrais que coordenam a resposta do organismo às flutuações nutricionais diárias, como o eixo hipotálamo-pituitária-adrenal (HPA). O HPA exerce seu papel no controle do apetite, e apresenta papel fundamental para prevenir a hiperfagia e regular a homeostase energética (BLUMBERG; GRUN, 2009). A hiperfagia resultante de desregulação de centros hipotalâmicos de controle do apetite seria uma via potencial em que os DE poderiam atuar para comprometer a homeostase energética (BLUMBERG ;GRUN, 2009).

Uma característica peculiar dos DE são as curvas dose-resposta ou concentraçãoefeito não monotônicas (BLUMBERG ; GRUN, 2009). Neste estudo, procurou-se testar uma ampla faixa de concentrações dos DE investigados, tanto nos ensaios de gene repórter quanto nos ensaios de adipogênese. Embora não tenha sido observada atividade do fluoreno, naftaleno, nonilfenol e procimidona no PPAR $\gamma$ ou GR $\alpha$, em geral foi observado efeito adipogênico fraco nas concentrações mais elevadas de cada DE.

Em geral, os DE comportam-se como tóxicos metabólicos em elevadas concentrações, muitas vezes levando a perda de peso ou restrição de crescimento. Em concentrações inferiores, mais semelhantes às resultantes de exposições ambientais, estes efeitos podem ser invertidos. Entretanto, além da concentração, deve-se considerar também a influência de outros fatores sobre o efeito dos DE, incluindo tempo de exposição, gênero e predisposição genética. Os efeitos podem demorar a aparecer e variam entre as populações. $O$ atraso na resposta e a dificuldade experimental em estabelecer a causa e o efeito para a associação entre fatores ambientais e ocorrência de obesidade podem limitar a observação do efeito obesogênico dos DE. O aumento do risco de obesidade devido ao tabagismo materno prénatal certamente fornece uma prova-de-conceito de que a desregulação em longo prazo da homeostase metabólica é relevante (BLUMBERG; GRUN, 2009). 


\section{CONCLUSÃO}

- O fluoreno, naftaleno, nonilfenol e procimidona apresentaram baixo potencial adipogênico em cultura de células.

- O fluoreno, naftaleno e procimidona não comprometeram a viabilidade de células HeLa nas concentrações testadas $\left(10^{-12}\right.$ a $\left.10^{-4} \mathrm{M}\right)$; o nonilfenol não comprometeu a viabilidade de células HeLa nas concentrações de $10^{-12}$ a $10^{-5} \mathrm{M}$, porém reduziu sua viabilidade na concentração de $10^{-4} \mathrm{M}$.

- O nonilfenol, porém não o fluoreno, naftaleno e procimidona, apresentaram efeito adipogênico fraco em pré-adipócitos murinos 3T3-L1 induzidos a se diferenciar, em cultura, com IBMX, dexametasona e insulina.

- O fluoreno, naftaleno, nonilfenol e procimidona apresentaram efeito adipogênico fraco em pré-adipócitos murinos 3T3-L1 induzidos a se diferenciar, em cultura, com insulina.

- O fluoreno, naftaleno, nonilfenol e procimidona não induziram a diferenciação de células mesenquimais murinas $\mathrm{C} 3 \mathrm{H} 10 \mathrm{~T} 1 / 2$ em adipócitos, em cultura.

- O fluoreno, naftaleno, nonilfenol e procimidona não apresentaram atividade agonista nos receptores PPAR $\gamma$ e GR $\alpha$.

- O naftaleno, nonilfenol e procimidona não apresentaram atividade antagonista nos receptores PPAR $\gamma$ e GR $\alpha$. 


\section{REFERÊNCIAS}

ALBERTS, B. et al. Molecular Biology of the Cell. 4th edition. New York: Garland Science; 2002. Disponível em: <http://www.ncbi.nlm.nih.gov/books/NBK26813/> Acesso em: 15 de julho de 2015.

ARSENESCU, V. et al. Polychlorinated biphenyl-77 induces adipocyte differentiation and proinflammatory adipokines and promotes obesity and atherosclerosis. Environ Health Perspect. v. 116, p. 761-8, 2008.

BAILLIE-HAMILTON, P.F. Chemical toxins: a hypothesis to explain the global obesity epidemic. J Altern Complement Med.,v.8, p. 185-92, apr 2002. Review.

BELCHER, S. M. et al. In vitro assessment of human nuclear hormone receptor activity and cytotoxicity of the flame retardant mixture FM 550 and its triarylphosphate and brominated components. Toxicol Lett, v. 228, n. 2, p. 93-102, jul 2014.

BIEMANN, R. et al. Endocrine disrupting chemicals affect the adipogenic differentiation of mesenchymal stem cells in distinct ontogenetic windows. Biochem Biophys Res Commun. v.;417, p.747-52, 2012.

BJORNTORP, P.; ROSMOND, R. Obesity and cortisol. Nutrition, v. 16, p. 924-936, 2000.

BOSTROM, C. E. et al. Cancer risk assessment, indicators, and guidelines for polycyclic aromatic hydrocarbons in the ambient air. In: (Ed.). Environ Health Perspect. United States, v.110, Suppl 3, p.451-88, 2002.

CASALS-CASAS, C.; FEIGE, J. N.; DESVERGNE, B. Interference of pollutants with PPARs: endocrine disruption meets metabolism. In: (Ed.). Int J Obes (Lond). England, v.32, Suppl 6, p.S53-61, 2008.

COLMERS, I.N.et al. Use of thiazolidinediones and the risk of bladder cancer among people with type 2 diabetes: a meta-analysis. CMAJ., v.184, p. E675-83, 2012.

DALMAS, E.; CLEMENT, K.; GUERRE-MILLO, M. Defining macrophage phenotype and function in adipose tissue. In: (Ed.). Trends Immunol. England, v.32, p.307-14, 2011.

DANILOVICH, N.et al. Estrogen deficiency, obesity, and skeletal abnormalities in folliclestimulating hormone receptor knockout (FORKO) female mice. Endocrinology, v. 141, p. 4295-4308, 2000.

DE COSTER, S.; VAN LAREBEKE, N. Endocrine-disrupting chemicals: associated disorders and mechanisms of action. J Environ Public Health, v. 2012, p. 713696, 2012. 
DHURANDHAR, E. J.; KEITH, S. W. The aetiology of obesity beyond eating more and exercising less. Best Pract Res Clin Gastroenterol, v. 28, n. 4, p. 533-44, aug 2014.

DIAMANTI-KANDARAKIS, E. et al. Endocrine-disrupting chemicals: an Endocrine Society scientific statement. In: (Ed.). Endocr Rev. United States, v.30, p.293-342, 2009.

DIVOUX, A. et al. Fibrosis in human adipose tissue: composition, distribution, and link with lipid metabolism and fat mass loss. In: (Ed.). Diabetes. United States, v.59, p.2817-25, 2010.

ELOBEID, M. A.; ALLISON, D. B. Putative environmental-endocrine disruptors and obesity: a review. In: (Ed.). Curr Opin Endocrinol Diabetes Obes. England, v.15, p.403-8, 2008.

FARIA, C. D.; LONGUI, C. A. [Molecular aspects of glucocorticoid sensitivity]. In: (Ed.). Arq Bras Endocrinol Metabol. Brazil, v.50, p.983-95, 2006.

FERGUSON, S. A. et al. Maternal and offspring toxicity but few sexually dimorphic behavioral alterations result from nonylphenol exposure. Neurotoxicol. Teratol, v. 22, p. 583-591, 2000.

FLIER, J. S. et al. Severely impaired adipsin expression in genetic and acquired obesity. Science, v. 237, n. 4813, p. 405-8, jul 1987.

FRAYN, K. N. et al. Integrative physiology of human adipose tissue. Int J Obes Relat Metab Disord, England, v.27, p.875-88, 2003.

GADUPUDI, G. et al PCB126 inhibits adipogenesis of human preadipocytes. Toxicol In Vitro. v. 29, p. 132-41, 2015.

GOLDMAN, R. et al. Smoking increases carcinogenic polycyclic aromatic hydrocarbons in human lung tissue. Cancer Res. v. 61, p. 6367-71, 2001.

GONG, Y.; HAN, X. D. Effect of nonylphenol on steroidogenesis of rat Leydig cells. Chemosphere, v. 41, n. 5, p. 705-15, 2006.

GRAY, L. E. JR; KELCE, W.R. Latent effects of pesticides and toxic substances on sexual differentiation of rodents. Toxicol Ind Health, v. 12, n. 3-4, p. 515-31, may-aug 1996.

GREEN, H.; MEUTH, M. An established pre-adipose cell line and its differentiation in culture. Cell. v. 3, n. 2, p. 127-33, 1974. 
GREGOIRE, F. M.; SMAS, C. M.; SUL, H. S. Understanding adipocyte differentiation. Physiol Rev, v. 78, n. 3, p. 783-809, Jul 1998.

GREGOR, M. F; Hotamisligil, G.S. Inflammatory mechanisms in obesity. Annu Rev Immunol. v. 29, p. 41545, 2011.

GRIMBLE, R. F. Inflammatory status and insulin resistance. Curr Opin Clin Nutr Metab Care, v. 5, n. 5, p. $551-9,2002$.

GRÜN F, BLUMBERG B. Endocrine disrupters as obesogens. Mol Cell Endocrinol., v. 304, p.19-29, 2009. Review.

GRUN, F.; BLUMBERG, B. Environmental obesogens: organotins and endocrine disruption via nuclear receptor signaling. In: (Ed.). Endocrinology. United States, v.147, p.S50-5, 2006.

GRUN, F. et al. Endocrine-disrupting organotin compounds are potent inducers of adipogenesis in vertebrates. In: (Ed.). Mol Endocrinol. United States, v.20, p.2141-55, 2006.

GRUNDY, S. M. et al. Definition of metabolic syndrome: Report of the National Heart, Lung, and Blood Institute/American Heart Association conference on scientific issues related to definition. In: (Ed.). Circulation. United States, v.109, p.433-8, 2004.

GUAN, H. P. et al. Corepressors selectively control the transcriptional activity of PPARgamma in adipocytes. In: (Ed.). Genes Dev. United States, v.19, p.453-61, 2005.

HAO, C. J. et al. The endocrine disruptor 4-nonylphenol promotes adipocyte differentiation and induces obesity in mice. In: (Ed.). Cell Physiol Biochem. Switzerland: Basel., v.30, p.382-94. 2012.

HARITASH, A. K.; KAUSHIK, C. P. Biodegradation aspects of polycyclic aromatic hydrocarbons (PAHs): a review. In: (Ed.). J Hazard Mater. Netherlands, v.169, p.1-15, 2009.

HEINE, P.A. et al. Increased adipose tissue in male and female estrogen receptor-alpha knockout mice. Proc. Natl. Acad. Sci. U.S.A., v. 97, p. 12729-12734, 2000.

HEUDORF, U.; MERSCH-SUNDERMANN, V.; ANGERER, J. Phthalates: toxicology and exposure. In: (Ed.). Int J Hyg Environ Health. Germany, v.210, p.623-34, 2007.

HOSOKAWA, S. et al. The affinity of procymidone to androgen receptor in rats and mice. J Toxicol Sci., v. 18, p. 83-93, 1993. 
HUANG, W. et al. Levels of 1-hydroxypyrene and other monohydroxy polycyclic aromatic hydrocarbons in children: a study based on U.S. reference range values. In: (Ed.). Toxicol Lett. Netherlands, v.163, p.10-9, 2006.

INTERNATIONAL AGENCY FOR RESEARCH ON CANCER (IARC). Some non-heterocyclic polycyclic aromatic hydrocarbons and some related exposures. Monogr Eval Carcinog Risks Hum . v. 9, p. 765-71, 2010.

IMPERATO-MCGINLEY, J. et. al Comparison of the effects of the 5 alpha-reductase inhibitor finasteride and the antiandrogen flutamide on prostate and genital differentiation: dose-response studies. Endocrinology.;v. 131, p. 1149-56, 1992.

IRIGARAY, P. et al. Benzo[a]pyrene impairs beta-adrenergic stimulation of adipose tissue lipolysis and causes weight gain in mice. A novel molecular mechanism of toxicity for a common food pollutant. FEBS J. v. 273, p. 1362-72, 2006.

JIN, Y. et al. Sub-chronically exposing mice to a polycyclic aromatic hydrocarbon increases lipid accumulation in their livers. Environ Toxicol Pharmacol, v. 38, n. 2, p. 353-63, 2014.

JUBENDRADASS, R.; D'CRUZ, S.C.; MATHUR, P.P. Short-term exposure to nonylphenol induces pancreatic oxidative stress and alters liver glucose metabolism in adult female rats. J Biochem Mol Toxicol. v. 25, n. 2, p. 77-83, mar/apr 2011.

JUBENDRADASS, R.; D'CRUZ, S.C.; MATHUR, P.P. Long-term exposure to nonylphenol affects insulin signaling in the liver of adult male rats. Hum Exp Toxicol. Sep. v. 31, n. 9, p. 868-876, 2012.

KAROUTSOU, E; POLYMERIS, A. Environmental endocrine disruptors and obesity. Endocr Regul. v. 46, n. 1, p. 37-46, jan 2012.

KELCE, W. R. et al. Environmental hormone disruptors: evidence that vinclozolin developmental toxicity is mediated by antiandrogenic metabolites. Toxicol Ind Health, v. 126, n. 2, p. 276-85, jun 1994.

KERSHAW, E. E.; FLIER, J. S. Adipose tissue as an endocrine organ. In: (Ed.). J Clin Endocrinol Metab. United States, v.89, p.2548-56, 2004.

KERSTEN, S. Peroxisome proliferator activated receptors and obesity. In: (Ed.). Eur J Pharmacol. Netherlands, v.440, p.223-34, 2002.

KIM, M. J. et al. Fate and complex pathogenic effects of dioxins and polychlorinated biphenyls in obese subjects before and after drastic weight loss. Environ Health Perspect, v. 119, n. 3, p. 377-83, mar 2011. 
KNOUFF, C.; AUWERX, J. Peroxisome proliferator-activated receptor-gamma calls for activation in moderation: lessons from genetics and pharmacology. In: (Ed.). Endocr Rev. United States, v.25, p.899-918, 2004.

LAITMAN, C.J. DES exposure and the aging woman: mothers and daughters. Curr Womens Health Rep.v. 2, p. 390-3, 2002.

LI, D.K. et al.Urine bisphenol-A level in relation to obesity and overweight in school-age children. PLoS One. v.8, p. e65399, 2013.

LI, Z. et al. Concentration and profile of 22 urinary polycyclic aromatic hydrocarbon metabolites in the US population. In: (Ed.). Environ Res. United States, v.107, p.320-31, 2008.

LIU, X. et al. Effects of nonylphenol exposure on expression of cell receptors and secretory function in mouse Sertoli TM4 cells. Toxicol Lett, v. 37, n. 2, p. 608-16, mar 2014.

LOPEZ-ESPINOSA, M.J. et al. Nonylphenol and octylphenol in adipose tissue of women in Southern Spain. Reprod Biol Endocrinol, v. 76, n. 6, p. 847-52, aug 2009.

LOWE, C.E.; O'RAHILLY, S.; ROCHFORD, J.J.. Adipogenesis at a glance. J Cell Sci. 2011 Aug 15;124(Pt 16):2681-6. doi: 10.1242/jcs.079699. Review. Erratum in: J Cell Sci. 2011 Nov 1;124(Pt 21):3726.

MANDRUP, S.;LANE, M. D. Regulating adipogenesis. J. Biol. Chem. v. 272, p. 5367-5370, 1997.

MAFFINI, M. V. et al. Endocrine disruptors and reproductive health: the case of bisphenol-A. In: (Ed.). Mol Cell Endocrinol. Ireland, v.254-255, p.179-86, 2006.

MASUNO, H. et al. Bisphenol A in combination with insulin can accelerate the conversion of 3T3-L1 fibroblasts to adipocytes. J Lipid Res, v. 43, n. 5, p. 676-84, 2002.

MASUNO, H. et al. Effect of 4-nonylphenol on cell proliferation and adipocyte formation in cultures of fully differentiated 3T3-L1 cells. In: (Ed.). Toxicol Sci. United States, v.75, p.314-20, 2003.

MASUNO; H. et al. Bisphenol a accelerates terminal differentiation of 3T3-L1 cells into adipocytes through the phosphatidylinositol 3-kinase pathway. Toxicol Sci.,v. 84, p. 319-27, 2005.

MATSUMOTO, T. et al. Androgen receptor functions from reverse genetic models. J. Steroid Biochem. Mol. Biol. v. 85, p. 95-99, 2003. 
MACDOUGALD, O.A; LANE, M.D. Transcriptional regulation of gene expression during adipocyte differentiation. Annu Rev Biochem, v. 64, p. 345-73, 1995.

MCEWAN, I. J.; WRIGHT, A. P.; GUSTAFSSON, J. A. Mechanism of gene expression by the glucocorticoid receptor: role of protein-protein interactions. Bioessays, v. 19, n. 2, p. 153-60, feb 1997.

MICHALIK, L. et al. International Union of Pharmacology. LXI. Peroxisome proliferator-activated receptors. Pharmacol Rev.v. 58, p. 726-41, 2006.

MINISTÉRIO DA SAÚDE. Vigitel 2014: Obesidade estabiliza no Brasil, mas excesso de peso aumenta. Portal da Saúde. Disponivel em: <http://portalsaude.saude.gov.br/index.php/o-

ministerio/principal/secretarias/svs/noticias-svs/17455-obesidade-estabiliza-no-brasil-mas-excesso-de-pesoaumenta>. Acesso em: 06 de junho de 2015.

MOGI, M.; IWAI, M.; HORIUCHI, M. Emerging concept of adipogenesis regulation by the renin-angiotensin system. Hypertension. v. 48, p. 1020-2, 2006.

MURATA, Y.et.al.. Effect of estrogen deficiency in the male: the ArKO mouse model. Mol. Cell Endocrinol. v. 193, p. 7-12, 2002.

NEEL, B.A.; SARGIS, R.M. The paradox of progress: environmental disruption of metabolism and the diabetes epidemic. Diabetes. v. 60, p. 1838-48, 2011.

NELLEMANN, C. et al. The combined effects of vinclozolin and procymidone do not deviate from expected additivity in vitro and in vivo. Toxicol Sci. v. 71, p. 251-62, 2003.

NTAMBI, J.M.; YOUNG-CHEUL, K. Adipocyte differentiation and gene expression. J Nutr. v. 130, p.3122S3126S, 2000. .

NISSEN, S.E.; WOLSKI, K. Effect of rosiglitazone on the risk of myocardial infarction and death from cardiovascular causes. N Engl J Med. v. 14, p. 2457-71, 2007. Erratum in: N Engl J Med. v. 357, p.100, 2007.

ODERMATT, A. et al. Disruption of glucocorticoid action by environmental chemicals: potential mechanisms and relevance. In: (Ed.). J Steroid Biochem Mol Biol. England, v.102, p.222-31, 2006.

OHLSTEIN, J.F. et al. Bisphenol A enhances adipogenic differentiation of human adipose stromal/stem cells. J Mol Endocrinol.v. 53, p. 345-53, 2014. 
OHURA, T. et al. Differential action of chlorinated polycyclic aromatic hydrocarbons on aryl hydrocarbon receptor-mediated signaling in breast cancer cells. Environ Toxicol, v. 25, n. 2, p. 180-7, apr 2010.

OSTBY, $\mathrm{J}$ et al.The fungicide procymidone alters sexual differentiation in the male rat by acting as an androgenreceptor antagonist in vivo and in vitro. v. 15, n. 1-2, p. 80-93, jan-mar 1999.

OTTO, T.C.; LANE, M.D. Adipose development: from stem cell to adipocyte. Crit Rev Biochem Mol Biol. v. 40, n. 4, p. 229-42, 2005.

PEEK, C. B. et al. Nutrient sensing and the circadian clock. In: (Ed.). Trends Endocrinol Metab. United States: 2012 Elsevier Ltd, v.23, p.312-8, 2012.

PEIFFER, J. et al. Neurobehavioral toxicity of a repeated exposure (14 days) to the airborne polycyclic aromatic hydrocarbon fluorene in adult Wistar male rats. In: (Ed.). PLoS One. United States, v.8, p.e71413, 2013.

PEREIRA-FERNANDES, A. et al.Evaluation of a screening system for obesogenic compounds: screening of endocrine disrupting compounds and evaluation of the PPAR dependency of the effect. PLoS One. v. 8, p. e77481, 2013.

PHILLIPS, M. et al.Inhibition of 3T3-L1 adipose differentiation by 2,3,7,8-tetrachlorodibenzo-p-dioxin. J. Cell Sci. v. 108, p. 395-402, 1995.

PREUSS, R.; ANGERER, J.; DREXLER, H. Naphthalene--an environmental and occupational toxicant. Int Arch Occup Environ Health, v. 76, n. 8, p. 556-76, 2003.

PUBCHEM, 2015. Disponível em:< https://pubchem.ncbi.nlm.nih.gov/> Acesso em: 15 de julho de 2015.

QUEIROZ, J. C. et al. [Control of adipogenesis by fatty acids]. Arq Bras Endocrinol Metabol, v. 53, n. 5, p. 582-94, jul 2009.

RADICE, S. et al. Estrogenic activity of procymidone in primary cultured rainbow trout hepatocytes (Oncorhynchus mykiss). v. 16, n. 4, p. 475-80, aug 2002.

RADICE, S.F.R. et al Estrogenic activity of procymidone in rainbow trout (Oncorhynchus mykiss) hepatocytes: a possible mechanism of action. Chemosphere, v. 147, n. 2, p. 185-93, 2004.

REGNIER, S.M.; SARGIS, R.M. Adipocytes under assault: environmental disruption of adipose physiology.

Biochim Biophys Acta, v. 1842, n. 3, p. 520-33, mar 2014. 
ROBINSON-RECHAVI, M.E.G.H.; LAUDET, V. The nuclear receptor superfamily. Chem Biol Interact, v. 116, n. Pt 4, p. 585-6, 2003.

ROSEN, E.D. et al. Transcriptional regulation of adipogenesis. Genes Dev. v. 14, n. 11, p. 1293-307, jun 2000.

RUBIN, B. S. et al. Perinatal exposure to low doses of bisphenol A affects body weight, patterns of estrous cyclicity, and plasma LH levels. In: (Ed.). Environ Health Perspect. United States, v.109, p.675-80, 2001.

SAMANTA, S.K.; SINGH, O.V.; JAIN, R.K. Polycyclic aromatic hydrocarbons: environmental pollution and bioremediation. In: (Ed.). Trends Biotechnol. England, v.20, p.243-8, 2002.

SANTODONATO, J. Review of the estrogenic and antiestrogenic activity of polycyclic aromatic hydrocarbons: relationship to carcinogenicity. In: (Ed.). Chemosphere. England, v.34, p.835-48, 1997.

SARGIS, R. M. et al. Environmental endocrine disruptors promote adipogenesis in the 3T3-L1 cell line through glucocorticoid receptor activation. In: (Ed.). Obesity (Silver Spring). United States, v.18, p.1283-8, 2010.

SCINICARIELLO, F.; BUSER, M. C. Urinary polycyclic aromatic hydrocarbons and childhood obesity: NHANES (2001-2006). Environ Health Perspect, v. 122, n. 3, p. 299-303, mar 2014.

SEMPLE, R.K.; CHATTERJEE, V.K.; O'RAHILLY, S. PPAR gamma and human metabolic disease. J Clin Invest. v. 116, p. 581-9, 2006. Review.

SHEEHAN, D. M. et al. No threshold dose for estradiol-induced sex reversal of turtle embryos: how little is too much? Environ Health Perspect, v. 107, n. 2, p. 155-9, feb 1999.

SHINOMIYA, N.; SHINOMIYA, M. Dichlorodiphenyltrichloroethane suppresses neurite outgrowth and induces apoptosis in PC12 pheochromocytoma cells. In: (Ed.). Toxicol Lett. Netherlands, v.137, p.175-83, 2003.

SIEVERS, C. K. et al. Differential action of monohydroxylated polycyclic aromatic hydrocarbons with estrogen receptors alpha and beta. In: (Ed.). Toxicol Sci. United States, v.132, p.359-67, 2013.

SIITERI, P. K. Adipose tissue as a source of hormones. Am J Clin Nutr, v. 45, n. 1 Suppl, p. 277-82, jan 1987.

STAHLHUT, R. W. et al. Concentrations of urinary phthalate metabolites are associated with increased waist circumference and insulin resistance in adult U.S. males. Environ Health Perspect, v. 115, n. 6, p. 876-82, jun 2007. 
STOCKERT, J. C. et al. MTT assay for cell viability: Intracellular localization of the formazan product is in lipid droplets. Acta Histochem, v. 114, n. 8, p. 785-96, 2012.

SUN, H. et al. Carbaryl, 1-naphthol and 2-naphthol inhibit the beta-1 thyroid hormone receptor-mediated transcription in vitro. In: (Ed.). Toxicology. Ireland, v.249, p.238-42, 2008.

TABB, M. M.; BLUMBERG, B. New modes of action for endocrine-disrupting chemicals. In: (Ed.). Mol Endocrinol. United States, v.20, p.475-82, 2006.

TAVARES, V.; HIRATA, M.H.; HIRATA, R.D. [Peroxisome proliferator-activated receptor gamma (PPARgamma): molecular study in glucose homeostasis, lipid metabolism and therapeutic approach]. Arq Bras Endocrinol Metabol. v. 51, p. 526-33, 2007. Review. Portuguese.

TORDJMAN, J. et al. Structural and inflammatory heterogeneity in subcutaneous adipose tissue: relation with liver histopathology in morbid obesity. In: (Ed.). J Hepatol. England: A 2012 European Association for the Study of the Liver. v.56, p.1152-8, 2012.

VALENTINO, R. et al. Bisphenol-A impairs insulin action and up-regulates inflammatory pathways in human subcutaneous adipocytes and 3T3-L1 cells. PLoS One. v. 8, p. e82099, 2013.

VINGGAARD, A. M.; HNIDA, C.; LARSEN, J. C. Environmental polycyclic aromatic hydrocarbons affect androgen receptor activation in vitro. In: (Ed.). Toxicology. Ireland, v.145, p.173-83, 2000.

WANG, Y.L. et al. Multimedia fate and source apportionment of polycyclic aromatic hydrocarbons in a coking industry city in Northern China. Environ Pollut. v. 181, p. 115-21, 2013.

WEISBERG, S. P. et al. Obesity is associated with macrophage accumulation in adipose tissue. In: (Ed.). J Clin Invest. United States, v.112, p.1796-808, 2003.

WENGER, D. et al. In vitro estrogenicity of ambient particulate matter: contribution of hydroxylated polycyclic aromatic hydrocarbons. J Appl Toxicol, v. 29, n. 3, p. 223-32, 2009.

WILLSON, T. M. et al. The PPARs: from orphan receptors to drug discovery. J Med Chem, v. 43, n. 4, p. 527$50,2000$.

WOLF, C.JR. et al. Administration of potentially antiandrogenic pesticides (procymidone, linuron, iprodione, chlozolinate, p,p'-DDE, and ketoconazole) and toxic substances (dibutyl- and diethylhexyl phthalate, PCB 169, and ethane dimethane sulphonate) during sexual differentiation produces diverse profiles of reproductive malformations in the male rat. v. 15 , n. 1-2, p. 94-118, 1999. 
WORLD HEALTH ORGANIZATION. Obesity. Disponível em: <http://www.who.int/topics/obesity/en/> Acesso em: 22 fev.2015.

WU, J. J. et al. Differential effects of nonylphenol on testosterone secretion in rat Leydig cells. Reprod Biol Endocrinol, v. 268, n. 1-2, p. 1-7, 2010.

$\mathrm{XU}, \mathrm{H}$. et al. Chronic inflammation in fat plays a crucial role in the development of obesity-related insulin resistance. In: (Ed.). J Clin Invest. United States, v.112, p.1821-30, 2003.

YAN, Z. et al. Prenatal polycyclic aromatic hydrocarbon, adiposity, peroxisome proliferator-activated receptor (PPAR) gamma methylation in offspring, grand-offspring mice. In: (Ed.). PLoS One. United States, v.9, 2014.

YANG, O. et al. Endocrine-disrupting Chemicals: Review of Toxicological Mechanisms Using Molecular Pathway Analysis. J Cancer Prev. v. 20, p. 12-24, 2015.Review.

YKI-JÄRVINEN, H. Thiazolidinediones. N Engl J Med. v.351, p. 1106-18, 2004. Review.

ZHANG, H. Y.et al. Perinatal exposure to 4-nonylphenol affects adipogenesis in first and second generation rats offspring. v. 225, n. 2, p. 325-32, 2014.

ZHANG, Y. et al. Positional cloning of the mouse obese gene and its human homologue. Nature, v. 372, n. 6505, p. 425-32, 1994.

ZOETE, V.; GROSDIDIER, A.; MICHIELIN, O. Peroxisome proliferator-activated receptor structures: ligand specificity, molecular switch and interactions with regulators. In: (Ed.). Biochim Biophys Acta. Netherlands, v.1771, p.915-25, 2007.

ZOELLER, R.T. et al.Endocrine-disrupting chemicals and public health protection: a statement of principles from The Endocrine Society. Endocrinology. v.153, p. 4097-110, 2012. 